\title{
EVALUASI FUNGSI EKOLOGIS POHON PADA RTH LANSKAP PERMUKIMAN SENTUL CITY, BOGOR (Studi Kasus: Cluster Bukit Golf Hijau)
}

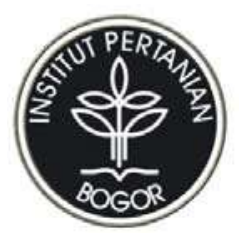

\author{
DEPARTEMEN ARSITEKTUR LANSKAP \\ FAKULTAS PERTANIAN \\ INSTITUT PERTANIAN BOGOR




\title{
PERNYATAAN MENGENAI SKRIPSI DAN SUMBER INFORMASI
}

\section{Dengan ini, saya menyatakan bahwa skripsi yang berjudul}

Evaluasi Fungsi Ekologis Pohon pada RTH Lanskap Permukiman Sentul City, Bogor (Studi Kasus: Cluster Bukit Golf Hijau)

adalah benar merupakan hasil karya sendiri dan belum diajukan dalam bentuk apapun kepada perguruan tinggi manapun. Semua sumber data dan informasi baik yang berasal atau dikutip dari karya yang diterbitkan maupun yang tidak diterbitkan dari penulis lain, telah disebutkan dalam teks dan dicantumkan pada “Daftar Pustaka” skripsi ini.

\author{
Bogor, Februari 2011
}

CHANDRA NURNOVITA

A44060302 


\title{
EVALUASI FUNGSI EKOLOGIS POHON PADA RTH LANSKAP PERMUKIMAN SENTUL CITY, BOGOR \\ (Studi Kasus: Cluster Bukit Golf Hijau)
}

Skripsi

sebagai salah satu syarat untuk memperoleh gelar

Sarjana Pertanian pada

Departemen Arsitektur Lanskap

\author{
DEPARTEMEN ARSITEKTUR LANSKAP \\ FAKULTAS PERTANIAN \\ INSTITUT PERTANIAN BOGOR




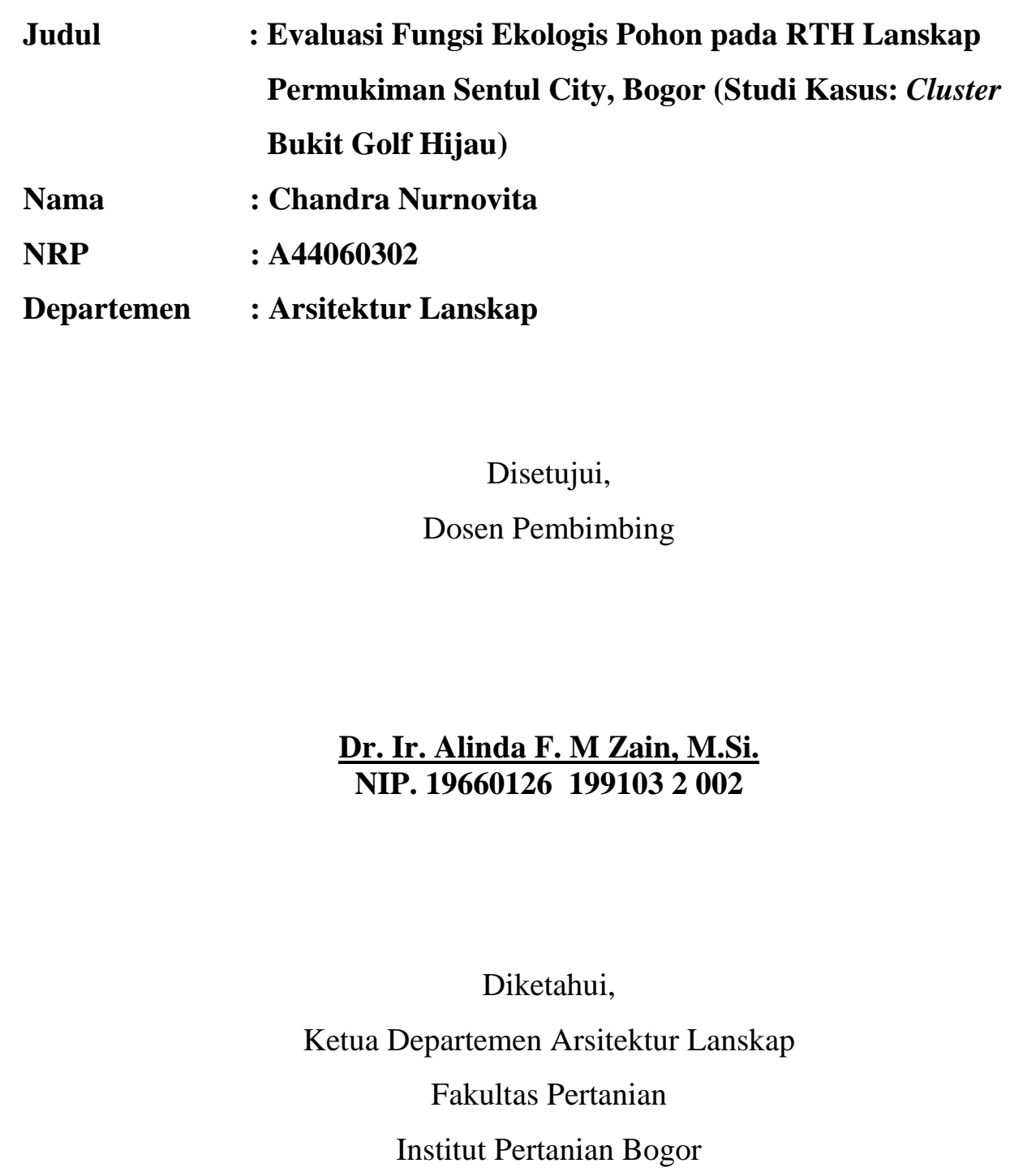

(C)

Dr. Ir. Alinda F. M Zain, M.Si. NIP. 196601261991032002

Dr. Ir. Siti Nurisjah, MSLA

NIP. 194809121974122001

Tanggal disetujui: 


\section{RINGKASAN}

\section{CHANDRA NURNOVITA. Evaluasi Fungsi Ekologis Pohon pada RTH Lanskap Permukiman Sentul City, Bogor (Studi Kasus: Cluster Bukit Golf Hijau). Dibimbing oleh ALINDA F. M ZAIN.}

Sentul City merupakan salah satu kota satelit yang sudah berkembang sebagai kawasan permukiman layak huni dengan luas \pm 3.000 ha dan memiliki penduduk yang umumnya peralihan dari kota-kota besar disekitarnya yaitu kota Jakarta dan kota Bogor. Kota satelit ini dikembangkan oleh PT Sentul City Tbk sejak tahun 1993, berada pada 8 wilayah Desa dan 2 Kecamatan lalu dikelilingi oleh 7 gunung dan dilalui oleh 4 sungai. Salah satu tata guna lahan dari Sentul City ini adalah lanskap permukimannya dimana didalamnya merupakan ruang terbuka hijau untuk mendukung kebutuhan dan aktivitas penghuninya

Penelitian dilakukan di cluster Bukit Golf Hijau Sentul City. Cluster ini berada di Desa Cijayanti. Penelitian dilaksanakan mulai bulan Februari hingga Juli 2010. Penelitian dilakukan dengan menggunakan metode deskriptif yang kemudian dispasialkan dengan menggunakan teknik GIS. Pengumpulan data dilakukan dengan cara pengamatan dan pemetaan di lapang, wawancara pihak terkait, perhitungan, dan studi literatur. Data yang dikumpulkan terdiri dari aspek fisik dan biofisik, iklim, sosial, tata guna lahan dan studi pustaka atau literatur. Tahapan-tahapan yang dilakukan saat penelitian meliputi tahap persiapan, tahap inventarisasi, tahap analisis, tahap penilaian dan evaluasi (aspek fungsi ekologis peredam kebisingan, modifikasi suhu (peneduh), kontrol kelembaban udara, dan penahan angin) berupa deskriptif dan spasial (GIS), dan terakhir tahap perumusan rekomendasi.

Berdasarkan hasil analisis, cluster Bukit Golf Hijau memiliki 4 jenis RTH yang menyebar di 5 area, yaitu RTH di kavling kosong, RTH di area yang khusus untuk kawasan RTH, Pocket Park (taman lingkungan), dan RTH di sepanjang jalan lingkungan. Dari kegiatan pemetaan di lapang, diketahui di RTH cluster Bukit Golf Hijau terdapat 1.163 pohon dengan 38 jenis pohon yang ada. Berdasarkan dari wawancara kepada penghuni, RTH ini sudah mencukupi dan sangat beragam, tetapi RTH ini kurang dimanfaatkan untuk aktivitas penghuni sendiri. Berdasarkan hasil perbandingan fungsi ekologis peredam kebisingan dari studi literatur, KepMNLH No. KEP-48/MENLH/11/1996 (55 dBA) dan Kep829/MENKES /SK/VII/1999 (45-55 dBA), Cluster Bukit Golf Hijau memiliki tingkat kebisingan yang melebihi baku mutu studi literatur yaitu 55,2-62,4 dBA. Berdasarkan hasil perbandingan fungsi ekologis modifikasi suhu (peneduh) dari studi literatur, Bianpoen et al. (1989) $\left(25,6-26,7^{\circ} \mathrm{C}\right)$, Laurie $(1986)\left(27-28^{\circ} \mathrm{C}\right)$ dan Kep-829/MENKES /SK/VII/1999 (18-30 $\left.{ }^{\circ} \mathrm{C}\right)$, Cluster Bukit Golf Hijau memiliki suhu yang berada di daerah nyaman standar literatur yaitu $29,4^{\circ} \mathrm{C}$. Dari ke 5 area disana, yang sudah sesuai dengan standar berada di area lembah, BGH Raya, dan gunung. Berdasarkan hasil perbandingan fungsi ekologis kelembaban udara (dari studi literatur, Laurie (1986) (40-75\%), Bianpoen et al. (1989) (45-50\%), dan Kep-829/MENKES /SK/VII/1999 (40-70\%), Cluster Bukit Golf Hijau memiliki RH (kelembaban udara) yang melebihi standar yaitu 76,4\%. Berdasarkan hasil perbandingan fungsi ekologis penahan angin dari studi literatur (skala Beaufort), 
Cluster Bukit Golf Hijau termasuk dalam skala 1 dengan kecepatan angin berkisar 1-3 Knots dengan tingkatan teduh.

Berdasarkan hasil penilaian dan evaluasi, jenis vegetasi yang sudah memenuhi fungsi ekologis peredam kebisingan (kategori sangat baik dan baik) meliputi 19 jenis $(65,52 \%)$ dengan luas sekitar $177.953 \mathrm{~m}^{2}$, sedangkan yang belum memenuhi (kategori kurang baik) meliputi 10 jenis $(34,48 \%)$ dengan luas sekitar $14.567 \mathrm{~m}^{2}$. Dari hasil fungsi ekologis modifikasi suhu (peneduh), jenis vegetasi yang sudah memenuhi (kategori sangat baik dan baik) meliputi 27 jenis $(93,10 \%)$ dengan luas sekitar $190.944 \mathrm{~m}^{2}$, sedangkan yang belum memenuhi (kategori kurang baik dan buruk) meliputi 2 jenis (6,90\%) dengan luas sekitar $1.576 \mathrm{~m}^{2}$. Dari hasil fungsi ekologis kontrol kelembaban udara, jenis vegetasi yang sudah memenuhi (kategori sangat baik dan baik) meliputi 24 jenis (82,76\%) dengan luas sekitar $173.072 \mathrm{~m}^{2}$, sedangkan yang belum memenuhi (kategori kurang baik) meliputi 5 jenis $(17,24 \%)$ dengan luas sekitar $19.448 \mathrm{~m}^{2}$. Dari hasil fungsi ekologis penahan angin, jenis vegetasi yang sudah memenuhi (kategori sangat baik dan baik) meliputi 22 jenis (75,86\%) dengan luas sekitar $164.248 \mathrm{~m}^{2}$, sedangkan yang belum memenuhi (kategori kurang baik dan buruk) meliputi 7 jenis $(24,14 \%)$ dengan luas sekitar $28.272 \mathrm{~m}^{2}$. Setelah diketahui penilaian dan evaluasi dari masing-masing fungsi ekologis, maka muncul suatu rekomendasi secara deskriptif dalam memberikan kontribusi positif bagi penghuni dan lingkungan cluster Bukit Golf Hijau.

Kata Kunci: Fungsi Ekologis, Lanskap Permukiman, GIS, Rekomendasi. 


\section{RIWAYAT HIDUP}

Penulis dilahirkan di Jambi pada tanggal 08 November 1988, merupakan anak pertama dari dua bersaudara dalam keluarga $H$. Ir. Wibisana Kusumasumantri dan $\mathrm{Hj}$. Sophie Yavebriati.

Pendidikan awal penulis diselesaikan di Taman Kanak-Kanak (TK) di TK Akbar pada tahun 1994. Kemudian pendidkan dasar diselesaikan di SD Negeri Pengadilan IV, Kota Bogor pada tahun 2000. Selanjutnya Pendidikan menengah diselesaikan di SLTP Negeri 4 Kota Bogor pada tahun 2003 dan SMU Negeri 1 Kota Bogor pada tahun 2006.

Penulis diterima menjadi mahasiswi Institut Pertanian Bogor melalui jalur USMI pada tahun 2006 sebagai mahasiswa Tingkat Persiapan Bersama (TPB). Kemudian setahun berikutnya, yaitu tahun 2007, penulis diterima sebagai mahasiswi Departemen Arsitektur Lanskap, Fakultas Pertanian.

Selama menjalankan studinya di IPB, penulis juga mengikuti kegiatan di luar akademik, seperti menjadi anggota Himpunan Mahasiswa Arsitektur Lanskap (HIMASKAP). Penulis juga pernah mengikuti lomba dan kompetisi baik di luar akademik seperti mengikuti sayembara Kebon Pisang tahun 2009. Penulis juga aktif dalam mengikuti kepanitiaan dan seminar yang mendukung kegiatan akademis. 
( Hak Cipta Milik IPB, tahun 2011

Hak Cipta dilindungi Undang-undang

Dilarang mengutip sebagian atau seluruh karya tulis ini tanpa mencantumkan atau menyebutkan sumbernya. Pengutipan hanya untuk kepentingan pendidikan, penelitian, penulisan karya ilmiah, penyusunan laporan, penulisan kritik, atau tinjauan suatu masalah, dan pengutipan tersebut tidak merugikan yang wajar IPB.

Dilarang mengumumkan dan memperbanyak sebagian atau seluruh karya tulis dalam bentuk apapun tanpa izin IPB. 


\section{KATA PENGANTAR}

Segala puji dan syukur Penulis ucapkan Kehadirat Allah SWT atas rahmat karunia-Nya, sehingga pelaksanaan dan penyusunan tulisan skripsi dengan judul : Evaluasi Fungsi Ekologis Pohon pada RTH Lanskap Permukiman Sentul City, Bogor (Studi Kasus: Cluster Bukit Golf Hijau) dapat terlaksana dengan baik. Tulisan ini disusun sebagai salah satu syarat untuk memperoleh gelar Sarjana Pertanian pada Fakultas Pertanian di Institut Pertanian Bogor.

Dalam penulisan skripsi ini penulis mengucapkan terima kasih kepada:

1. Papah Wibisana dan Mamah Sophie yang telah memberikan kasih sayangnya sehingga penulis dapat menyelesaikan skripsi ini.

2. Dr. Ir. Alinda Fitriyani M Zain, MSi. yang telah membimbing penulis dalam menyelesaikan skripsi ini.

3. Dr. Ir. Siti Nurisjah, MSLA. sebagai dosen pembimbing akademik selama kuliah.

4. Pimpinan dan karyawan Sentul City terutama Bapak Andrian, Mba Baby, dan Mas Rizki yang telah membantu penulis selama penelitian disana.

5. Kukuh Widodo. Terimakasih banyak untuk kebersamaannya bersama penulis selama ini baik suka dan duka.

6. Teman - teman satu bimbingan skripsi penulis Ami, Muteb, Biji.

7. Wiwiek Dwi Serlan, atas bimbingan dan bantuan kepada penulis selama pekerjaan skripsi.

8. Teman-teman ARL Teng-Tong 43 yang telah menjadi teman baik penulis selama ini. Terimakasih sudah menemani penulis dengan segala kisah yang layak dikenang.

Akhir kata, penulis berharap agar skripsi ini berguna bagi berbagai pihak yang memerlukan. Dan semoga kita selalu dalam limpahan rahmat Allah SWT.

Bogor, Februari 2011

Penulis 


\section{DAFTAR ISI}

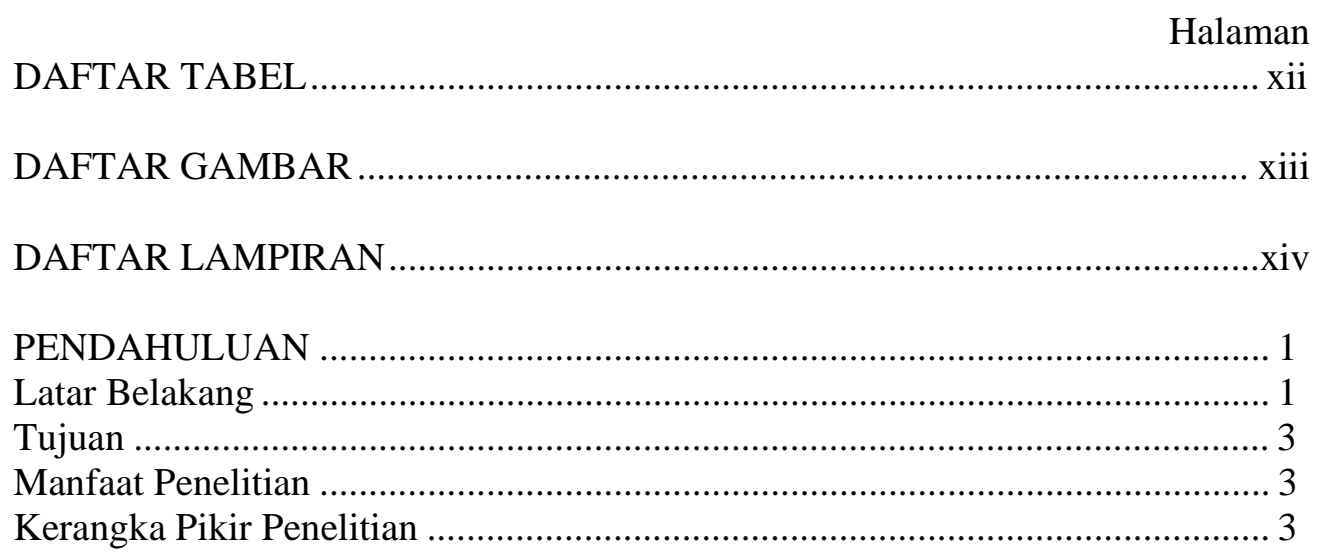

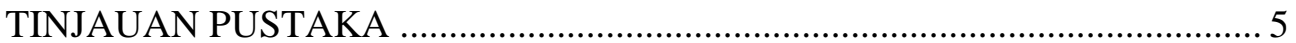

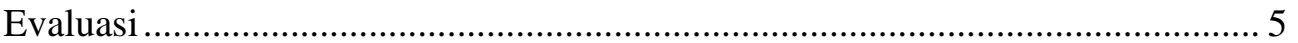

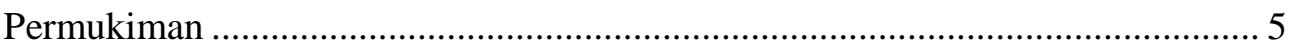

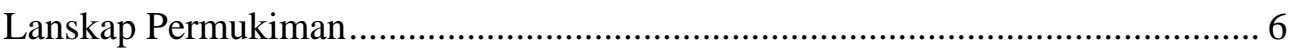

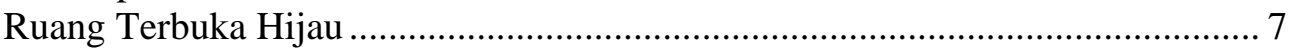

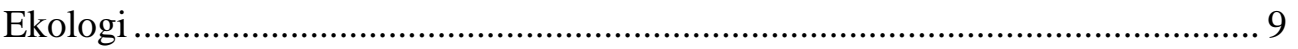

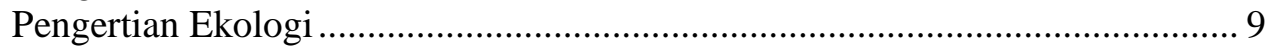

Fungsi dan Manfaat Ekologi .................................................................... 9

Fungsi Ekologis Peredam Kebisingan .............................................................10

Fungsi Ekologis Modifikasi Suhu (Peneduh) …...............................................14

Fungsi Ekologis Kontrol Kelembaban Udara .................................................16

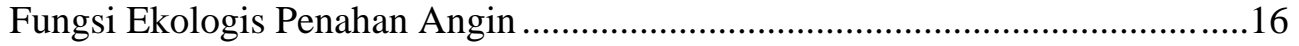

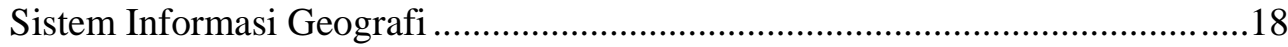

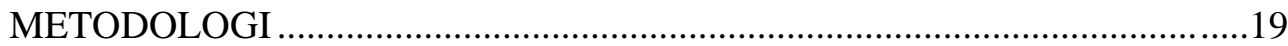

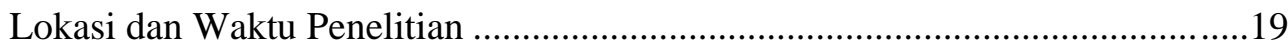

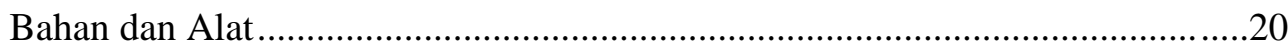

Metode dan Tahapan Penelitian ...................................................................20

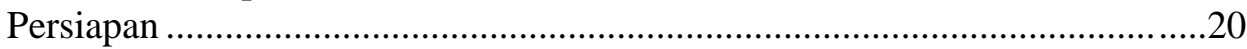

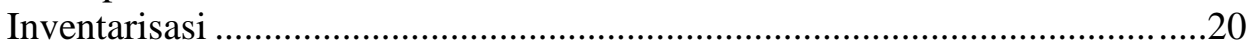

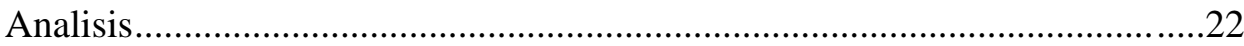

Penilaian Fungsi Ekologis dan Evaluasi ....................................................22

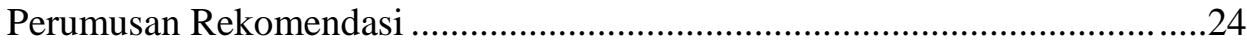

KONDISI UMUM CLUSTER BUKIT GOLF HIJAU SENTUL CITY .............26

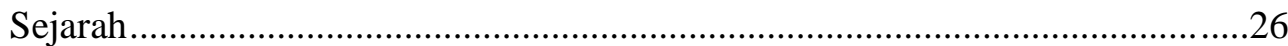

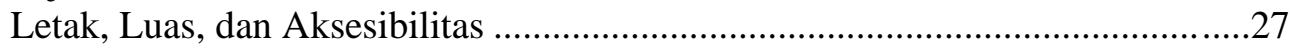

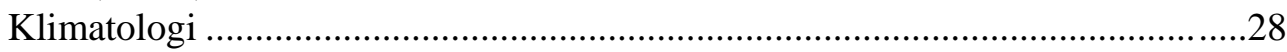

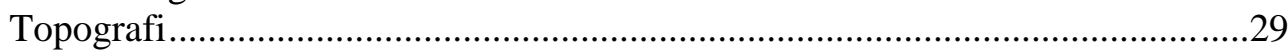

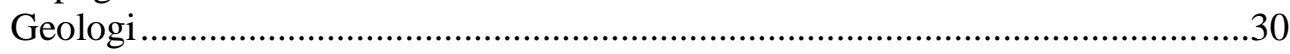

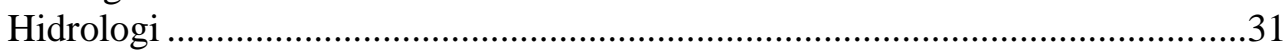

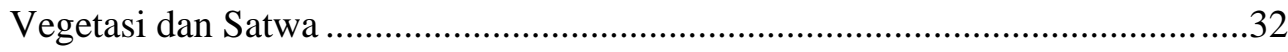

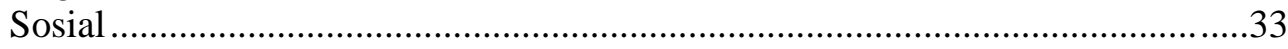

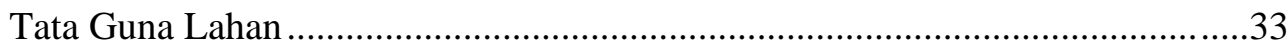




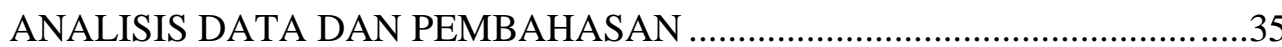

Identifikasi Karakteristik RTH Lanskap Permukiman.......................................35

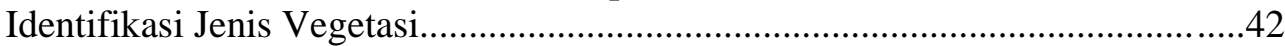

Pengaruh Sosial Terhadap RTH Cluster Bukit Golf Hijau ................................55

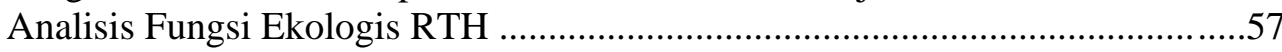

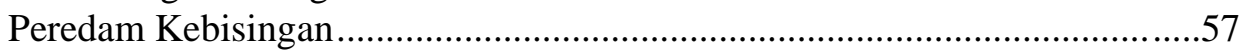

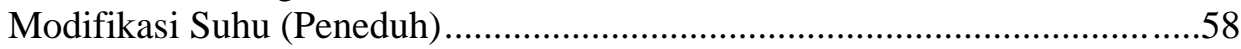

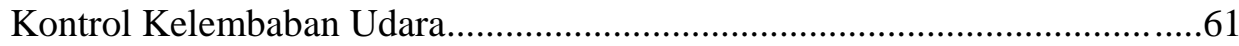

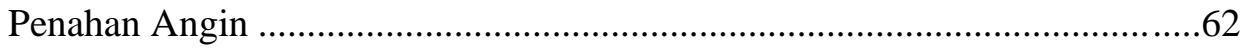

Evaluasi Aspek Fungsi Ekologis Vegetasi RTH Cluster Bukit Golf Hijau.........63

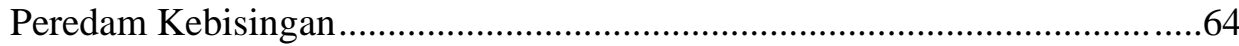

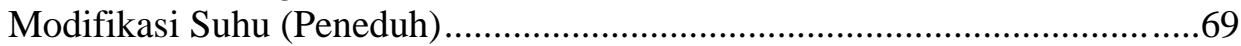

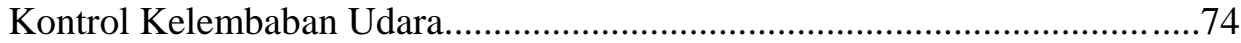

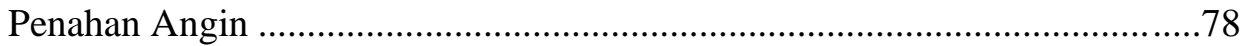

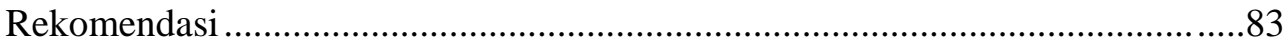

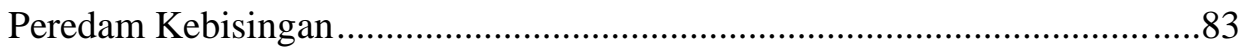

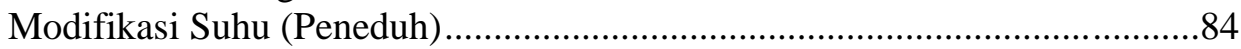

Kontrol kelembaban Udara .....................................................................86

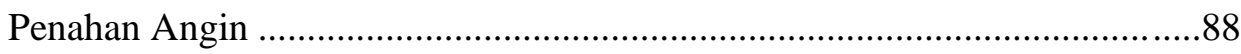

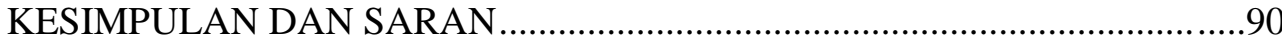

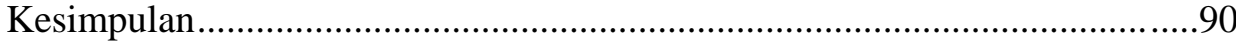

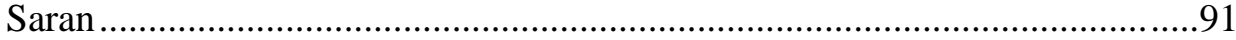

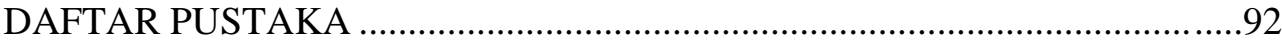

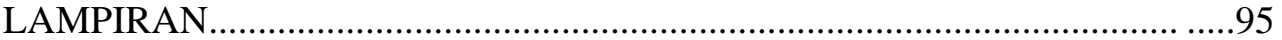




\section{DAFTAR TABEL}

No

Halaman

1. Baku Mutu Tingkat Kebisingan................................................................. 13

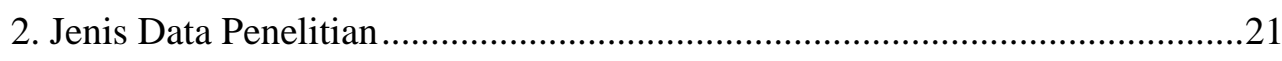

3. Variabel Fungsi Ekologis dan Kriteria Penilaian ........................................ 23

4. Tahap Pekerjaan Penelitian...........................................................................25

5. Perincian Luas lahan di Setiap Desa.........................................................28

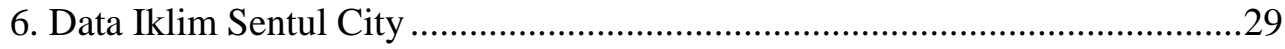

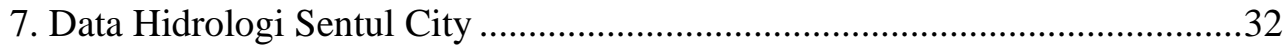

8. Data Tata Guna Lahan Sentul City ..............................................................34

9. Identifikasi Vegetasi Data Sekunder dan Data Primer ..................................42

10. Jenis Vegetasi Khas di Setiap Area Cluster BGH ...................................... 43

11. Baku Mutu Kebisingan Hasil Literatur........................................................ 58

12. Data Suhu Udara Area di Cluster BGH................................................... 59

13. Data Kelembaban Udara Area di Cluster BGH ............................................ 61

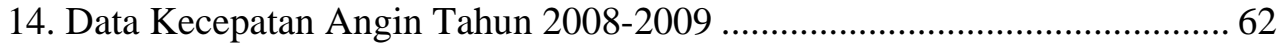

15. Kriteria Penilaian Aspek Fungsi Peredam Kebisingan................................. 64

16. Kriteria Penilaian Aspek Fungsi Modifikasi Suhu (Peneduh)..................... 69

17. Kriteria Penilaian Aspek Fungsi Kontrol Kelembaban Udara...................... 74

18. Kriteria Penilaian Aspek Fungsi Penahan Angin ...................................... 78 


\section{DAFTAR GAMBAR}

No

Halaman

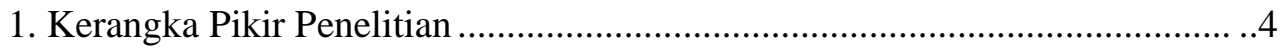

2. Manfaat Tanaman bagi Manusia dalam Kontrol Radiasi ............................. 15

3. Peran Pohon Mengurangi Kecepatan Angin............................................... 17

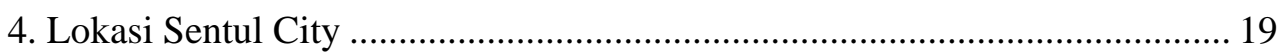

5. Batas-Batas Wilayah Sentul City.............................................................. 27

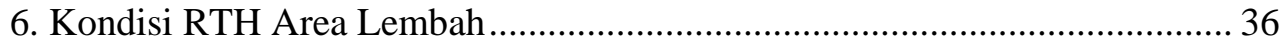

7. Kondisi RTH Area BGH Raya ................................................................. 36

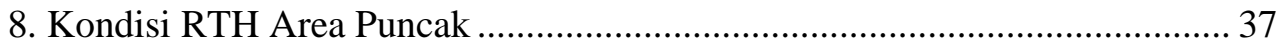

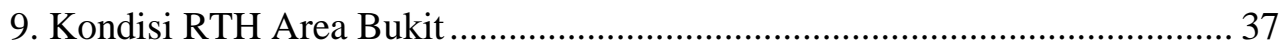

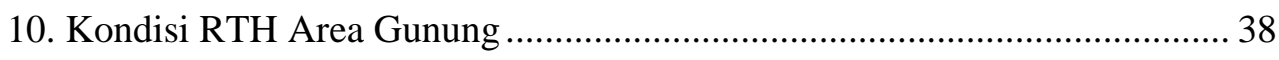

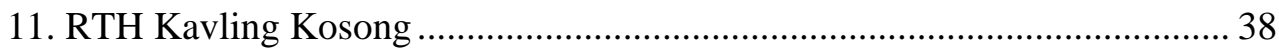

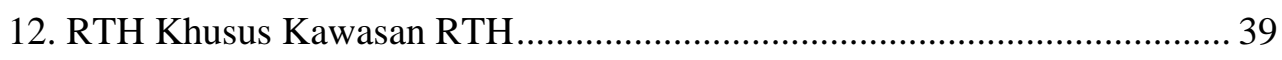

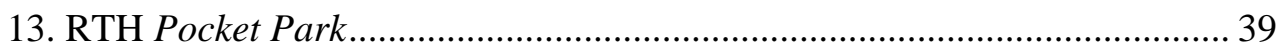

14. RTH di Sepanjang Jalan Lingkungan ........................................................ 40

15. Peta Kawasan Area di Cluster BGH........................................................... 41

16. Identifikasi Jenis Pohon di Cluster BGH (AMDAL 2009) .......................... 53

17. Identifikasi Jenis Pohon di Cluster BGH ................................................. 54

18. Fungsi Vegetasi Mereduksi Bising di Permukiman .................................... 57

19. Keadaan di Darat pada Skala Beaufort 1 ................................................... 63

20. Sebaran Penilaian Vegetasi Peredam Kebisingan ....................................... 68

21. Sebaran Penilaian Vegetasi Modifikasi Suhu............................................. 73

22. Sebaran Penilaian Vegetasi Kontrol Kelembaban Udara ............................ 77

23. Sebaran Penilaian Vegetasi Penahan Angin ................................................ 82

24. Desain Peredam Kebisingan Jalan............................................................. 84

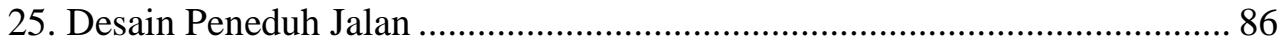

26. Penanaman Pohon Evergreen dan Deciduous .......................................... 89 


\section{DAFTAR LAMPIRAN}

No

Halaman

1. Identifikasi Vegetasi di RTH Cluster BGH (Sumber:AMDAL) .................... 95

2. Identifikasi Vegetasi di RTH Cluster BGH (Sumber: Lapang)..................... 96

3. Data Kriteria Vegetasi di Lokasi Penanaman Berbeda................................101

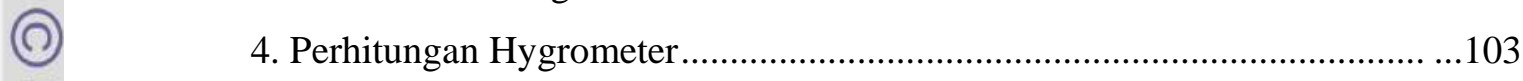

5. Data Suhu, Kelembaban Udara, dan Angin (Januari-Desember 2009) .... ...104

6. Skala Beaufort dan Kecepatan Angin ......................................................105 


\section{PENDAHULUAN}

\section{Latar Belakang}

Berkembangnya suatu kota mengakibatkan semakin banyaknya penduduk di kota tersebut. Hal ini terjadi pada kota-kota besar di Indonesia, terutama di kawasan Jabodetabek. Peningkatan kepadatan penduduk ini menyebabkan semakin meningkatnya permintaan dan kebutuhan tanah untuk permukiman sebagai kebutuhan paling mendasar, sementara itu ketersediaan lahan atau tanah semakin terbatas dan pemerintah tetap mendukung adanya pembangunan permukiman. Kemudian semakin banyak muncul dan dan berkembangnya pembangunan kota-kota baru.

Kota baru sekarang ini disebut dengan kota satelit.. Kota satelit merupakan alternatif permukiman yang dapat menyediakan kelengkapan dan kenyamanan lingkungan permukiman kota lengkap dengan segala fasilitasnya layaknya kota besar (Wikipedia, 2010). Salah satu kota satelit di Indonesia khususnya di kawasan Jabodetabek yaitu Sentul City, Bogor. Sentul City merupakan kawasan permukiman yang sudah layak huni dengan pengembangan dan pengelolaan yang baik dan memiliki konsep sebagai eco city yang mempertimbangkan dampak bagi lingkungan dan meminimalisir pemasukan kebutuhan dari energi. Penduduk Sentul City umumnya peralihan dari kota besar di sekitarnya yaitu Kota Bogor dan Jakarta. Kawasan ini menawarkan beberapa permukiman yang dilengkapi dengan sarana dan prasarana bagi kebutuhan masyarakatnya agar menjadi sebuah kota mandiri. Menurut Simonds (1983), permukiman dinyatakan sebagai kelompok-kelompok rumah yang memiliki ruang terbuka secara bersamaan dan merupakan kelompok yang cukup kecil untuk melibatkan semua anggota keluarga dalam suatu aktivitas, tetapi cukup besar untuk menampung fasilitas umum seperti tempat belanja, lapangan bermain, dan daerah penyangga.

Pengadaan permukiman tersebut diharapkan tidak saja untuk menampung penduduk yang membutuhkan tempat tinggal, tetapi lebih dari itu dapat memberikan kenyamanan penghuni serta keberadaanya tidak merusak lingkungan bahkan menciptakan kondisi lingkungan yang seimbang. Untuk tujuan tersebut, salah satu fasilitas yang perlu disediakan oleh pengembang adalah ruang terbuka 
hijau (RTH) yang merupakan bagian dari lanskap permukiman. RTH di perkotaan khususnya di lingkungan permukiman menjadi penting untuk diadakan mengingat kegiatan manusia di perkotaan yang semakin meningkat telah mendorong munculnya berbagai masalah lingkungan seperti polusi asap kendaraan, penurunan kualitas dan kuantitas air tanah, banjir, dan sebagainya. Masalahmasalah tersebut seterusnya akan berdampak pada masalah lingkungan secara global, yakni peningkatan suhu udara. Sementara ruang hijau dengan vegetasi hijaunya, baik berupa pohon, semak, maupun rumput di ruang terbuka tersebut sebenarnya mempunyai nilai ekologi untuk keseimbangan alam, yaitu dapat mengurangi dampak negatif akibat kegiatan manusia.

RTH lanskap permukiman Sentul City merupakan salah satu sarana dan prasarana fisik untuk menunjang kebutuhan dan aktivitas penghuni dan pengguna. RTH yang dijadikan lokasi penelitian berada di cluster Bukit Golf Hijau. Pemilihan lokasi ini dikarenakan RTH ini merupakan RTH terluas dibandingkan RTH di cluster-cluster lain di Sentul City, selain itu cluster Bukit Golf Hijau juga merupakan cluster pertama yang dibangun di Sentul City. RTH lanskap permukiman harus memperhatikan dua aspek fungsi penting, yaitu fungsi estetika dan fungsi ekologis. Pada fungsi estetika, Sentul City tidak perlu diragukan lagi, karena Sentul City sangat mengutamakan nilai arsitektural dan estetika, misalnya pada pemilihan vegetasi dan desain penanaman, sedangkan pada fungsi ekologis, akan dievaluasi melalui penelitian ini apakah sudah sesuai dengan standar fungsi ekologis RTH permukiman. Pada kawasan ini, hanya beberapa fungsi ekologis yang akan dievaluasi berdasarkan kondisi umum permukiman di Sentul City yaitu fungsi RTH sebagai peredam kebisingan, modifikasi suhu (peneduh), kontrol kelembaban udara, dan penahan angin. Permukiman merupakan suatu kawasan yang digunakan oleh penghuni untuk menghabiskan waktu istirahatnya dari sekian banyaknya rutinitas yang dilakukan, selain itu kebutuhan yang paling mendasar bagi keberlangsungan hidup penduduk. Oleh karena itu perlunya kebutuhan penghuni dalam memperoleh kenyamanan di kawasan permukiman Sentul City. Beberapa fungsi ekologis tersebut merupakan fungsi yang secara langsung dapat dirasakan oleh manusia melalui fisik. Selain itu, berdasarkan Keputusan Menteri Kesehatan No.829/Menkes/SK/VII/1999, bising, kelembaban 
udara, suhu, dan angin merupakan beberapa parameter dalam persyaratan untuk permukiman yang sehat.

Studi evaluasi mengenai fungsi ekologis RTH diperlukan untuk mengetahui kontribusi positif yang diberikan RTH di kawasan permukiman Sentul City. Evaluasi ini juga dilakukan untuk mengetahui sejauh mana RTH ini dapat memenuhi fungsi ekologisnya. Pendekatan evaluasi ini dilakukan untuk mengetahui nilai fungsional dengan cara observasi langsung dan hasil literatur.

\section{Tujuan Penelitian}

Tujuan dari penelitian ini adalah:

1. Mengidentifikasi karakteristik vegetasi dan RTH di lanskap permukiman Sentul City.

2. Menganalisis dan mengevaluasi fungsi ekologis (peredam kebisingan, modifikasi suhu (peneduh), kontrol kelembaban udara, dan penahan angin) di lanskap permukiman Sentul City dengan standar karakteristik vegetasi yang sesuai.

3. Memberikan rekomendasi RTH dengan struktur vegetasi yang sesuai berdasarkan fungsi ekologis (peredam kebisingan, modifikasi suhu (peneduh), kontrol kelembaban udara, dan penahan angin).

\section{Manfaat Penelitian}

Manfaat dari penelitian ini adalah:

1. Memberi masukkan kepada Pengelola Pusat Sentul City dalam penyediaan RTH di lanskap permukiman Sentul City.

2. Memberi masukkan kepada masyarakat atau pengelola permukiman dalam mengelola RTH di lanskap permukiman Sentul City.

\section{Kerangka Pikir Penelitian}

Kepadatan penduduk yang terjadi di kota-kota besar merupakan salah satu alasan terciptanya kota baru atau kota satelit. Salah satu kota satelit yang berada di kawasan Jabodetabek dan sudah layak huni yaitu Sentul City yang memiliki konsep sebagai eco city. Lokasi penelitian berada di cluster Bukit Golf Hijau 
dengan kegiatan penelitian mencangkup lanskap permukiman yang ada. Salah satu bagian dari lanskap permukiman yaitu ruang terbuka hijau yang memiliki fungsi ekologis yang beragam. Pada penelitian ini fungsi ekologis yang diteliti meliputi peredam kebisingan, modifikasi suhu (peneduh), kontrol kelembaban udara, dan penahan angin. Kemudian diberikan kriteria standar setiap fungsinya yang dibandingkan dengan studi pustaka dan literatur melalui penilaian lalu di evaluasi karakteristik vegetasi yang sesuai maupun tidak, dan munculah suatu rekomendasi berupa deskriptif yang diberikan kepada pihak Sentul City (Gambar 1.).

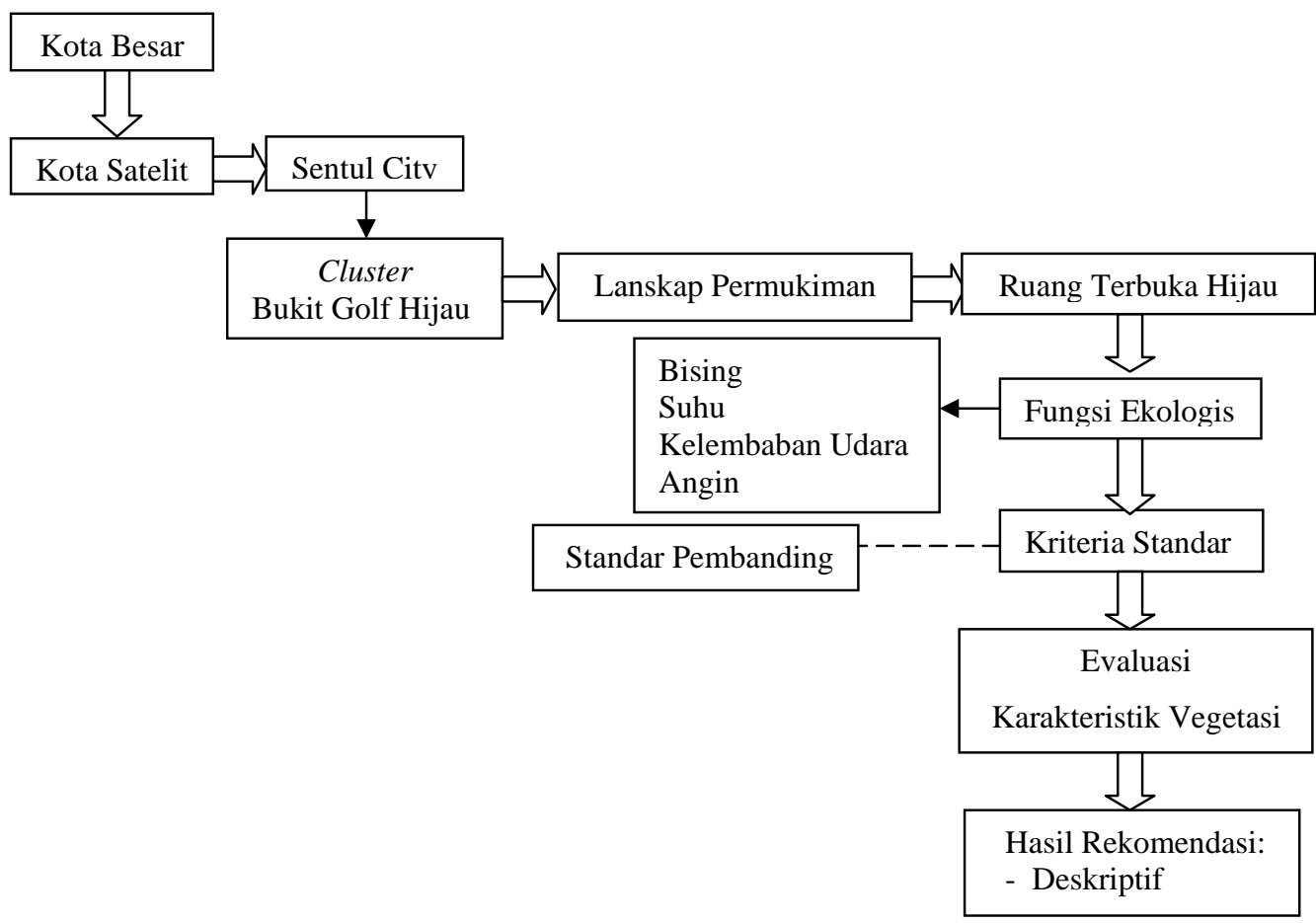

Gambar 1. Kerangka Pikir Penelitian 


\section{TINJAUAN PUSTAKA}

\section{Evaluasi}

Menurut Eliza (1997), evaluasi merupakan suatu tindakan yang dilakukan untuk menelaah atau menduga hal-hal yang sudah diputuskan untuk mengetahui kelemahan dan kelebihan keputusan tersebut. Selanjutnya ditentukan langkahlangkah alternatif perbaikannya bagi kelemahan tersebut.

Evaluasi dilakukan untuk menentukan keputusan apakah akan melanjutkan suatu program yang dinilai sukses atau apakah akan menghentikannya. Tujuan evaluasi adalah untuk mengoleksi dan menampilkan informasi yang diperlukan dalam mendukung pengambilan keputusan dan kesimpulan tentang suatu program serta nilainya Evaluasi ini bertujuan untuk penyeleksian dan menampilkan informasi yang diperlukan dalam mendukung pengambilan kesimpulan dan keputusan tentang suatu program serta nilainya (Echols dan Shadily, 1996).

\section{Permukiman}

Permukiman merupakan sekumpulan rumah yang terpisah di atas petakpetak lahan individual dan sekelompok rumah gandeng, rumah susun, atau apartemen. Ruang terbuka di dalam permukiman terdiri dari beberapa area rekreasi yang juga menyediakan keindahan atau estetika (Laurie, 1986). Menurut Simonds (1983), permukiman dinyatakan sebagai kelompok-kelompok rumah yang memiliki ruang terbuka secara bersamaan dan merupakan kelompok yang cukup kecil untuk melibatkan semua anggota keluarga dalam suatu aktivitas, tetapi cukup besar untuk menampung fasilitas umum seperti tempat belanja, lapangan bermain, dan daerah penyangga.

Menurut UU RI No.04 Tahun 1992, Permukiman adalah bagian dari lingkungan hidup di luar dari kawasan lindung, baik yang berupa kawasan perkotaan maupun pedesaan yang berfungsi sebagai lingkungan tempat tinggal atau lingkungan hunian dan tempat kegiatan yang mendukung perikehidupan dan penghidupan.

Dalam memilih suatu pemukiman terutama untuk pembangunan kota baru harus sesuai dengan tujuan pembangunan fisik, termasuk pemasangan utilitas 
pengadaan permukiman, sistem sirkulasi, berikut dengan fasilitas lingkungan dalam suatu kaitan yang terencana dengan baik dan terbebas dari faktor lingkungan yang tidak diinginkan (Chiara dan Koppelman, 1978).

Eckbo (1964) mengemukakan bahwa lingkungan permukiman yang ideal adalah dengan terdapatnya fasilitas-fasilitas lokal yang tersusun rapi dalam suatu kelompok hunian yang berada pada pusat permukiman, adanya hubungan antar rumah dengan hadirnya pedestrian untuk pejalan kaki, taman yang tersebar secara radial, terdapat akses.

\section{Lanskap Pemukiman}

Laurie (1986) menyatakan bahwa lanskap permukiman adalah perubahan bentuk historis dan situasi, dimana taman dipertahankan dalam wujud rumahnya sendiri sampai wujud lainnya (taman lingkungan) serta permukiman-permukiman ditata dalam suatu lanskap yang lebih luas seperti pembangunan kota-kota baru. Menurut Sukawi (2009), satuan lingkungan permukiman adalah kawasan perumahan dalam berbagai bentuk dan ukuran dengan penataan tanah dan ruang, prasarana dan sarana lingkungan yang terstruktur.

Simonds (1983) menyatakan lingkungan permukiman merupakan pengelompokkan dari beberapa cluster tempat tinggal yang tergabung pada suatu area terbuka dan mempunyai batasan yang jelas dengan fasilitas-fasilitas penunjang seperti pendidikan, niaga, tempat peribadatan, atau fasilitas lainnya. Biasanya fasilitas-fasilitas tersebut diletakkan di luar lanskap hunian, dimana dari tiap hunian dihubungkan dengan adanya jalur hijau dan jalur pejalan kaki. Selanjutnya Simonds (1983) menambahkan bahwa lingkungan hidup yang ideal bagi manusia adalah dimana tegangan (friksi) dapat dihindarkan atau dipecahkan, sehingga dicapai perkembangan optimum dalam hubungan harmonis antara manusia dengan Tuhan, manusia dengan alam, maupun manusia dengan lainnya. Lingkungan permukiman yang ideal merupakan suatu lanskap lingkungan ketetanggaan (neighbourhood) yang memiliki fasilitas taman, bersama-sama membentuk sebuah blok permukiman.

Lingkungan permukiman adalah suatu area yang di dalamnya terdapat susunan ketetanggaan atau kumpulan tempat tinggal dan sarana perkantoran, 
niaga, pendidikan, budaya, kesehatan, dan fasilitas administrasi penting lainnya di sekitar area tersebut, kehadiran fasilitas penunjang yang tersusun rapi disuatu kelompok hunian (cluster) (Eckbo, 1964).

\section{Ruang Terbuka Hijau}

Ruang terbuka dalam lingkungan hidup adalah lingkungan alam dan manusia. Ruang terbuka ini dikelompokkan menjadi tiga, yaitu (a) ruang terbuka untuk kesehatan, kenyamanan, antara lain untuk melindungi kualitas air, pengaturan pembuangan air dan sampah, rekreasi, taman lingkungan, taman kota, (b) ruang terbuka sebagai perlindungan, misanya cagar alam, daerah budaya dan sejarah, (c) ruang terbuka sebagai sumber produksi, yaitu antara lain perhutanan, produksi mineral, peternakan, pengairan, dan lain-lain (Laurie, 1986).

Menurut Sukawi (2009), RTH perkotaan adalah bagian dari ruang-ruang terbuka (open spaces) suatu wilayah perkotaan yang diisi oleh tumbuhan, tanaman dan tanaman (endemik maupun introduksi) guna mendukung manfaat ekologis, sosial-budaya dan arsitektural yang dapat memberikan manfaat ekonomi (kesejahteraan) bagi masyarakatnya. Secara fisik RTH dapat dibedakan menjadi RTH alami yang berupa habitat liar alami, kawasan lindung dan taman-taman nasional, maupun RTH non-alami atau binaan yang seperti taman, lapangan olah raga, dan kebun bunga.

Menurut Peraturan Menteri Dalam Negeri No. 01 Tahun 2007, memilki beberapa definisi terkait RTH yakni:

1. Ruang terbuka adalah ruang-ruang dalam kota atau wilayah yang Iebih luas baik dalam bentuk area/ kawasan maupun dalam bentuk area memanjang jalur di mana dalam penggunaannya lebih bersifat terbuka yang pada dasarnya tanpa bangunan.

2. Ruang Terbuka Hijau Kawasan Perkotaan yang selanjutnya disingkat RTHKP adalah bagian dari ruang terbuka suatu kawasan perkotaan yang diisi oleh tumbuhan dan tanaman guna mendukung manfaat ekologi, sosial, budaya, ekonomi dan estetika. Selain itu jumlah RTH di setiap kota harus sebesar 30\% dari luas kota tersebut. 
Nurisjah dan Pramukanto (1995) mengemukakan RTH dapat berfungsi sebagai tempat rekreasi, olahraga, bersosialisasi dan untuk melepaskan kejenuhan serta kemonotonan kerja. Secara ekologis, RTH dapat berfungsi untuk menciptakan iklim mikro (suplai oksigen, memperbaiki kualitas udara dan suplai air bersih), konservasi tanah dan air serta pelestarian habitat satwa. RTH merupakan ruang fungsional bagi suatu wilayah perkotaan, terutama karena fungsi serta manfaatnya yang tinggi dalam memperbaiki dan meningkatkan kualitas lingkungan.

Menururt Carpenter et al. (1975) dan Simonds (1983) RTH memiliki fungsi utama yaitu untuk kelangsungan fungsi ekologi (penjaga keseimbangan ekosistem kota), untuk berjalannya fungsi kota yang sehat dan wajar (ketersediaan air bersih, udara segar, suhu nyaman) serta untuk meningkatkan karakter dan kualitas lingkungannya seperti keindahan dan pelembut arsitektur kota. Menurut Simonds (1983), RTH di dalam kota dapat menyumbangkan keindahan visual, ruang bernafas yang segar, serta dapat berfungsi sebagai sumber inspirasi dan stimulasi penghuni kota. Manusia yang tinggal di lingkungan perkotaan menbutuhkan suatu lingkungan yang sehat dan bebas polusi untuk hidup dengan nyaman. Disini peran RTH adalah sebagai penyumbang keindahan dan kehidupan satwa, ruang bernafas yang segar, sebagai paru-paru kota, sumber air dalam tanah, menciptakan iklim sebagai unsur pendidikan. Manusia membutuhkan suatu lingkungan yang aman dan nyaman di tengah-tengah lingkungan tempat tinggalnya sehingga manusia di dalam kehidupannya tidak terlepas dari alam. Sementara itu, menurut Carpenter et al. (1975), Ruang Terbuka Hijau berfungsi sebagai pelembut suasana keras dari sruktur fisik, menolong manusia mengatasi tekanan-tekanan dari kebisingan, udara panas, dan polusi disekitarnya serta sebagai pembentuk kesatuan ruang. Selain itu RTH juga adalah suatu sistem ruang terbuka untuk peningkatan pengetahuan dan apresiasi warga kota terhadap lingkungan dan untuk mendapatkan kesenangan dan rekreasi bagi warga kotanya; seimbang dengan berbagai fasilitas pelayanan kota lainnya (Margaretha, 2007).

Keberadaan ruang terbuka hijau di lingkungan perumahan dan kota sangat penting, baik bagi penduduk maupun lingkungan, karena ruang hijau mempunyai berbagai fungsi atau manfaat, seperti ruang untuk kegiatan rekreasi, mengurangi 
polusi udara dan suara, mempengaruhi cuaca setempat, serta manfaat psikologis dan estetika. Selanjutnya ruang terbuka hijau mengandung beberapa nilai, yang mana nilai-nilai tersebut diaktualisasikan dalam hubungan manusia dengan alam. Dari berbagai fungsi, nilai dari ruang terbuka hijau dapat diklasifikasikan menjadi empat kategori, yaitu: nilai ekologis dan alam, nilai sosial dan budaya, nilai psikologis, dan nilai estetika atau keindahan (Bradley dan Milward, 1984).

\section{Ekologi}

\section{Pengertian Ekologi}

Ekologi didefinisikan sebagai pengkajian hubungan organisme atau kelompok organisme terhadap lingkungannya (Odum, 1993). Menurut Resosoedarmo (1992), ekologi dalam pemahaman kuantitatif masih baru. Umpamanya jumlah sinar matahari, jumlah air dan luasan tanah yang dibutuhkan oleh spesies binaan tertentu. Selanjutnya Ia mengatakan ekologi pola baru bukan mencari pola kehidupan secara kuantitatif tetapi juga berusaha mencari jawaban atas masalah kualitatif.

Menurut Gold (1980) pendekatan ekologi merupakan penilaian karakteristik ekologi melalui serangkaian analisis terhadap faktor-faktor ekologi serta hubungan di antara faktor-faktor tersebut. Penjelasan tentang kondisi setiap faktor dan hubungan di antaranya dapat digunakan untuk penjelasan kondisi ekologinya. Secara umum faktor-faktor ekologi tersebut terbagi dalam tiga sumber daya tapak yang paling dasar, yaitu :

1. Lingkungan atmosfer yang terdiri dari udara, uap air, dan mikroorganisme.

2. Lingkungan air yang terdiri dari air, tumbuhan, binatang, mikroorganisme.

3. Lingkungan tanah yang terdiri dari tanah, tumbuhan, binatang, mikroorganisme, dan habitat.

\section{Fungsi dan Manfaat Ekologi}

Setyaningrum (2001) mengungkapkan bahwa perkembangan kota-kota menurut sejarahnya tidak hanya menggambarkan pentingnya keberadaan manusia tetapi juga hubungan antara manusia dan alam. Saat ini proses adaptasi manusia 
terhadap lingkungan sekitarnya harus menempatkan aspek ekologis sebagai pusat untuk mendiskusikan lingkungan.

Fungsi Ekologis, merupakan fungsi ruang terbuka hijau yang memberikan perlindungan terhadap manusia dan lingkungannya dalam Eckbo (1964), terdiri dari;

- Fungsi orologis. Memberikan manfaat orologis yang penting untuk mengurangi tingkat kerusakan tanah, terutama longsor, dan menjaga kestabilan tanah.

- Fungsi hidrologis. Fungsi ini berkaitan dengan kemampuan tanaman untuk menyerap kelebihan air.

- Fungsi klimatologis. Menekankan bahwa fungsi ruang terbuka hijau dapat mempengaruhi faktor-faktor iklim.

- Fungsi edhapis. Fungsi lebih mengarah pada penyediaan habitat satwa perkotaan.

- Fungsi hygienis. RTH mampu memberikan lingkungan yang lebih sehat bagi manusia.

- Fungsi kesehatan individu. Fungsi kesehatan masih berhubungan erat dengan manfaat hygienis, dimana manfaat ini merupakan manfaat lanjutan yang ditimbulkannya.

Menurut Sukawi (2009) secara ekologis RTH dapat meningkatkan kualitas air tanah, mencegah banjir, mengurangi polusi udara, dan menurunkan temperatur kota. Bentuk-bentuk RTH perkotaan yang berfungsi ekologis antara lain seperti sabuk hijau kota, hutan kota, taman botani, sempadan sungai.

\section{Fungsi Ekologis Peredam Kebisingan}

Kebisingan yaitu bunyi yang tidak diinginkan dari usaha atau kegiatan dalam tingkat dan waktu tertentu yang dapat menimbulkan gangguan kesehatan manusia dan kenyamanan lingkungan (KEP-48/MENLH/11/1996) atau semua suara yang tidak dikehendaki yang bersumber dari alat-alat proses produksi dan atau alat-alat kerja pada tingkat tertentu dapat menimbulkan gangguan pendengaran. Bising -suara yang tidak diinginkan- telah menjadi masalah keprihatinan yang meningkat lingkungan luar manusia berhubungan dengan urbansisasi dan teknologi. Menurut Thompson dan Sorvig (2008), kebisingan 
memiliki efek fisiologis dan psikologis pada sesuatu yang hidup, kebisingan yang terus-menerus tidaklah sehat.

Dalam Dahlan (1992), berbagai kegiatan yang ada di kota seperti industri dan kendaraan bermotor dapat menghasilkan kebisingan. Kebisingan dapat menggangggu keheningan dan kenyamanan. Oleh sebab itu, kebisingan perlu dikurangi. Jika saat ini kebisingan sudah sangat menganggu daerah permukiman, rumah sakit, perkantoran, perdagangan, dan pendidikan, maka perlu dibangun jalur hijau yang menyekat sumber kebisingan dengan daerah yang akan dilindungi. Menurut Keputusan Menteri Tenaga Kerja Nomor 51 Tahun 1999, Agar kebisingan tidak mengganggu kesehatan atau membahayakan perlu diambil tindakan seperti penggunaan peredam pada sumber bising, penyekatan, pemindahan, pemeliharaan, penanaman pohon, Secara umum tanaman paling efektif digunakan untuk mengurangi kebisingan dengan frekuensi tinggi yang mengganggu (berbahaya).

Laurie (1986) menyatakan setiap jenis tanaman memiliki kemampuan yang berbeda dalam mereduksi kebisingan dan reduksi kebisingan oleh tanaman berbeda tergantung dari ukuran dan kerapatan daun. Laurie (1986) juga menyatakan bahwa penanaman pohon dan semak dapat mengurangi tingkat kebisingan di udara. Pohon dan semak memiliki daya serap yang tinggi terhadap kebisingan. Kebisingan dapat direduksi hingga $10 \mathrm{~dB}$ pada jalur yang tersusun dari pohon yang tinggi dan rimbun. Semakin dekat tanaman ke sumber kebisingan akan semakin efektif fungsinya dalam meredam kebisingan. Tingkat kebisingan yang dapat direduksi oleh tanaman juga dipengaruhi oleh intensitas, frekuensi, dan arah suara selain itu gelombang bunyi yang menyebar di udara akan berkurang setelah diserap oleh udara dan objek-objek lain diantaranya tanaman. (Carpenter et al., 1975).

Penanaman beberapa spesies secara bersamaan lebih efektif dalam mereduksi kebisingan dari penanaman tunggal (Carpenter et al., 1975), karena penanaman satu spesies hanya dapat menangkap suara dengan frekuensi rendah atau tinggi saja, tapi tidak efektif dalam mereduksi suara dengan fekuensi sedang (antara tinggi dan rendah). Chiara dan Koppelman (1978) menyatakan bahwa 
kombinasi dari pepohonan, perdu rendah, dan permukaan penutup akan memberikan pelemahan.

Pohon dapat meredam suara dengan cara mengabsorpsi gelombang suara oleh daun, cabang dan ranting. Jenis tanaman yang paling efektif untuk meredam suara ialah yang mempunyai tajuk yang tebal dengan daun yang rindang. Dengan menanam berbagai jenis tanaman dengan berbagai starta yang cukup rapat dan tinggi akan dapat mengurangi kebisingan, khususnya dari kebisingan yang sumbernya berasal dari bawah Laurie (1986). Selanjutnya Grey dan Deneke (1978) menyatakan bahwa tanaman berdaun tebal, cabang dan batang yang besar dan penanaman yang rapat serta cabang-cabang yang ringan, mudah bergerak sehingga menimbulkan suara merupakan tanaman yang efektif dalam mengontrol kebisingan. Jenis tanaman yang paling efektif untuk meredam suara ialah yang mempunyai tajuk yang tebal dengan daun yang rindang (Grey dan Deneke, 1978).

Tanaman yang efektif mereduksi kebisingan adalah yang memiliki daun yang lebat sepanjang tahun dengan pola daun yang menyebar hingga ke permukaan tanah. Menurut Carpenter et al. (1975), beberapa tanaman dengan lebar 25-50 kaki (7,5-15m) dapat mengurangi suara bising dengan frekuensi tinggi antara 10-20 dB, tapi kurang efektif jika digunakan untuk mereduksi kebisingan dengan frekuensi yang lebih rendah. Ciri-ciri jenis tanaman yang dapat efektif meredam suara (kebisingan), ialah yang mempunyai karakteristik fisik umum di antara ciri-ciri kombinasi bertajuk rapat dan tebal, berdaun ringan serta mempunyai tangkai-tangkai daun.

Menurut Keputusan Menteri Tenaga Kerja Nomor 51 Tahun 1999, Efekitifitas tanaman dalam mengontrol bising tergantung dari tinggi tanaman, kepadatan daun dan lebar penanaman. Widagdo (1998) menjelaskan bahwa kemampuan tanaman mereduksi kebisingan juga dipengaruhi oleh ketebalan dan kelenturan daun, hal ini berkaitan dengan kemudahan daun untuk bergerak karena angin dan energi suara.

Karakteristik dari Departemen Pekerjaan Umum Direktorat Jenderal Bina Marga (1996), ciri-ciri Peredam kebisingan:

- Terdiri dari beberapa lapis tanaman/terdapat kombinasi pohon, perdu, semak 
- Ditanam dekat ke tepi jalan

- Bermassa daun rapat/berdaun tebal

- Terdapat kombinasi dengan dinding peredam suara

- Terdapat variasi tajuk secara vertikal

Dedaunan tanaman dapat menyerap kebisingan sampai 95\%. (Grey dan Deneke, 1978). Carpenter et al. (1975), mengatakan bahwa RTH Kota dengan ukuran ideal (0,4 Ha), mampu meredam 25-80\% kebisingan.

Berdasarkan Keputusan Menteri Kesehatan No.829/Menkes/SK/VII/1999, baku mutu kebisingan yang dianjurkan di permukiman sehat yaitu 45 dBA dengan batas maksimumnya $55 \mathrm{dBA}$ dengan tingkat getaran maksimum $10 \mathrm{~mm} /$ detik. Selain itu, Berdasarkan Keputusan Menteri Negara Lingkungan Hidup No. KEP48/MENLH/11/1996, ditetapkan mengenai Baku Tingkat Kebisingan pada berbagai peruntukan kawasan atau lingkungan kesehatan (Tabel 1.).

Tabel 1. Baku Mutu Tingkat Kebisingan

\begin{tabular}{|c|c|c|}
\hline No. & $\begin{array}{l}\text { Peruntukkan Kawasan/ } \\
\text { Lingkungan Kesehatan }\end{array}$ & Tingkat Kebisingan (dBA) \\
\hline \multirow[t]{13}{*}{ A } & Peruntukkan Kawasan: & \\
\hline & 1. Perumahan dan permukiman & 55 \\
\hline & 2. Perdagangan dan Jasa & 70 \\
\hline & Perkantoran dan Perdagangan & 65 \\
\hline & 4. Ruang Terbuka Hijau & 50 \\
\hline & 5. Industri & 70 \\
\hline & 6. Pemerintahan dan Fasilitas Umum & 60 \\
\hline & 7. Rekreasi & 70 \\
\hline & 8. Khusus: & \\
\hline & Bandar Udara *) & \\
\hline & Stasiun Kereta Api & 60 \\
\hline & Pelabuhan laut & 70 \\
\hline & - $\quad$ Cagar Budaya *) & \\
\hline \multirow[t]{4}{*}{ B } & Lingkungan Kegiatan : & \\
\hline & 1. Rumah Sakit atau sejenisnya & 55 \\
\hline & 2. Sekolah atau sejenisnya & 55 \\
\hline & 3. Tempat Ibadah atau sejenisnya & 55 \\
\hline
\end{tabular}

Keterangan: *) disesuaikan dengan Ketentuan Menteri Perhubungan.

Sumber : KepMNLH No. KEP- 48/MENLH/11/1996 


\section{Fungsi Ekologis Modifikasi Suhu (Peneduh)}

Tanaman memiliki efek penting dalam suhu udara. Tanah gundul atau permukaan gelap lainnya menyerap panas cepat, tapi perlindungan tanaman menggambarkan lebih banyak radiasi yang datang dan demikian dengan hebatnya mereduksi tanah yang memanas. Akibatnya, dibawah penuh naungan suhu dari permukaan tanah tetap lebih dingin daripada suhu udara, tapi pada tanpa naungan permukaan tanah akan lebih panas dibandingkan udara. Radiasi matahari memberi pengaruh yang sangat kuat kepada cuaca dan iklim. Siang hari suhu udara relatif makin besar karena bahang pemanas besar.

Menurut Laurie (1986), tanaman akan efektif mengontrol kesilauan bila dilakukan penanaman pohon berdaun tebal, rindang, dan evergreen sehingga dapat memberikan toleransi sebagai fungsi kontrol cahaya. Penggunaan tanaman sebagai peneduh dapat dilakukan dengan penanaman pohon yang tajuknya bersinggungan dan lebar, seperti pohon yang memiliki tajuk horizontal, bulat, dome, atau irregular yang memiliki daun rimbun dan ditanam secara kontinyu (DPU Dirjen Bina Marga, 1996). Pohon dapat berperan sebagai tirai penahan udara dingin dari luar dan mempertahankan udara hangat yang diperoleh sebelumnya hingga suhu udara di bawah pohon tetap nyaman. Menurut Budihardjo (1997), keberadaan ruang terbuka hijau seluas kurang lebih 30 ha. yang dipenuhi pepohonan dapat menurunkan suhu lingkungan kurang lebih $2,5^{\circ} \mathrm{C}$. Pengaruh naungan pepohonan terhadap suhu udara dipengaruhi oleh faktor struktur tanaman seperti kerapatan pengisian tajuk, diameter tajuk, dan tinggi tanaman (Nowak dan McPherson, 1997). Robinette (1983) mengemukakan bahwa area yang ternaungi menerima sedikit energi radiasi matahari dibandingkan dengan area yang terbuka sehingga area ternaungi memiliki suhu yang lebih rendah. Menurut Booth (1983) suhu udara di dalam bayang-bayang kanopi ini dapat lebih rendah $8^{\circ} \mathrm{C}$ daripada ruang terbuka.

Pohon-pohon besar dan sedang dapat juga digunakan pada lanskap untuk memberikan naungan. Ini diinginkan untuk ruang terbuka dan bangunanbangunan pada musim panas ketika suhu dapat menjadi tidak nyaman ketika area secara langsung terekspos sinar matahari (Booth, 1983). Daun pepohonan 
menahan, mencerminkan, mengabsorpsi, dan membawa radiasi matahari (Gambar 2.)

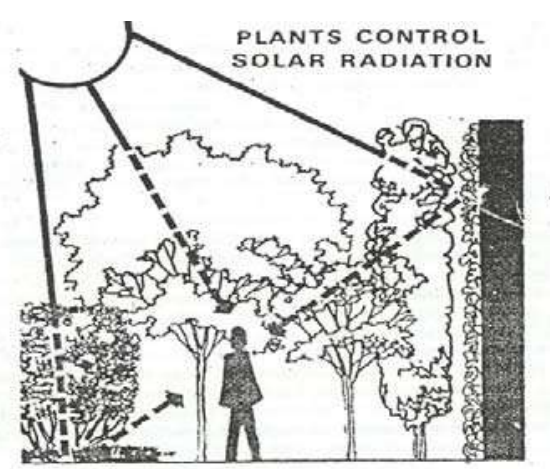

Gambar 2. Manfaat Tanaman bagi Manusia dalam Kontrol Radiasi (Sumber: Grey dan Deneke, 1978)

RTH dapat dibangun untuk mengelola lingkungan perkotaan untuk menurunkan suhu pada waktu siang hari dan sebaliknya pada malam hari dapat lebih hangat karena tajuk pohon dapat menahan radiasi balik (reradiasi) dari bumi. Jumlah pantulan radiasi matahari suatu RTH sangat dipengaruhi oleh panjang gelombang, jenis tanaman, umur tanaman, posisi jatuhnya sinar matahari, keadaan cuaca dan posisi lintang. Suhu udara pada daerah berhutan lebih nyaman daripada daerah yang tidak ditumbuhi oleh tanaman. Pohon dapat memberikan kesejukan pada daerah-daerah kota yang panas (heat island) akibat pantulan panas matahari yang berasal dari gedung-gedung, aspal dan baja. Daerah ini akan menghasilkan suhu udara 3-10 derajat lebih tinggi dibandingkan dengan daerah pedesaan. Penanaman pohon pada suatu areal akan mengurangi temperature atmosfer pada wilayah yang panas tersebut.

Berdasarkan Keputusan Menteri Kesehatan No.829/Menkes/SK/VII/1999, suhu udara yang nyaman bagi lingkungan permukiman sehat yaitu sekitar 18$30^{\circ} \mathrm{C}$. Kemudian menurut Laurie (1986), iklim ideal bagi manusia adalah udara yang bersih dengan suhu antara $27-28^{\circ} \mathrm{C}$. Sedangkan daerah kenyamanan (comfort zone) bagi badan manusia berada pada suhu 25,6-26,7 ${ }^{\circ} \mathrm{C}$ (Bianpoen et al., 1989). 


\section{Fungsi Ekologis Kontrol Kelembaban Udara}

Kelembaban udara adalah kandungan uap air di udara yang dapat dinyatakan sebagai kelembaban, kelembaban nisbi (relatif) maupun defisit tekanan uap air. Tekanan uap jenuh tergantung suhu udara, dimana semakin tinggi suhu udara maka kapasitas untuk menampung uap air dan kelembaban udara kecil. Keterkaitan suhu udara dengan kelembaban udara berhubungan dengan pengembangan dan pengerutan udara. Semakin tinggi suhu udara, kapasitas udara menampung uap air persatuan volume udara juga semakin besar. Oleh sebab itu, pada tekanan uap aktual yang tetap, kelembaban udara (RH) akan lebih kecil bila suhu udara meningkat, dan sebaliknya kelembaban udara semakin tinggi bila suhu udara lebih rendah.

Di Indonesia kelembaban rata-rata harian atau bulanan relatif sepanjang tahun, dengan kelembaban tertinggi pada musim hujan dan terendah pada musim kemarau. Kelembaban yang tinggi merupakan suatu kondisi lingkungan yang tidak nyaman bagi manusia. Kelembaban udara yang ideal dimana manusia dapat beraktivitas dengan nyaman adalah sekitar 40-75\% (Laurie, 1986). Berdasarkan Keputusan Menteri Kesehatan No.829/Menkes/SK/VII/1999, Kelembaban udara yang nyaman bagi lingkungan permukiman sehat yaitu sekitar 40-70\%, Sedangkan relative humidity $(\mathrm{RH})$ daerah kenyamanan (comfort zone) bagi badan manusia adalah 45-50\% (Bianpoen et al.,1989).

Di bawah tajuk kelembaban menjadi tinggi dan evaporasi lebih rendah (Grey dan Deneke, 1978). Udara di bawah kanopi tanaman juga lebih lembab daripada udara diatas permukaan tanpa naungan dan akibatnyalebih panas dibutuhkan untuk menaikkan suhu udara dibawah tanaman.

Kelembaban yang mendekati angka kenyamanan terdapat pada bagian pohon dengan kerapatan daun yang rendah (Bianpoen et al., 1989).

\section{Fungsi Ekologis Penahan Angin}

Robinette (1983) menyatakan bahwa pada daerah yang memiliki banyak tegakan pohon akan memanipulasi kecepatan turbulensi angin dengan cara menghalangi, membelokkan arah dan atau menyaringnya. Vegetasi dan pohon yang berdiri tegak seringkali menjadi pemecah angin atau 'wind break' yang 
memang sengaja direncanakan untuk mengurangi kecepatan angin dengan cara menyaring angin yang melintas sesuai dengan keinginan kita Komposisi tanaman yang berbeda ketinggian mampu mengurangi kecepatan angin sekitar 40-50\% (Carpenter et al., 1975). RTH berfungsi sebagai penahan angin yang mampu mengurangi kecepatan angin 75-80\% (Hakim dan Utomo, 2004).

Pohon mengurangi kecepatan angin dan membuat zona perlindungan menghindari angin. Efek yang lebih besar yaitu dari kerapatan penanaman pohon konifer daripada penanaman pohon deciduous dan semak. Pohon dan semak mengontrol angin dengan halangan, petunjuk, defleksi, dan filtrasi (Grey dan Deneke, 1978). Halangan mempengaruhi peletakan tanaman dalam mengurangi kecepatan angin dengan meningkatkan perlawanan terhadap aliran angin (Gambar 3.)

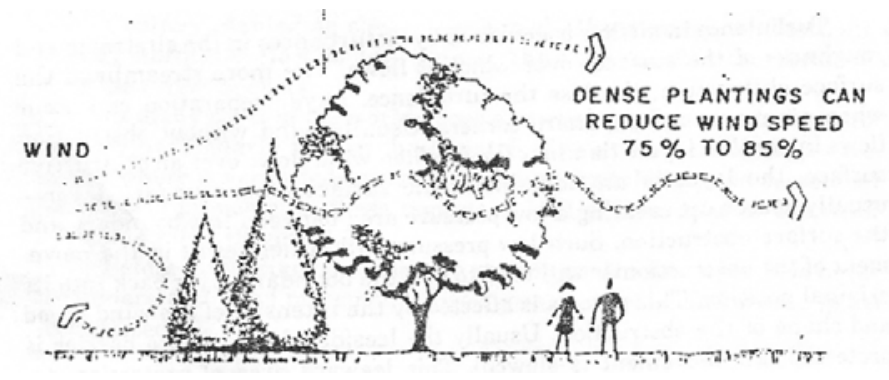

Gambar 3. Peran Pohon Mengurangi Kecepatan Angin (Sumber: Grey dan Deneke, 1978).

Grey dan Deneke (1978) juga menyatakan bahwa tingkat proteksi suatu area oleh angin tergantung pada ketinggian pohon. Angin yang mempunyai arah tegak lurus terhadap deretan tanaman penahan angin gerakannya akan dipengaruhi oleh sampai pada jarak 5-10 kali tinggi tanaman pada ruang dekat pohon sampai 30 kali tinggi tanaman pada bagian belakang.

Beberapa syarat tanaman dapat berfungsi sebagai penahan angin dengan baik menurut Dahlan (1992), adalah:

- Memiliki dahan yang kuat tapi cukup lentur.

- Daunnya tidak mudah gugur oleh terpaan angin agak kuat.

- Tajuk tidak terlalu rapat dan juga tidak terlalu jarang. Tajuk yang terlalu rapat akan mengakibatkan terbentuknya angin turbulen, sedangkan tajuk yang 
terlalu jarang tidak dapat berfungsi sebagai penahan angin. Kerapatan tanaman yang ideal antara 75-85\%.

- Tinggi tanaman harus cukup, agar dapat bekerja sebagai pelindung dengan baik.

\section{Sistem Informasi Geografi}

Dalam Prahasta (2004) , Geographic Information System (GIS) merupakan suatu sistem berbasiskan komputer yang digunakan untuk menyimpan dan menganalisis informasi-informasi geografis. Perangkat lunak dari sistem ini adalah yang memiliki kemampuan untuk memanipulasi dan menganalisa data spasial, secara umum memiliki lima komponen, yaitu:

1. Perangkat untuk mengimpor data

2. Basis data

3. Sistem basis data

4. Perangkat untuk mentransfer dan memanipulasi data

5. Perangkat untuk menyajikan dan mencetak data 


\section{METODOLOGI}

\section{Lokasi dan Waktu Penelitian}

Penelitian ini dilakukan di cluster Bukit Golf Hijau yang berada di dalam Sentul City. Sentul City terletak di Kecamatan Babakan Madang dan Kecamatan Sukaraja Kabupaten Bogor, Provinsi Jawa Barat (Gambar 4.). Penelitian dilaksanakan pada bulan Februari sampai November 2010. Waktu pengumpulan data di lapang selama tiga bulan, yaitu pada bulan Februari sampai Juni 2010 dan pengolahan data dan penyusunan dilakukan selama enam bulan berikutnya.

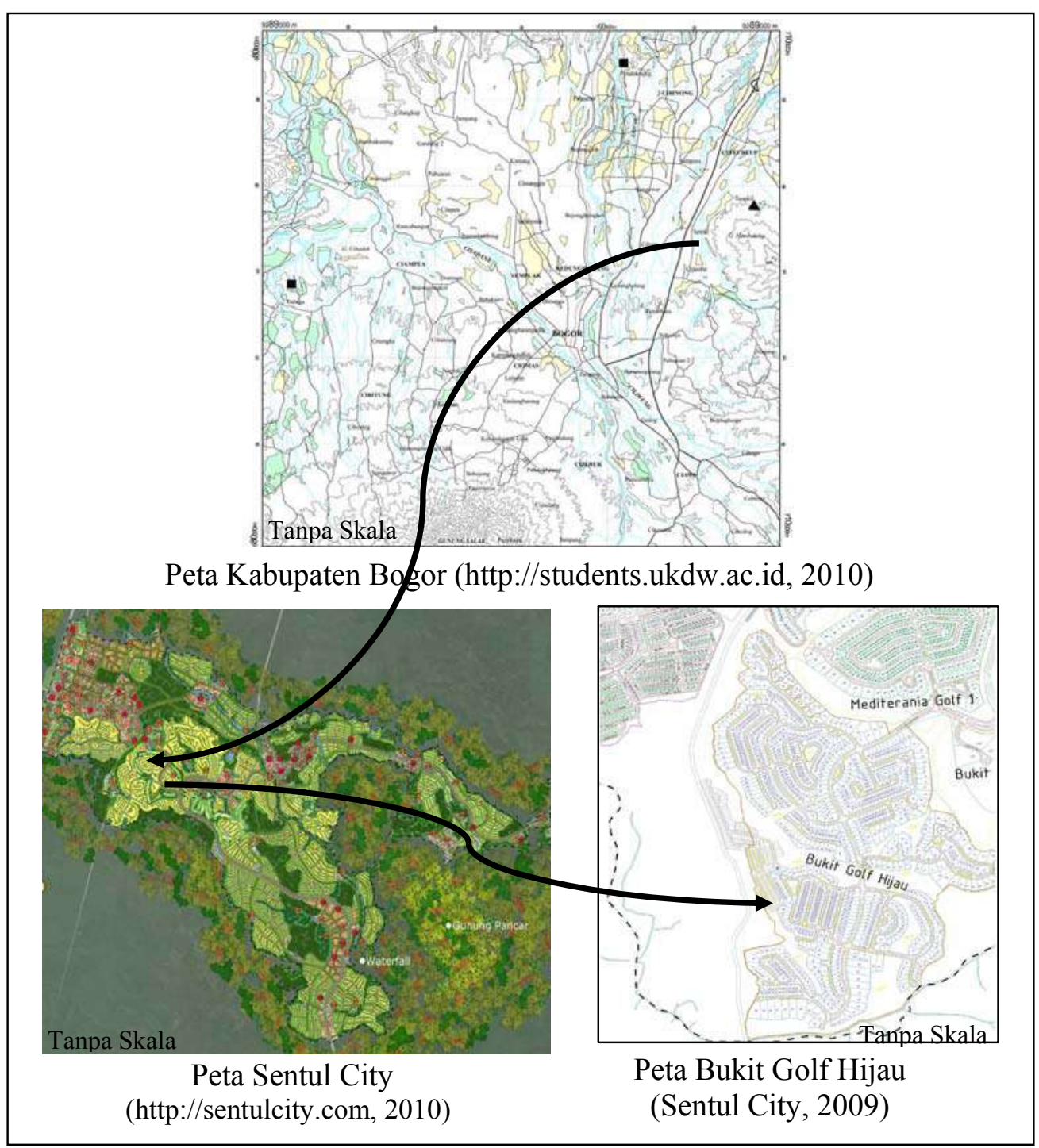

Gambar 4. Lokasi Sentul City 


\section{Bahan dan Alat}

Bahan yang digunakan yaitu :

- Data Fisik dan Biofisik

- Data Tata Guna Lahan

- Data Iklim

- Data Sosial

- $\quad$ Studi Pustaka

- Peta Spasial

Alat yang digunakan yaitu :

- Kamera digital

- $\quad$ GPS (Global Positioning System)

- Kalkulator

- AutoCad 2008, ArcView 3.2, Garmin

- Thermo Hygrometer

- Micrososft Word dan Microsoft Excel

- Laptop

\section{Metode dan Tahapan Penelitian}

Metode yang digunakan pada penelitian ini yaitu deskriptif yang kemudian dispasialkan. Penelitian dilakukan dengan beberapa tahap yaitu persiapan, inventarisasi, analisis, penilaian dan evaluasi, dan rekomendasi (Tabel 4).

\section{Persiapan}

Pada tahap ini kegiatan yang dilakukan berupa penulisan usulan penelitian dan pemilihan lokasi penelitian, konsultasi, pengumpulan data sekunder, pengkajian studi pustaka dan literatur, dan pengurusan izin penelitian. Kegiatan ini belum dilakukan di lokasi penelitian.

\section{Inventarisasi}

Inventarisasi dilakukan untuk mengumpulkan data primer dan data sekunder. Data primer didapatkan dari observasi lapang. Dan data sekunder 
didapatkan dari pihak pengelola Sentul City dan Kantor Pemerintahan. Kegiatan yang dilakukan di lapang berupa identifikasi dan karakteristik RTH cluster Bukit Golf Hijau (BGH) dan pengambilan foto kondisi eksisting lokasi dengan menggunakan alat kamera digital. Kemudian kegiatan pengambilan data suhu dan kelembaban udara RTH cluster BGH menggunakan Thermo Hygrometer. Selanjutnya kegiatan pemetaan terhadap posisi sebaran dan jumlah vegetasi di RTH cluster BGH menggunakan GPS (Global Positioning System), sementara itu dilakukan juga penulisan nama vegetasi dan jumlahnya agar data teridentifikasi yang di GPS dan kegiatan terakhir yaitu wawancara pihak terkait. Dalam penelitian ini jenis vegetasi hanya dibatasi jenis pohon yang sudah berukuran dewasa dengan tinggi sekitar 6-45 m. Semua kegiatan yang dilakukan di lapang merupakan data primer. Adapula pengambilan data sekunder yang berasal dari pengelola dan sumber terkait berupa data aspek fisik dan biofisik, data iklim (kecepatan angin), data baku mutu kebisingan, data sosial, data letak geografis, peta spasial, dan standar fungsi ekologis dari studi literatur (Tabel 2.).

Tabel 2. Jenis Data Penelitian

\begin{tabular}{|c|c|c|c|c|}
\hline No & Jenis Data & Parameter & Bentuk Data & Sumber Data \\
\hline \multirow[t]{3}{*}{1} & Letak Geografis & Batas Wilayah & Sekunder & Pengelola Sentul \\
\hline & & Luas Wilayah & & \\
\hline & & Topografi Wilayah & & \\
\hline 2 & $\begin{array}{l}\text { Tata Guna } \\
\text { Lahan }\end{array}$ & $\begin{array}{l}\text { Pola Penggunaan Lahan } \\
\text { (RTH) }\end{array}$ & Sekunder & $\begin{array}{l}\text { Pengelola Sentul } \\
\text { City }\end{array}$ \\
\hline \multirow[t]{2}{*}{3} & Sosial & Aktivitas & Primer & $\begin{array}{l}\text { Lapang } \\
\text { (Wawancara) }\end{array}$ \\
\hline & & Jumlah Kavling & Sekunder & $\begin{array}{l}\text { Pengelola Sentul } \\
\text { City }\end{array}$ \\
\hline \multirow[t]{4}{*}{4} & Vegetasi & Sebaran Vegetasi & Primer - & Lapang (GPS) - \\
\hline & & Jumlah Vegetasi & Sekunder & Pengelola Sentul \\
\hline & & Jenis Vegetasi & & City \\
\hline & & $\begin{array}{l}\text { Penulisan Nama } \\
\text { Vegetasi }\end{array}$ & Primer & Lapang \\
\hline \multirow[t]{4}{*}{5} & Iklim & Suhu Udara & Primer - & Lapang (Thermo \\
\hline & & & Sekunder & $\begin{array}{l}\text { Hygrometer) - } \\
\text { BMKG }\end{array}$ \\
\hline & & Kelembaban Udara & Primer & $\begin{array}{l}\text { Lapang (Thermo } \\
\text { Hygrometer) }\end{array}$ \\
\hline & & Kecepatan Angin & Sekunder & $\mathrm{BMKG}$ \\
\hline 6 & Kebisingan & Baku Mutu Kebisingan & Sekunder & $\begin{array}{l}\text { Pengelola Sentul } \\
\text { City }\end{array}$ \\
\hline
\end{tabular}


Tabel 2. Lanjutan

\begin{tabular}{lllll}
\hline 7 & $\begin{array}{l}\text { Ruang terbuka } \\
\text { Hijau }\end{array}$ & $\begin{array}{l}\text { Identifikasi } \\
\text { Karakteristik }\end{array}$ & $\begin{array}{l}\text { Primer - } \\
\text { Sekunder }\end{array}$ & $\begin{array}{l}\text { Lapang - } \\
\text { Pengelola Sentul } \\
\text { City) }\end{array}$ \\
\cline { 3 - 5 } & & Foto Eksisting & Primer & Lapang \\
\hline 8 & $\begin{array}{l}\text { Standar Fungsi } \\
\text { Ekologis }\end{array}$ & $\begin{array}{l}\text { Peredam Kebisingan } \\
\text { Modifikasi Suhu } \\
\end{array}$ & Sekunder & $\begin{array}{l}\text { Studi Literatur } \\
\text { (Pustaka dan } \\
\text { (Peneduh) }\end{array}$ \\
& Kontrol Kelembaban & & \\
& Udara & & \\
& & & \\
& & & \\
\hline 9 & Penahan Angin & & $\begin{array}{l}\text { Pnternet - } \\
\text { Peta Spasial }\end{array}$ \\
& Lokasi Penelitian & Sekunder & City \\
\hline
\end{tabular}

Analisis

Analisis yang dilakukan secara deskriptif, yaitu dimana hasil dari inventarisasi RTH cluster BGH di lapang di analisis berupa karakteristik dan identifikasinya. Selain itu analisis deskriptif juga digunakan pada hasil inventarisasi fungsi ekologis RTH yang kemudian dibandingkan dengan studi literatur diantaranya menggunakan perhitungan (Suhu dan Kelembaban udara), dimana akan diketahui apakah kondisi RTH cluster BGH kenyataannya sesuai dengan standar yang berpengaruh terhadapa kenyamanan penghuni yang seharusnya. Dalam tahap ini juga menggunakan teknik GIS untuk mengetahui sebaran vegetasi di RTH cluster BGH yang termasuk dalam analisis identifikasi.

\section{Penilaian Fungsi Ekologis dan Evaluasi}

Tahapan ini dilakukan guna untuk mengetahui secara kualitatif dan kuantitatif keberadaan RTH cluster BGH dengan menyesuaikan kebutuhan kenyamanan penghuni berdasarkan fungsi ekologis peredam kebisingan, modifikasi suhu (peneduh), kontrol kelembaban udara, dan penahan angin.

Teknik penilaian fungsi ekologis RTH dilakukan berdasarkan komponen fungsi ekologis RTH yang ada di lapang dengan perbandingan standar berdasarkan kajian studi pustaka dan literatur. Penilaian aspek fungsi ekologis bertujuan untuk mengetahui secara kuantitatif keberadaan RTH di permukiman dengan menyesuaikan fungsi ekologisnya. 
Penilaian untuk masing-masing kriteria tadi akan dijumlahkan sehingga diperoleh nilai total untuk setiap komponen aspek. Nilai total tersebut kemudian dibandingkan dengan jumlah ideal (total maksimum) yang dapat diperoleh masing-masing komponen aspek dan diubah ke dalam bentuk persen (\%).

$$
\begin{aligned}
& \text { Jumlah masing - masing knitarda perillatan }
\end{aligned}
$$

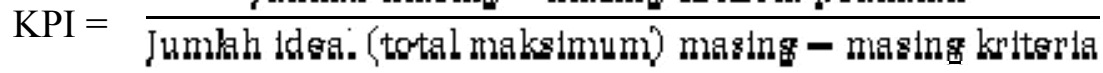

Sehingga total bobot penilaian dapat dikelompokkan ke dalam 4 kategori penilaian akhir untuk masing-masing aspek. Pengelompokkan dilakukan dengan menggunakan 5 selang, dimana nilai-nilai yang membagi bobot sempurna $100 \%$ menjadi 5 bagian sama besar, yaitu masing-masing $20 \%$ tetapi dalam penilaian ini $40 \%$ pembobotan terendah dikelompokkan ke dalam satu kategori (buruk) dengan tujuan untuk menaikkan kriteria standar penilaian (Hidayat, 2008). Berikut persentase pembobotan dengan persyaratan pemenuhan kriteria sebagai berikut :

4: Sangat Baik (bila pemenuhan kriteria $\geq 81 \%$ )

3: Baik (bila pemenuhan kriteria 61-80\%)

2: Kurang Baik (bila pemenuhan kriteria 41-60\%)

1: Buruk (bila pemenuhan kriteria $\leq 40 \%$ )

Pengelompokkan fungsi vegetasi dilakukan dengan menggunakan standar dan dasar penilaian berupa kriteria seperti pada Tabel 3 berikut.

Tabel 3. Variabel Fungsi Ekologis dan Kriteria Penilaian

\begin{tabular}{|c|c|}
\hline Variabel & Kriteria Penilaian \\
\hline \multirow[t]{5}{*}{$\begin{array}{l}\text { Peredam } \\
\text { Kebisingan }\end{array}$} & $\begin{array}{l}\text { 1. Tajuk rapat dan massa daun rapat (DPU Dirjen Bina Marga, } \\
\text { 1996) }\end{array}$ \\
\hline & 2. Berdaun tebal (Grey dan Deneke, 1978) \\
\hline & 3. Struktur cabang dan batang besar (Grey dan Deneke, 1978) \\
\hline & 4. Mempunyai tangkai-tangkai daun (Carpenter, 1975) \\
\hline & 5 Daun rindang dan ringan (Carpenter, 1975) \\
\hline \multirow[t]{5}{*}{ Peneduh } & 1. Pohon relatif tinggi (Booth dan Hiss, 2005) \\
\hline & $\begin{array}{l}\text { 2. Bentuk tajuk spreading, bulat, dome, irregular (DPU Dirjen Bina } \\
\text { Marga, 1996) }\end{array}$ \\
\hline & 3. Bermassa daun padat (DPU Dirjen Bina Marga, 1996) \\
\hline & 4. Berkanopi besar dan lebar (Booth dan Hiss, 2005) \\
\hline & 5. Daun tebal (Carpenter, 1975) \\
\hline
\end{tabular}


Tabel 3. Lanjutan

\begin{tabular}{ll} 
Kelembaban & 1.Kerapatan daun rendah (Bianpoen et al, 1989) \\
Udara & 2. Berdaun jarum atau kasar (Grey dan Deneke, 1978) \\
& 3.Tekstur batang kasar (Grey dan Deneke, 1978) \\
& 4. Jumlah daun banyak (Carpenter, 1975) \\
\hline Penahan Angin & 1. Dahan yang kuat tapi cukup lentur (Dahlan, 1992) \\
& 2.Vegetasi tinggi (Carpenter, 1975) \\
& 3. Daunnya tidak mudah gugur (evergreen) (Dahlan, 1992) \\
& $\begin{array}{l}\text { 4. Tajuk masif dan rindang (YAI dan BAPPEDA DKI, 2001) } \\
\text { 5ermassa daun rapat atau berdaun tebal (DPU Dirjen Bina } \\
\text { Marga, 1996) }\end{array}$ \\
\end{tabular}

Penilaian kriteria fungsi ekologis dilakukan di lapang melalui visual peneliti, oleh karena itu pemilihan setiap kategorinya berdasarkan rata-rata.

Misalnya, kriteria tinggi vegetasi pada setiap pohon kategorinya seperti berikut:

4 : jika ketinggian pohon $>31 \mathrm{~m}$

3 : jika ketinggian pohon 21-30 m

2 : jika ketinggian pohon 11-20 m

1 : jika ketinggian pohon $<10 \mathrm{~m}$

Evaluasi fungsi ekologis RTH permukiman dilakukan untuk mengetahui secara kualitatif dan kuantitatif persentase vegetasi sesuai dan tidak sesuai setiap kategorinya dan jenis vegetasi yang memiliki kesesuaian terhadap masing-masing fungsi ekologisnya. Selain itu penggunaan teknik GIS dalam mengetahui sebaran vegetasi dengan luasan yang sesuai setiap fungsi ekologisnya.

\section{Perumusan Rekomendasi}

Tahap ini merupakan tahap akhir evaluasi yang akan menghasilkan rekomendasi untuk perbaikan aspek fungsi ekologis RTH lanskap permukiman. Rekomendasi diarahkan juga untuk meningkatkan kualitas vegetasi RTH lanskap permukiman berdasarkan analisis data yang telah diperoleh sebagai bahan masukan bagi pengelola Sentul City, Bogor dalam menyusun Rencana Pengelolaan Lingkungan (RKL) di masa yang akan datang. Pada tahap ini hasil keluarannya berupa deskriptif melalui laporan yang akan diberikan kepada pihak pengelola Sentul City. 
Tabel 4. Tahap Pekerjaan Penelitian

\begin{tabular}{|c|c|c|}
\hline No & $\begin{array}{l}\text { Tahapan } \\
\text { Penelitian }\end{array}$ & Keterangan \\
\hline 1 & Persiapan & $\begin{array}{l}\text { Usulan Penelitian, } \\
\text { Lokasi, Konsultasi } \\
\text { Data Sekunder } \\
\text { Studi pustaka dan Literatur } \\
\text { Perizinan }\end{array}$ \\
\hline 2 & Inventarisasi & $\begin{array}{l}\text { Primer: } \\
\text { Identifikasi dan karakteristik RTH } \\
\text { Pengambilan foto kondisi eksisting } \\
\text { Pengambilan data suhu dan kelembaban udara RTH } \\
\text { Pemetaan terhadap posisi sebaran dan jumlah vegetasi } \\
\text { Penulisan nama dan jumlah vegetasi } \\
\text { Wawancara } \\
\text { Sekunder: } \\
\text { Data aspek fisik dan biofisik } \\
\text { Data iklim (kecepatan angin) } \\
\text { Data baku mutu kebisingan } \\
\text { Data sosial, } \\
\text { Data letak geografis, } \\
\text { Peta spasial } \\
\text { Standar fungsi ekologis dari studi literatur } \\
\end{array}$ \\
\hline 3 & Analisis & $\begin{array}{l}\text { - Hasil dari inventarisasi RTH cluster BGH di lapang di } \\
\text { analisis berupa karakteristik dan identifikasinya } \\
\text { - Hasil inventarisasi fungsi ekologis RTH yang kemudian } \\
\text { dibandingkan dengan studi literatur } \\
\text { Teknik GIS untuk mengetahui sebaran vegetasi }\end{array}$ \\
\hline 4 & $\begin{array}{l}\text { Penilaian Fungsi } \\
\text { Ekologis dan } \\
\text { Evaluasi }\end{array}$ & $\begin{array}{l}\text { - Mengetahui secara kualitatif dan kuantitatif keberadaan } \\
\text { RTH cluster BGH dengan menyesuaikan kebutuhan } \\
\text { kenyamanan penghuni } \\
\text { - Penilaian untuk masing-masing kriteria yang } \\
\text { dikelompokkan menjadi } 4 \text { kategori } \\
\text { - Evaluasi persentase vegetasi sesuai dan tidak sesuai } \\
\text { setiap kategorinya } \\
\text { - Teknik GIS dalam mengetahui sebaran vegetasi dengan } \\
\text { luasan yang sesuai setiap fungsi ekologisnya }\end{array}$ \\
\hline 5 & $\begin{array}{l}\text { Perumusan } \\
\text { Rekomendasi }\end{array}$ & $\begin{array}{l}\text { Perbaikan fungsi ekologis RTH dan Kualitas Vegetasi } \\
\text { RTH lanskap Permukiman cluster Bukit Golf Hijau } \\
\text { Sentul City. }\end{array}$ \\
\hline
\end{tabular}




\section{KONDISI UMUM CLUSTER BUKIT GOLF HIJAU SENTUL CITY}

\section{Sejarah}

PT. Sentul City Tbk merupakan suatu perseroan terbatas yang bergerak di bidang property dengan kegiatan utamanya adalah sebagai pengembang perkotaan (urban development) yang meliputi aktivitas pembangunan infrasturktur dengan segala fasilitasnya termasuk pengadaan ruang terbuka hijau. PT. Sentul City Tbk didirikan pada tanggal 16 April 1993 berdasarkan akta No. 311 dengan nama perseroan PT. Sentragriya Kharisma. Pada tahun yang sama yaitu tanggal 9 Agustus nama perseroan diubah menjadi PT. Royal Sentul Highlands. Tahun 1997, PT. Royal Sentul Highlands melakukan penawaran saham dengan sehingga pada tanggal 7 Desember 1997 berubah menjadi PT. Royal Sentul Highlands Tbk. Pada tanggal 11 Desember 1997, nama perseroan diubah menjadi PT. Sentul City Tbk.

PT. Sentul City memiliki kegiatan utama yaitu pengembangan perkotaan dengan berbagai fasilitas didalamnya yang meliputi pembangunan perumahan, perkantoran, pertokoan, fasilitas rekreasi dan olahraga, sekolah dan lain-lain. Selain itu, penyediaan lahan siap bangun bagi investor, pengembangan kawasan permukiman, pembangunan gedung-gedung komersial dan non komersial serta penyelenggaraan jasa yang terkait dengan pembangunan kota juga merupakan beberapa kegiatan dari usaha PT. Sentul City Tbk. Dalam hal ini PT. Sentul City Tbk hanya melakukan pengembangan tidak melakukan pengelolaan ataupun pemeliharaan. Selain itu PT ini juga mengembangkan beberapa perusahaan asosiasi dan dikembangkan oleh perseroan dalam rangka untuk memperoleh hasil kegiatan usaha maksimal dalam jangka panjang.

Bukit Golf Hijau (BGH) adalah salah satu cluster pertama yang dibuat di Sentul City sebelum pengelolanya dialihkan ke PT. Sentul City Tbk. Cluster ini sudah ada sejak dilakukannya pematangan dan lahan konstruksi pada tahun 1993 dan terjadi serah terima tahun 1995. Lanskap cluster BGH adalah lanskap buatan yang sudah berumur 15 tahun. 


\section{Letak, Luas, dan Aksesibilitas}

Lokasi kegiatan pembangunan perumahan Sentul City berada pada 8 wilayah Desa dan 2 Kecamatan, meliputi : Desa Cipambuan, Desa Babakan Madang, Desa Citaringgul, Desa Bojong Koneng, Desa Sumur Batu, Desa Cijayanti, Desa Kadumanggu, dan Desa Cadas Ngampar. Kecamatannya yaitu Kecamatan Babakan Madang dan Kecamatan Sukaraja. Batas wilayah dari Sentul City yaitu sebagai berikut:

Utara $\quad$ : Desa Cipambuan dan Desa Kadungmanggu.

Selatan : Desa Nanggrak dan Desa Cijayanti.

Barat : Desa Cijayanti, Desa Cikeas, dan Desa Cadas Ngampar.

Timur : Desa Hambalang dan Desa Karang Tengah.

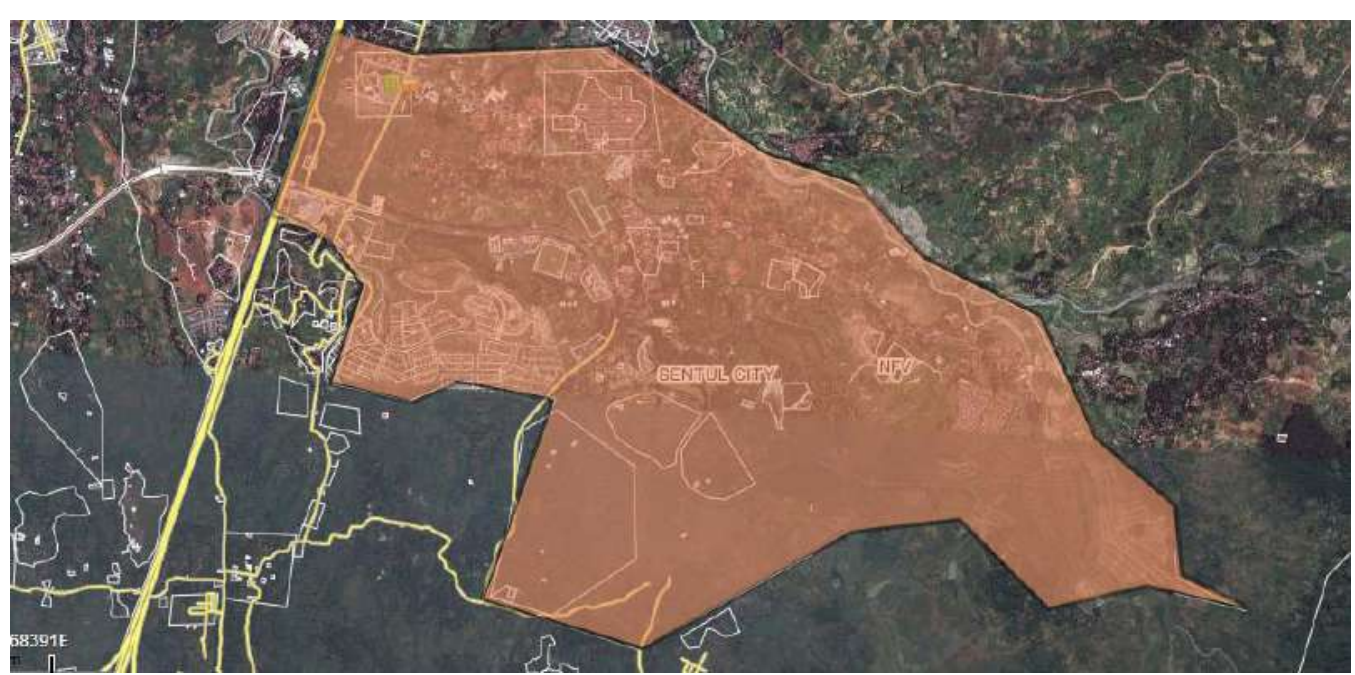

Gambar 5. Batas-Batas Wilayah Sentul City (www.maps.google.com, 2010)

Berdasarkan AMDAL (2009), kawasan permukiman Sentul City memiliki luas 2.334,53 ha, tetapi berdasarkan perencanaan sesuai master plan luas Sentul City mencapai 2.465 ha yang terletak pada batasan kawasan seluas 3.001,4 ha. Kawasan ini mencakup delapan desa dan dikelilingi oleh beberapa gunung. Kawasan ini dilalui oleh aliran Sungai Citeureup, Sungai Cikeas, Sungai Citaringgul, dan Sungai Cijayanti. Cluster BGH berada di Desa Cijayanti. Cluster ini memiliki Gross Area sekitar 884,545 $\mathrm{m}^{2}$ atau 88,5 ha. Area disini dibagi menjadi 2 macam, Efektif Area dan Non Efektif Area. Efektif Area terdiri dari 
luas kavling (541,131 $\left.\mathrm{m}^{2}\right)$ dan KDB (295,385 m², 33.39\%). Non Efektif Area terdiri dari luas hijau, fasilitas umum/sosial $\left(242,240 \mathrm{~m}^{2}\right)$, luas jalan dan saluran $\left(101,174 \mathrm{~m}^{2}\right)$, dan $\operatorname{KDB}\left(82,241 \mathrm{~m}^{2}, 9.3 \%\right)$.

Kawasan permukiman Sentul City mempunyai akses langsung yang terdekat yaitu tol lingkar luar Bogor dan tol Jagorawi (Jakarta-Bogor). Akses lain menuju kawasan selain melalui jalan tol yaitu melalui kompleks perumahan Bogor Baru menuju Desa Cimahpar kemudian ke Desa Cijayanti dengan kondisi jalan beraspal. Berikut Tabel perincian luas lahan di setiap desa (Tabel 5.).

Tabel 5. Perincian Luas lahan di Setiap Desa (Sumber: AMDAL 2009)

\begin{tabular}{|c|c|c|}
\hline No. & Nama Desa / Kecamatan & Luas $\left(\mathrm{m}^{2}\right)$ \\
\hline & Kecamatan Babakan Madang & \\
\hline 1. & Cipambuan & 683,22 \\
\hline 2. & Babakan Madang & $2.035,76$ \\
\hline 3. & Citaringgul & $2.923,64$ \\
\hline 4. & Bojong koneng & $10.049,68$ \\
\hline 5. & Sumur Batu & $3.655,29$ \\
\hline $6 . C$ & Cijayanti & $3.621,64$ \\
\hline 7. & Kadumanggu & 11,42 \\
\hline \multirow{3}{*}{8.} & Kecamatan Sukaraja & \\
\hline & Cadas Ngampar & 365,87 \\
\hline & TOTAL & $23.346,53$ \\
\hline
\end{tabular}

\section{Klimatologi}

Berdasarkan stasiun pengukur iklim Badan Meteorologi dan Geofisika (BMG) Darmaga Bogor, suhu rata-rata bulanan kawasan permukiman Sentul City dari Januari 2009 hingga Desember 2009 adalah 26,0 ${ }^{\circ} \mathrm{C}$. Suhu tertinggi yaitu $26,6^{\circ} \mathrm{C}$ pada bulan September 2009 dan suhu terendah yaitu $25,0^{\circ} \mathrm{C}$ berada pada bulan Januari 2009. Data rata-rata Kelembaban udara bulanan dari Januari hingga Desember 2009 adalah 81\%. Dengan kelembaban udara tertinggi yaitu 88\% pada bulan Januari hingga Februari 2009, sedangkan kelembaban udara terendah yaitu 75\% pada bulan Agustus hingga September 2009.

Data curah hujan per bulan dari Agustus 2007 hingga juli 2008 adalah 210,25 mm/bulan, tertinggi pada bulan Maret 2008 dengan curah hujan 404 mm/bulan dan terendah pada bulan Juli 2008 dengan curah hujan 25 mm/bulan. 
Data rata-rata Kecepatan angin per bulan dari Januari 2008 hingga Desember 2009 yaitu 2,55 Knots, tertinggi pada bulan Februari 2009 dengan kecepatan angin 3,5 Knots dan terendah pada bulan Juni 2008 dengan kecepatan 2,0 Knots.

Berdasarkan klasifikasi iklim menurut Mohr kawasan permukiman Sentul City terletak dalam daerah tipe iklim dengan bulan basah sepanjang tahun yaitu tipe iklim yang sepanjang tahun curah hujan rata-ratanya lebih dari 100 mm/bulan atau termasuk tipe iklim A dalam klasifikasi iklim menururt Schmidt dan Ferguson. Semua nilai data iklim dapat dilihat pada Tabel 6.

Tabel 6. Data Iklim Sentul City (Sumber: BMKG)

\begin{tabular}{|c|c|}
\hline Parameter & Nilai \\
\hline \multicolumn{2}{|l|}{ Suhu Udara $\left({ }^{\circ} \mathrm{C}\right)$} \\
\hline Minimum & 25,0 \\
\hline Maksimum & 26,6 \\
\hline \multicolumn{2}{|c|}{ Kelembaban Udara (\%) } \\
\hline Minimum & 75 \\
\hline Maksimum & 88 \\
\hline \multicolumn{2}{|c|}{ Curah Hujan (mm/tahun) } \\
\hline Minimum & 25 \\
\hline Maksimum & 404 \\
\hline \multicolumn{2}{|c|}{ Kecepatan Angin (Knots) } \\
\hline Minimum & 2,0 \\
\hline Maksimum & 3,5 \\
\hline
\end{tabular}

\section{Topografi}

Sentul City berada di atas ketinggian 200-750 m di atas permukaan laut. Kawasan secara umum berbukit-bukit. Kemiringan lereng berkisar antara 0-45\%. Tanah berbukit-bukit sebagai topografi alamiah Sentul City dipertahankan. Keadaan tersebut disiasati oleh perencana dengan lanskap jalan yang berkelokkelok dan rumah yang terletak di atas jalan (up slope) dan di bawah jalan (down slope). Sedangkan pada cluster BGH ketinggiannya mencapai $300 \mathrm{~m}$ di atas permukaan laut. 


\section{Geologi}

Berdasarkan penelitian studi AMDAL (2009), tanah di kawasan permukiman Sentul City dikelompokkan ke dalam lima klasifikasi tanah yaitu Aquic Dystropept, Oxic Dystropept, Typic Dystropept, Typic Hapludult, dan Typic Humitropept.

1. Aquic Dystropept memiliki sifat sering jenuh air dan sering tergenang.

2. Oxic Dystropept dengan karakter yang sama dengan Typic Dystropept, struktur tanah berpasir atau berdebu (kandungan liat 15\%).

3. Typic Dystropept mempunyai laju infiltrasi air dari rendah sampai tinggi, ketersediaan kalium rendah, Kapasitas Tukar Kation (KTK) rendah, dan Kejenuhan Basa (KB) sangat rendah.

4. Typic Hapludult dengan karakteristik tanah laju infiltrasi yang rendah dan kapasitas memegang air cukup baik, kandungan bahan organik sedang, dan kandungan $\mathrm{P}_{2} \mathrm{O}_{5}$ sangat rendah.

5. Typic Humitropept dengan sifat hampir sama dengan Typic Dystropept yaitu berasal dari great group trop dengan tingkat dekomposisi tanah sedang (hemis).

Kandungan bahan organik sangat mempengaruhi sifat fisik, kimia, dan biologi tanah. Bahan organik terutama berperan selain sumber energi, rantai makanan di dalam tanah, juga sebagai pengatur kelembaban dan aerasi, pemantapan struktur dan sebagai sumber hara potensial terutama N, P, K serta meningkatkan kapasitas tukar kation (KTK). Kandungan bahan organik tanah di kawasan Sentul City umumnya tergolong sedang berkisar antara 3,8-5,2\%, sebagian kecil yaitu pada tanah Type Humitropept kandungan bahan organiknya sedang hingga tinggi (5,0-8,6\%). Nilai KTK tanah di Sentul City termasuk sedang (17-24 ml/100 g tanah), kecuali pada tanah Oxic Dystropept dan Type Humitropept yang tergolong rendah (6-16 ml/100 g tanah). Penambahan bahan organik pada tanah dapat meningkatkan nilai KTK.

Secara umum kelima macam tanah tersebut memiliki KTK, kejenuhan basa (KB) serta kandungan P2O5 dalam tanah yang rendah, kecuali bahan organik tergolong sedang sampai rendah. Kondisi ini mengakibatkan tanah di Sentul City sangat miskin hara, sehingga kesuburan tanahnya rendah kecuali pada tanah Aquic 


\begin{abstract}
Dystropept dengan status kesuburan sedang. Akibatnya berpengaruh pada aspek pemupukan dan pengolahan tanah. Dalam lanskap, lahan seperti ini dilapis dengan tanah baru yaitu tanah merah yang diambil dari daerah lain sebagai media tanam dengan ketebalan 30-50 cm.
\end{abstract}

\title{
Hidrologi
}

Berdasarkan AMDAL (2009), air di kawasan berasal dari air sungai, air tanah, dan mata air dengan kuantitas yang sedikit. Sungai yang melewati kawasan permukiman Sentul City adalah Sungai Cikeas dan Sungai Citereup merupakan sungai yang permanen yang berair sepanjang tahun, sedangkan anak-anak sungainya yang hanya berair pada musim hujan saja. Air tanah hanya terdapat dalam bentuk air tanah dangkal dengan kedalaman muka air tanah antara 4-12 m. Potensi air tanah bebas di kawasan ini sangat terbatas dan sangat dipengaruhi oleh musim. Mata air merupakan sumber air yang mengalir langsung menjadi aliran permukaan pada sungai-sungai yang ada pada kawasan ini dengan debit air yang umumnya kecil yaitu kurang lebih sebesar 1/detik.

Dari hasil evaluasi AMDAL Sentul City 2009 bahwa lingkungan semakin berkurangnya ketersediaan air (hilangnya mata air), hal ini terjadi karena adanya penimbunan lereng dan lembah pada kegiatan lansekaping atau rekonturing. Sehingga metode yang dilakukan oleh pelaksana yaitu tidak menimbun rembesan air dan mata air, mengganti sarana air bersih penduduk yang hilang.

Beberapa danau buatan di Sentul City dijadikan sebagai sumber air bersih dan dikelola oleh pengelola Sentul City yang biasa disebut dengan sistem pengolahan air bersih secara mandiri atau Water Treatment Plant (WTP). Terdapat dua jenis WTP di Sentul City, tetapi sejak tahun 2006, pihak pengelola bekerjasama dengan PDAM Bogor, sehingga 50\% sumber air berasal dari PDAM Bogor. WTP Permanen dan WTP Temporari masih digunakan hanya sebagai back-up jika terjadi masalah pada saat supply dari PDAM. Semua sumber air bersih tersebut di distribusikan ke Balancing Tank (pusat jaringan pipa dan distribusikan jika ada filter dan digunakan sebagai tank sementara) di kawasan bawah tanah Helipet. Kapasitasnya $\pm 3500 \mathrm{~m}^{3}$. Berikut hidrologi dari kawasan Sentul City (Tabel 7.) 
Tabel 7. Data Hidrologi Sentul City (Sumber: AMDAL 2009)

\begin{tabular}{ccc}
\hline No. & Sumber Air & Bukit Sentul \\
\hline 1. & Sungai & Sungai Cikeas dan Sungai Citereup \\
\hline 2. & Air Tanah & $4-12 \mathrm{~m}$ di bawah permukaan tanah \\
\hline
\end{tabular}

\section{Vegetasi dan Satwa}

Pelaksanaan pemeliharaan vegetasi di Sentul City dilakukan oleh PT. Bukit Sentul Tbk Divisi Lanskaping. Pengawas kegiatan ini berada pada PT. Bukit Sentul Tbk Div. Pemeliharaan dan Bapedalda Tk. II Bogor dan pelaporan pada Bapedalda Tk II Bogor dan Bapedalda Tk. I Provinsi Jawa Barat. Sentul City juga melakukan penanaman tumbuhan eksotik dan langka khas Jawa Barat. Hal ini dilakukan karena menurunnya jumlah dan ragam tanaman lokal khas Jawa Barat. Sehingga metoda yang digunakan yaitu menanam tumbuhan khas jwa Barat. Selain itu banyak tumbuh tanaman liar yang dapat meningkatnkan frekuensi gangguan hama tanaman pertanian, sehingga metoda yang digunakan yaitu revegetasi dan perawatan lahan terbuka atau garapan. Dan mensyaratkan penggarapan untuk membebaskan lahan garapan dari semak belukar selama penggarapan. Dibangun dengan menerapkan presentase lahan hijau dibanding bangunan sebesar 65:35. Vegetasi asli yang tumbuh yaitu tanaman pangan atau tanaman budi daya seperti padi, pisang, talas, ketela pohon, dan kacang tanah. Adapula jenis tanaman hutan, kebun campuran, tegalan, dan semak belukar.

Berdasarkan AMDAL Sentul City tercatat terdapat 42 jenis spesies satwa. Jenis satwa tersebut terdiri dari 7 spesies amphibi, 7 spesies reptil, 22 spesies burung, dan 6 spesies mamalia. Namun saat ini hanya beberapa satwa yang ditemui, antara lain kupu-kupu dan lebah. Spesies burung yang ada disini yaitu burung gereja sampai burung madu, dan mereka umumnya bersarang di pohon Ki Hujan. Di Sentul City banyak hewan langka yang dilestarikan. Tapi habitat burung semakin berkurang di kawasan ini oleh karena itu metoda yang digunakan yaitu menyediakan makan bagi burung dan menanam tanaman yang menarik bagi burung. Oleh karena itu penting bagi pelaksana untuk melestarikan hewan yang ada disana untuk dijaga agar tidak punah. Beberapa jenis hewan tersebut mayoritas berupa burung-burung langka. Melarang perburuan satwa kecuali hama di lokasi. 


\section{Sosial}

Secara umum permukiman penduduk yang berada di Kecamatan Sukaraja, babakan Madang, dan Citereup terbagi atas dua kategori permukiman yaitu permukiman yang terencana tumbuh dan permukiman yang tidak terencana. Permukiman yang terencana tumbuh dalam dua sampai tiga dekade terakhir dibangun dalam skala menengah dan besar untuk masyarakat berpendapatan menengah dan menengah ke atas. Permukiman yang tidak terencana berupa pola perkampungan terdapat di dalam kawasan Sentul City dan sekitarnya yang berbentuk memanjang, terapit, dan mengikuti jalur jalan, serta lembah atau bukit dibelakangnya dengan keberadaan toko dan usaha perdagangan penduduk setempat.

Cluster BGH termasuk dalam kategori permukiman yang terencana. Mayoritas penghuni cluster ini bermata pencaharian sebagai pegawai kantoran dan pengusaha. Jumlah kavling yang ada di cluster ini sekitar 1038 unit. Umumnya penghuni di cluster BGH menempati rumahnya ketika hari libur, yaitu sabtuminggu. Karena menurut pengelola, penghuni mayoritas ingin tinggal di Sentul City untuk menghilangkan kepenatan dari rutinitas kerja di hari senin-jumat, sehingga membutuhkan suasana baru yang dapat diberikan hanya di Sentul City. Oleh karena itu, pada hari biasa rumah hanya akan ditempati oleh pegawai rumah tangga masing-masing.

\section{Tata Guna Lahan}

Permukiman Sentul City memiliki kawasan wilayah terbangun (KWIT) sebesar 30\% dari 2465 Ha luas total kawasan. Secara lengkap peruntukan lahan tersebut terdiri dari 8 macam yaitu permukiman, area perdagangan dan perkantoran, fasilitas komersial, jalan utama/primer, interchange, jalan lingkungan, ruang terbuka hijau dan fasilitas umum sosial (Tabel 8.) 
Tabel 8. Data Tata Guna Lahan Sentul City (Sumber: AMDAL 2009)

\begin{tabular}{clcc}
\hline No. & \multicolumn{1}{c}{ Tata Guna Lahan } & Luas Efektif & $\begin{array}{c}\text { Proporsi terhadap } \\
\text { Luas Total (\%) }\end{array}$ \\
\hline 1. & Permukiman & 1026.74 & 41.7 \\
2. & Perdagangan dan Perkantoran & 209.70 & 8.5 \\
3. & Fasilitas Komersial & 242.50 & 9.8 \\
4. & Jalan Utama / Primer & 88.70 & 3.6 \\
5. & Interchange & 15.00 & 0.6 \\
6. & Jalan Lingkungan & 27.87 & 11.4 \\
7. & Ruang Terbuka Hijau & 552.18 & 22.4 \\
8. & Fasilitas Umum Sosial & 50.31 & 2.0 \\
\hline & TOTAL & 2465.00 & 100.0 \\
\hline
\end{tabular}

Pembangunan berbagai macam sarana dan prasarana serta fasilitas pda kawasan permukiman Sentul City bertujuan untuk memenuhi berbagai macam kebutuhan penghuni serta bersifat memberikan pelayanan pusat kawasan dan pelayanan pusat lingkungan. Peruntukan lahan yang efektif yaitu seluas 2.465 ha. Luas lahan ini efektif dimanfaatkan untuk perumahan dan fasilitasnya, luas lahan yang tidak efektif ini keadaan kemiringan lerengnya lebih dari 40\%. Semua terlihat pada rencana peruntukan lahan efektif dan rencana peruntukan lahan terbangun dengan proporsi terhadap luas area 2.465 ha. Wilayah terbangun dengan proporsi terhadap luas area 2.465 ha yaitu 29,95\%. Berdasarkan UndangUndang Republik Indonesia No. 26 Tahun 2007 tentang Penataan Ruang pada pasal 29 ayat 2 adalah proporsi ruang terbuka hijau pada wilayah kota paling sedikit 30\% dari wilayah kota, maka permukiman Sentul City sudah memenuhi persyaratan tentang ruang terbuka hijau. Tata guna lahan di dalam cluster BGH sendiri hanya terbagi menjadi wilayah permukiman, fasilitas, RTH, dan kavling kosong. 


\section{ANALISIS DATA DAN PEMBAHASAN}

\section{Identifikasi Karakteristik RTH Lanskap Permukiman}

RTH yang akan dievaluasi merupakan salah satu RTH yang berada dalam kawasan permukiman, dimana permukiman tersebut berada di salah satu cluster yang terletak di Sentul City yaitu cluster Bukit Golf Hijau (BGH). Cluster BGH merupakan cluster pertama yang dibuat oleh Sentul sebelum dimiliki oleh PT. Sentul City Tbk. Cluster BGH berbeda dari yang lainnya karena memiliki RTH terluas dibandingkan dengan cluster-cluster lain di Sentul City. Karakteristik RTH hanya mencangkup keragaman pohon yang ada di cluster tersebut, tidak termasuk jenis semak dan perdu yang ada.

RTH di cluster BGH umunya ditanami oleh vegetasi yang lebih fungsional dibandingkan estetika, berbeda dengan RTH yang ada di kawasan lain, seperti RTH sepanjang jalan Thamrin-Siliwangi yang lebih dominan oleh fungsi estetikanya.

Jenis tanah di cluster ini merupakan jenis dimana tanah tersebut memiliki nilai KTK, kejenuhan basa (KB) serta kandungan $\mathrm{P}_{2} \mathrm{O}_{5}$ dalam tanah yang rendah (tidak bisa padat dan lembab). Kondisi ini mengakibatkan tanah di Sentul City sangat miskin hara, sehingga kesuburan tanahnya rendah. Hal ini dikarenakan pada kawasan ini sangat sulit untuk mendapatkan penyinaran matahari, karena jarak penanaman antar vegetasi dekat, sehingga sulit bagi matahari untuk menembus tajuk-tajuk dari pohon. Akibatnya berpengaruh pada aspek pemupukan dan pengolahan tanah. Dalam lanskap, lahan seperti ini dilapis dengan tanah baru yaitu tanah merah yang diambil dari daerah lain sebagai media tanam dengan ketebalan 30-50 cm. Karena kondisi tanah seperti itu, maka tidak semua jenis vegetasi dapat ditanam di RTH cluster ini.

Di Sentul City jenis topografinya berupa bukit-bukit, ini pula sama halnya yang terjadi dengan cluster BGH. Di cluster ini, walaupun dijadikan sebagai permukiman, tetapi kondisi topografi tidak dirubah tetap berbukit-bukit. Ketinggiannya mencapai $300 \mathrm{~m}$ di atas permukaan laut. Sehingga rumah-rumah tampak tidak sejajar satu dengan lainnya. Begitu pula dengan RTH disana. Penanaman vegetasi dilakukan mengikuti medan cluster tersebut. 
Di cluster BGH terbagi menjadi 5 area yaitu BGH Raya, Bukit, Puncak, Gunung, dan Lembah. Setiap areanya memiliki RTH yang ditanam berbagai macam vegetasi. Pemilihan lokasi setiap areanya mengikuti topografi di kawasan tersebut. Semakin ke atas area dinamakan area gunung, dan semakin ke bawah area dinamakan area lembah. Berikut adalah gambar kondisi eksisting RTH di masing-masing area (Gambar 6, 7, 8, 9, dan 10) dan pembagian kawasan di cluster Bukit Golf Hijau (Gambar 15.).

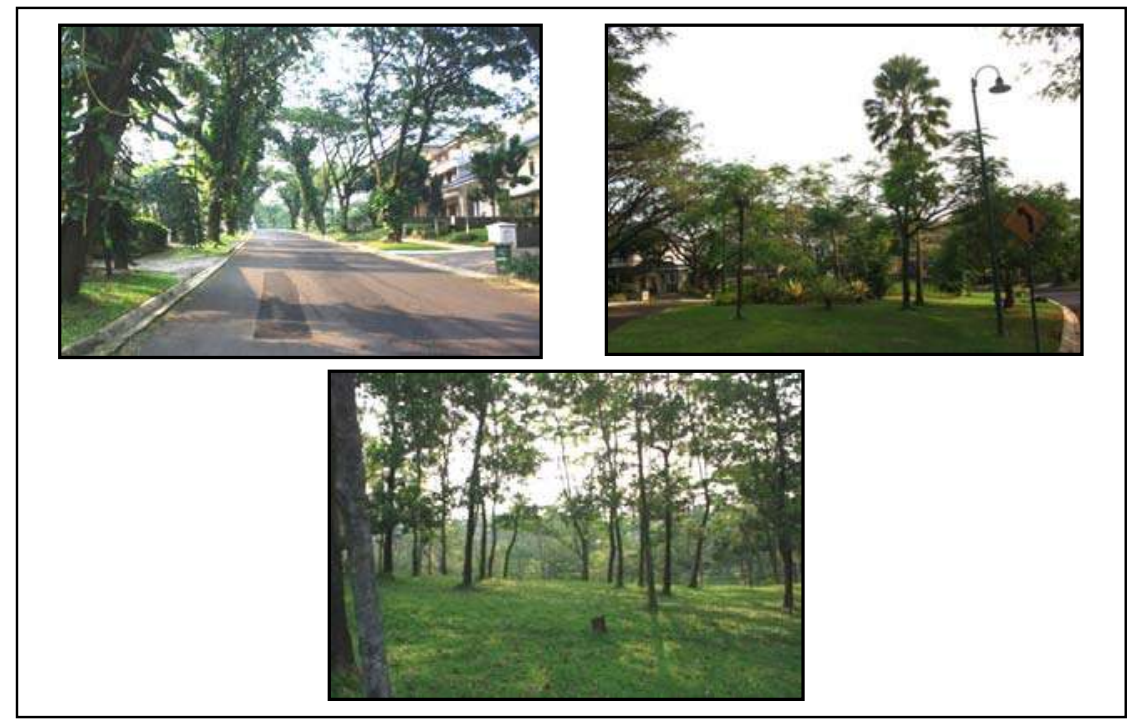

Gambar 6. Kondisi RTH Area Lembah (Sumber: Lapang, 2010)

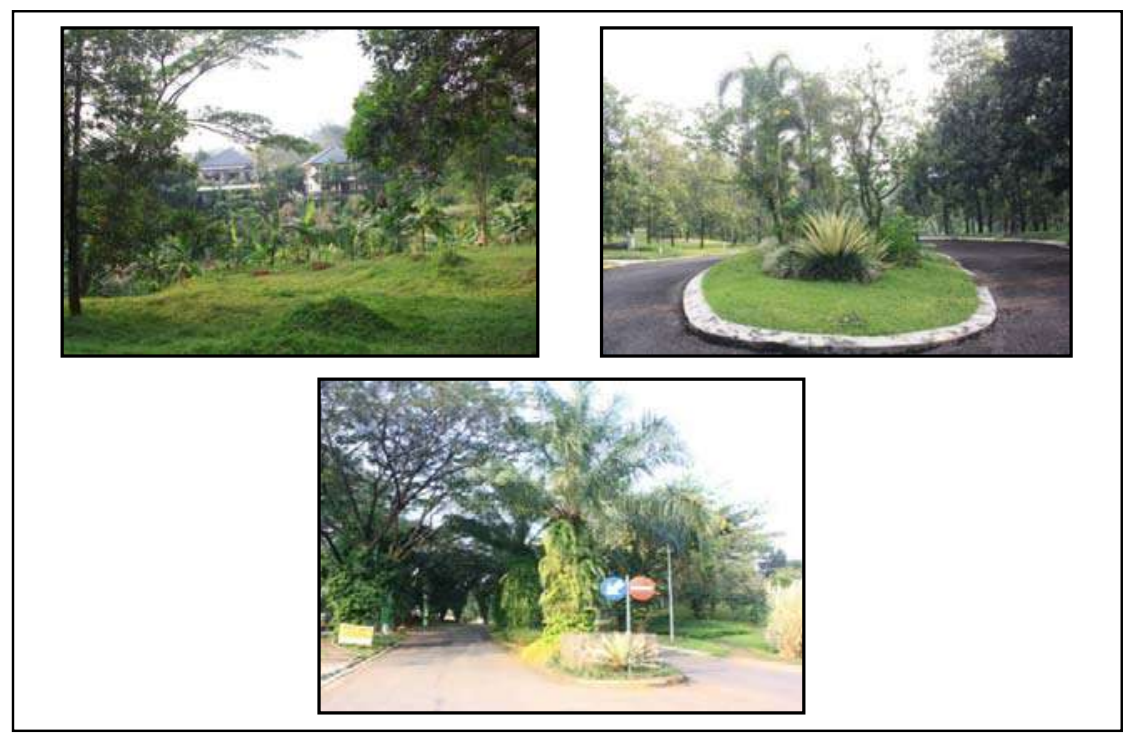

Gambar 7. Kondisi RTH Area BGH Raya (Sumber: Lapang, 2010) 

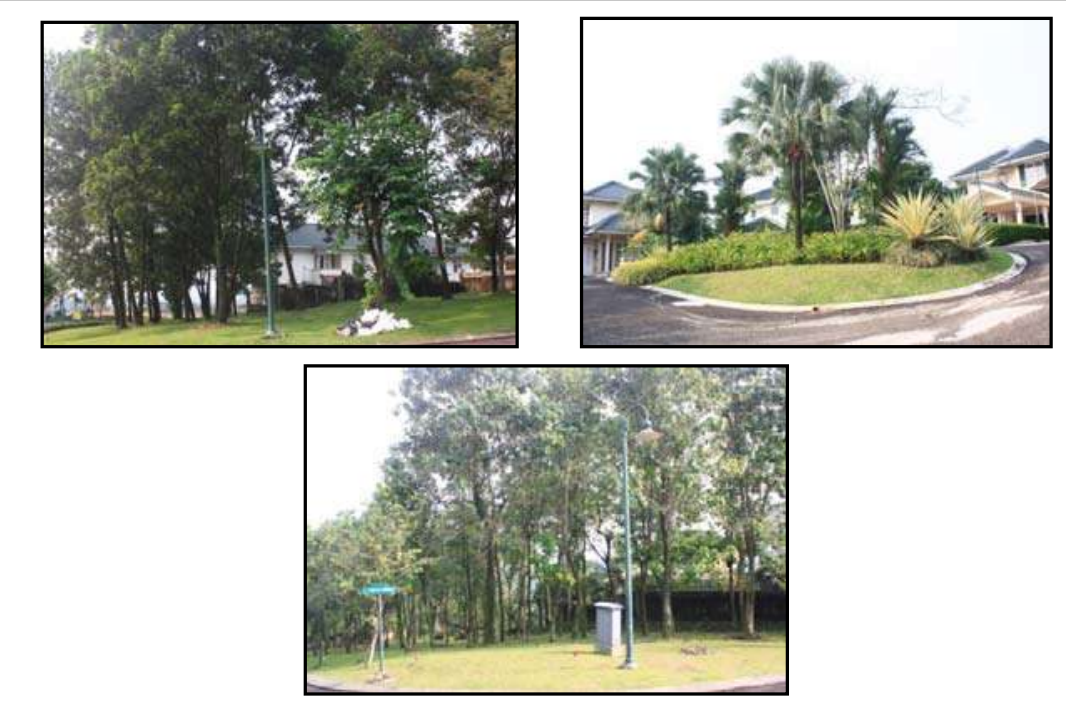

Gambar8. Kondisi RTH Area Puncak (Sumber: Lapang, 2010)
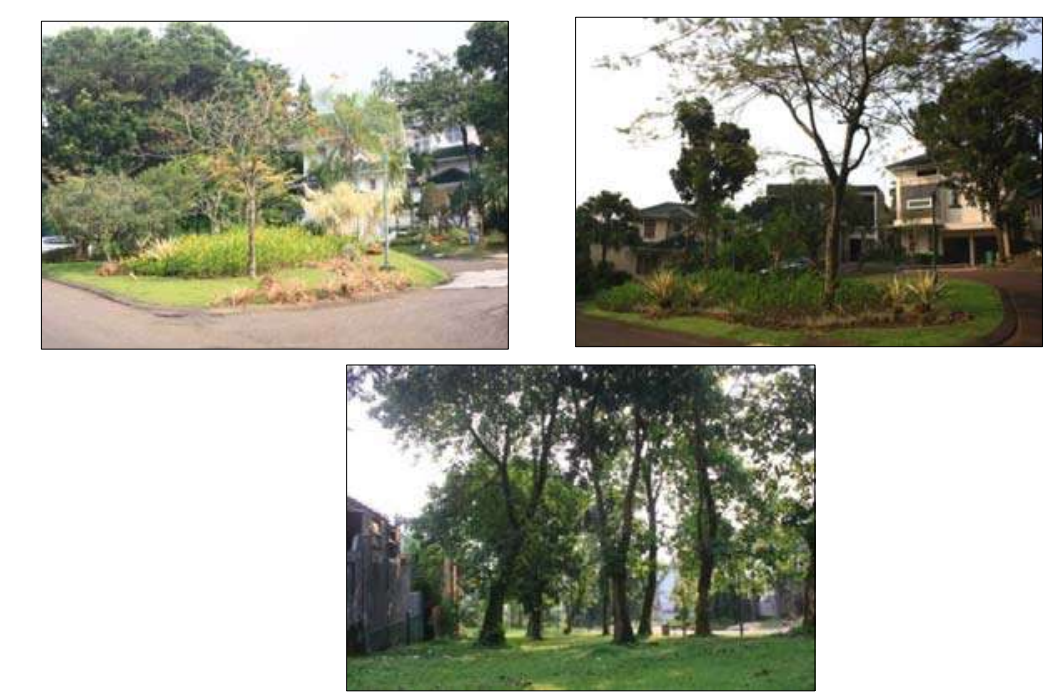

Gambar 9. Kondisi RTH Area Bukit (Sumber: Lapang, 2010)
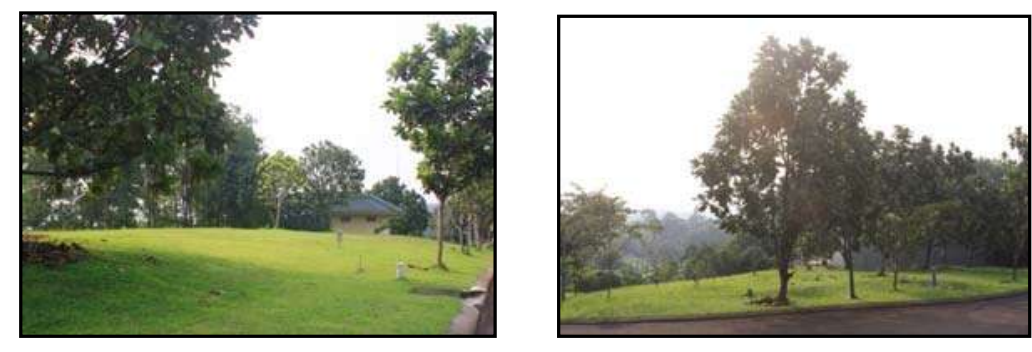


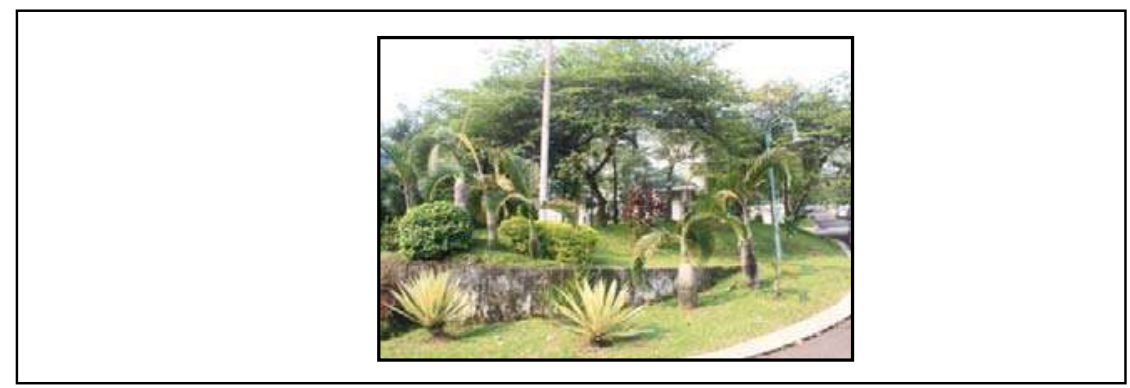

Gambar 10. Kondisi RTH Area Gunung (Sumber: Lapang, 2010)

Di setiap area cluster BGH ini terdapat RTH yang dikelompokkan menjadi 4, yaitu RTH di kavling kosong, RTH di area yang khusus untuk kawasan RTH, RTH Pocket Park (taman lingkungan), dan RTH di sepanjang jalan lingkungan.

- $\quad$ RTH berupa kavling kosong ini awalnya hanya vegetasi-vegetasi yang secara liar tumbuh di area tersebut, tetapi semakin dibiarkan maka menjadi RTH yang tidak sengaja, kemudian dikembangkan sembari menjual kavling tersebut. Keberadaan RTH ini berperan penting dalam meningkatkan fungsi ekologis permukiman (Gambar 11.).

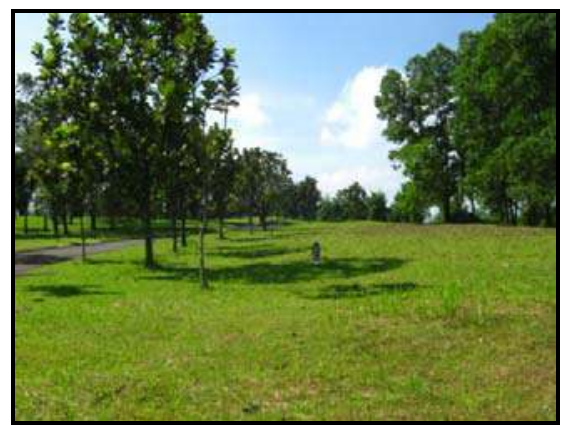

Gambar 11. RTH Kavling Kosong (Sumber: Lapang, 2010)

- $\quad$ RTH di area yang khusus untuk kawasan RTH memang diperuntukkan untuk ditanami oleh berbagai macam vegetasi guna untuk meningkatkan kualitas lingkungan permukiman tersebut. RTH ini umumnya ditanam pada daerahdaerah curam yang tidak layak dijadikan sebagai kavling, sehingga dialih fungsikan menjadi RTH (Gambar 12.). 


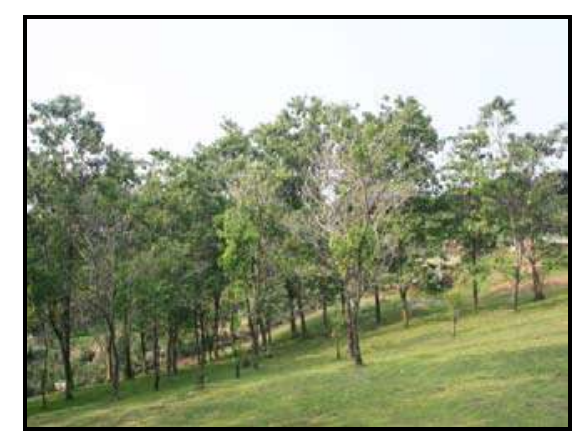

Gambar 12. RTH Khusus Kawasan RTH (Sumber: Lapang, 2010)

- $\quad$ RTH Pocket Park (Taman Lingkungan) di BGH umumnya ditanami berbagai jenis vegetasi tidak hanya jenis pohon, tetapi juga terdapat perdu dan semak. Umumnya RTH ini lebih menonjolkan aspek estetika dibanding fungsional, sehingga disini lebih banyak keragaman jenis vegetasi dibanding RTH lainnya (Gambar 13.).

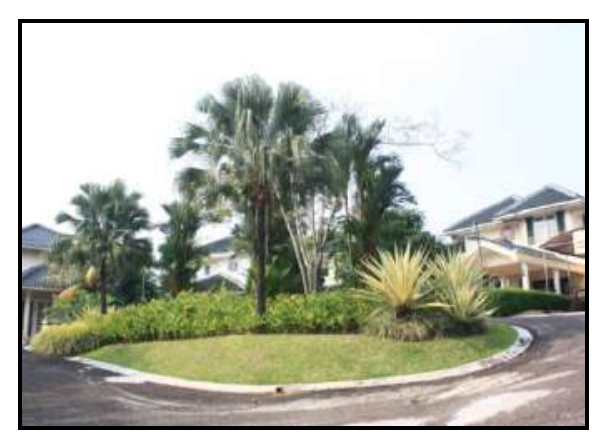

Gambar 13. RTH Pocket Park (Sumber: Lapang, 2010)

- RTH sepanjang jalan lingkungan berada di setiap jalan cluster BGH, dan hanya ditanami oleh beberapa jenis vegetasi yang fungsinya sebagai pohon peneduh untuk kendaraan dan pengguna pedestrian jalan. Penanaman jenis vegetasi kurang cocok dengan kawasan, karena akar-akar yang keluar dari batang pohon menjalar keluar jalan (Gambar 14.) 


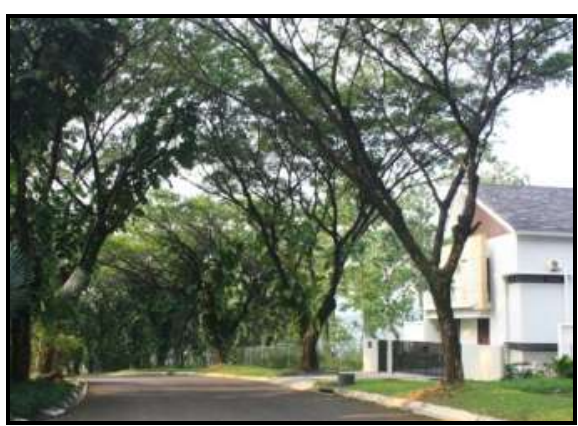

Gambar 14. RTH di Sepanjang Jalan Lingkungan (Sumber: Lapang, 2010)

Berdasarkan hasil wawancara oleh pihak pengelola lanskap Sentul City, Tidak ada vegetasi eksisting di kawasan ini, semua merupakan vegetasi yang sengaja ditanam dalam pembangunan cluster tersebut. Sehingga banyak vegetasi yang kurang sesuai kemampuan pervegetasinya dengan kondisi yang ada disana dan akhirnya banyak vegetasi yang mati. Menurut Booth (1983), Satu tujuan yang diinginkan dari desain menggunakan material vegetasi adalah memilih vegetasivegetasi yang menuntut sedikit pemeliharaan. Salah satu pendekatan yang akan lebih diterima yaitu menggunakan vegetasi-vegetasi asli setempat pada pengelompokkan-pengelompokkan ekologi dibanding yang terkenal, kultivar varietas nurseri. Karena vegetasi eksisting dapat tumbuh dengan baik di kondisi yang ada disana, sehingga pervegetasinya menjadi baik. 


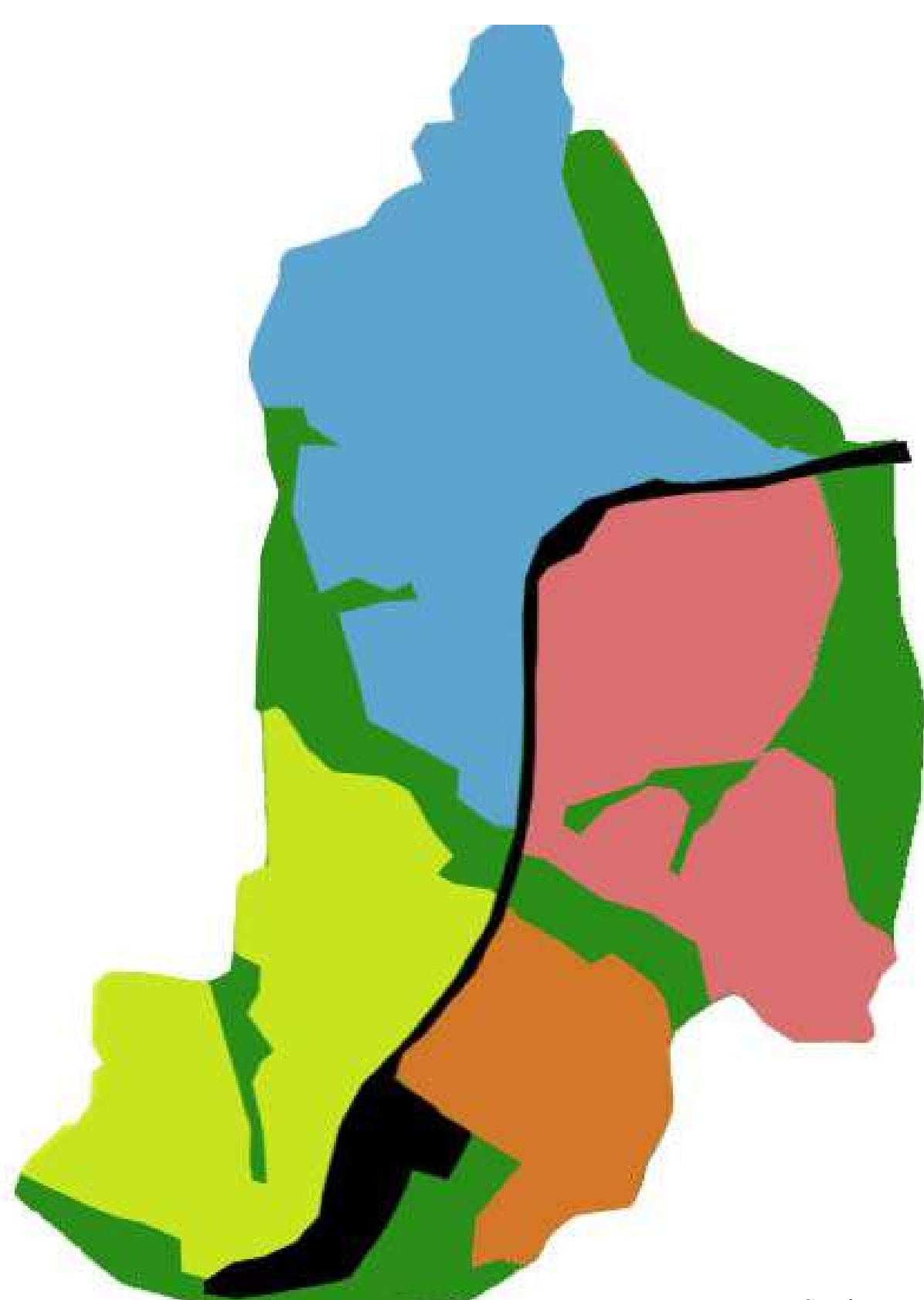

Sumber: Pengamatan lapang. 2010

\section{LEGENDA}

Area BGH Raya

Area Puncak

Area Bukit

Area Lembah

Area Gunung

RTH khusus untuk Kawasan RTH
DEPARTEMEN ARSITEKTUR LANSKAP FAKULTAS PERTANIAN

INSTITUT PERTANIAN BOGOR 2011

JUDUL PENELITIAN

EVALUASI FUNGSI EKOLOGIS POHON PADA RTH LANSKAP PERMUKIMAN SENTUL CITY, BOGOR (Studi Kasus: Cluster Bukit Golf Hijau)

JUDUL GAMBAR

PETA KAWASAN AREA DI CLUSTER BGH

DOSEN PEMBIMBING

Dr. Ir. ALINDA F. M. ZAIN, M.Si

CHANDRA NURNOVITA

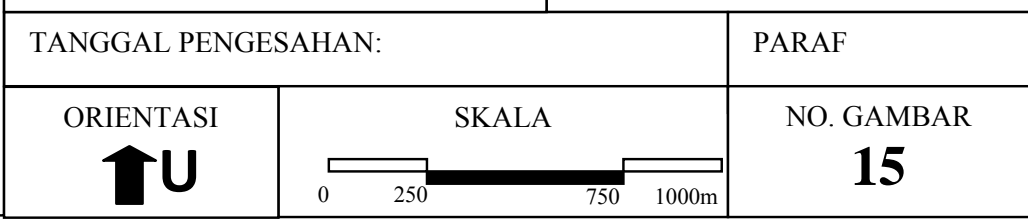




\section{Identifikasi Jenis Vegetasi}

Cluster Bukit Golf Hijau (BGH) ini merupakan cluster dengan RTH terluas dibandingkan dengan RTH-RTH di cluster lainnya. Dengan demikian, jenis vegetasi yang ada di RTH ini memiliki jumlah yang relatif banyak. Berdasarkan data AMDAL (2009) terdapat 1.377 pohon yang tumbuh di cluster BGH dengan terdapat 29 jenis pohon yang ada disana. Jenis vegetasi yang dominan ada di RTH tersebut adalah Biola Cantik (Ficus lyrata) sebanyak 345 pohon dan jenis vegetasi yang sedikit tumbuh adalah Sikat Botol (Callistemon citrianus) dan Mengkudu (Morinda citrifolia) hanya 1 pohon. Sedangkan dari hasil pemetaan melalui GPS (Global Positioning System), terdapat 1.163 pohon disana dan terdapat 38 jenis pohon yang ada. Karena kendala kawasan yang cukup curam dan banyak vegetasi yang tidak ikut dipetakan, maka pemetaan diutamakan pada keragaman vegetasi dibanding jumlah vegetasi, karena cluster ini sudah pasti memiliki vegetasi terbanyak dibanding cluster lain, tapi keragamannya belum tentu. Jenis vegetasi yang dominan di RTH cluster ini adalah Akasia (Acacia auriculiform) yang jumlahnya mencapai 164 pohon dan jenis vegetasi yang tumbuh sedikit adalah Kemuning (Murraya paniculata), Cemara Norflok (Araucaria heterophylla), Kecrutan (Spathodea campanulata), Kelengkeng (Dimocarpus longan), Angsana (Pterocarpus indicus), Bintaro (Cerbera odollan), dan Akasia Daun Lebar (Acacia auriculiform) yang hanya terdapat 1 pohon. Berdasarkan jumlah jenis keragaman dari kedua data sebelumnya, dapat disimpulkan bahwa dalam RTH cluster BGH terdapat peningkatan keragaman jenis pohon (Tabel 9.).

Tabel 9. Identifikasi Vegetasi Data Sekunder dan Data Primer.

\begin{tabular}{clccc}
\hline No. & Sumber dan Jenis Data & $\begin{array}{c}\text { Total Jenis } \\
\text { Vegetasi }\end{array}$ & $\begin{array}{c}\text { Total Banyaknya } \\
\text { Pohon }\end{array}$ & $\begin{array}{c}\text { Jenis Vegetasi } \\
\text { Dominan }\end{array}$ \\
\hline 1. & $\begin{array}{l}\text { Sekunder : AMDAL } \\
2009\end{array}$ & 29 Jenis & 1.377 & $\begin{array}{c}\text { Biola Cantik } \\
\text { (Ficus lyrata) }\end{array}$ \\
\hline 2. & $\begin{array}{l}\text { Primer : Pemetaan di } \\
\text { Lapang Dengan GPS }\end{array}$ & 38 Jenis & 1.029 & $\begin{array}{c}\text { Akasia (Acacia } \\
\text { auriculiform) }\end{array}$ \\
\hline
\end{tabular}

Karena tidak adanya vegetasi eksisting, maka pengelola Sentul City melakukan penanaman baru di RTH cluster BGH. Jenis vegetasi pertama yang ditanam (pohon perintis) yang berada di RTH cluster ini adalah Sengon 
(Paraserianthes falcataria), Gmelina (Gmelina sp.), dan akasia (Acacia auriculiform).

RTH yang telah teridentifikasi tidak termasuk pohon-pohon di setiap pekarangan rumah penghuni cluster BGH. Pembagiannya antara pohon yang ditanam oleh pengelola dan pohon yang ditanam oleh penghuni yaitu dipisahkan oleh pedestrian antara rumah dan jalan raya. Selain itu dipisahkan pula oleh kotak pos yang ada di depan setiap rumah. Semua pohon yang berada di antara kotak pos dan rumah itu termasuk pohon yang ditanam oleh penghuni rumah. Sedangkan pohon yang berada di antara kotak pos dan jalan raya termasuk pohon yang ditanam oleh pengelola.

Keragaman vegetasi di cluster ini meliputi semua area yang ada, karena dari pihak pengelola telah memberikan ciri khusus jenis vegetasi pada masingmasing area dan RTH-RTH yang ada didalamnya (Tabel 10.).

Tabel 10. Jenis Vegetasi Khas di Setiap Area Cluster BGH.

\begin{tabular}{clc}
\hline No. & \multicolumn{1}{c}{ Area } & Jenis Vegetasi Khas \\
\hline 1. & $\begin{array}{l}\text { Bukit Golf Hijau } \\
\text { (BGH) Raya }\end{array}$ & $\begin{array}{c}\text { Ki Hujan (Samanea saman) yang batangnya } \\
\text { dililiti oleh vegetasi Sirih Belanda }\end{array}$ \\
\hline 2. & Bukit & Mahoni (Swietenia mahagoni) \\
\hline 3. & Gunung & Biola Cantik (Ficus lyrata) \\
\hline 4. & Lembah & Biola Cantik (Ficus lyrata) \\
\hline 5. & Puncak & Bunga Kupu-kupu (Bauhinia blakeana) \\
\hline
\end{tabular}

Pada area BGH Raya semua pohon Ki Hujan yang terletak di samping kiri dan kanan jalan batangnya dililiti oleh Sirih Belanda. Hal ini dilakukan sematamata sebagai fungsi estetika saja. Padahal pada kenyataannya akar-akar dari Sirih Belanda ini mulai merusak utilitas-utilitas di bawah tanah, seperti air bersih, kabel telepon, dan kabel listrik. Solusinya yaitu selektif dengan pangkas akar dan daun. Selain itu saat penanaman awal pada lubang tanam hingga kedalaman $1 \mathrm{~m}$ dibuat perkerasan yang berbentuk silinder terbuka, agar waktu akar tumbuh tidak ke samping melainkan ke bawah sampai batas kedalaman perkerasan lalu baru ke samping. Hal ini untuk mencegah rusaknya utilitas yang berada di sekitar pohon. Tetapi ada pula keunggulan dari Ki Hujan yaitu jenis pohon ini tidak pernah dimakan rayap sehingga umumnya pohon jenis ini kuat dan tua. Ruang terbuka 
hijau yang ada di Sentul City umumnya buatan dan digunakan sebagai catchment area untuk meresap air.

Semua pemilihan pohon yang ada di RTH cluster BGH ini dipilih hanya untuk membuat imej pegunungan di kawasan Sentul City ini. Tapi disisi lain pemilihan pohonnya didasarkan demi kenyamanan penghuninya, salah satunya kenyamanan dari sinar matahari. Sehingga di Cluster ini umumnya penghuni merasa nyaman untuk tinggal karena merasa teduh dan tidak terlalu terkena sinar matahari yang menyengat.

Pemilihan jenis vegetasi di semua lanskap permukiman cluster $\mathrm{BGH}$ masih kurang mempertimbangkan manfaat vegetasi, khususnya pohon. Berikut daftar jenis vegetasi yang ada di BGH berdasarkan hasil pemetaan. Berdasarkan hasil inventarisasi di lapang, terdapat 38 jenis pohon yang ada di RTH cluster BGH. Dari hasil tersebut kemudian akan dianalisis setiap jenisnya bagaimana karakteristik pohon yang memiliki fungsi ekologis. Jenis-jenis vegetasi tersebut tersebar seperti pada Gambar 16. dan Gambar 17. Berikut merupakan daftar jenis vegetasi berdasarkan hasil data primer.

- Akasia (Acacia auriculiform)

Pohon ini tingginya dapat berkisar 30-40 m. Tajuknya lebar agak rapat tidak teratur dan bermassa daun rapat. Akasia banyak ditanam di pinggir jalan sebagai pohon peneduh. Pohon ini memiliki daun yang rimbun, cukup tebal, cukup halus, dan tangkai daun pendek. Daun Akasia tidak mudah gugur. Ukuran panjang daun 150-400 mm dan lebar 100-180 mm. Memiliki banyak jumlah daun. Diameter batang berukuran 80-100 cm. Cabang dan batang besar, batang lurus, keras dan bertekstur kasar. Dahan yang cukup kuat dan lentur.

- Akasia Daun Lebar (Acacia mangium)

Pohon ini berukuran sedang hingga besar, tinggi dapat mencapai $35 \mathrm{~m}$. Tajuknya menyerupai kerucut sampai lonjong, dengan massa daun kurang rapat. Daunnya yang rindang, besar, dan cukup halus memiliki panjang mencapai $25 \mathrm{~cm}$, lebar 3-10 $\mathrm{cm}$ dan tangkai daun cukup panjang, berwarna hijau gelap. Berdaun cukup tebal dan tidak mudah gugur. Vegetasi ini memiliki banyak jumlah daun. Cabang dan batang cukup 
besar, batangnya bulat lurus, bercabang banyak (simpodial), berkulit tebal agak kasar, dan kadang beralur kecil dengan warna cokelat muda. Diameter batang bisa mencapai lebih dari $75 \mathrm{~cm}$. Kulit kasar dan beralur, berwarna abu-abu atau coklat. Dahannya kuat tapi cukup lentur.

- Angsana (Pterocarpus indicus)

Angsana termasuk pohon tinggi dengan ketinggian mencapai 40 m. Tajuknya lebat serupa kubah, ranting-rantingnya merunduk dengan tajuknya yang rindang dan bermassa daun rapat. Daunnya majemuk, berselingan, tangkai daun pendek, berbentuk bulat telur dan pada musim kemarau sering rontok dan berdaun cukup tebal. Memiliki banyak jumlah daun. Diameter batang sekitar 100-150 cm. Bentuk batang lurus, beralur dangkal dengan buku-buku besar maupun kecil. Batang sering beralur atau berbonggol. perakarannya baik, tekstur cukup kasar. Cabang dan batang besar. Dahan yang kuat tapi cukup lentur. Daun cukup halus.

- Beringin (Ficus benjamina)

Beringin termasuk jenis pohon besar, kokoh, dan kuat dengan ketinggian mencapai $30 \mathrm{~m}$. Daunnya tunggal dan bertangkai, cukup halus, bermassa daun rapat dan tidak mudah gugur. Karena bentuk tajuk yang sangat menarik (kubah) dan warna daun yang hijau serta rimbun, Beringin banyak disenangi dan dimanfaatkan sebagai pohon peneduh. Diameter kanopi 2 m lebih. Cabang dan batang besar, tekstur batang kasar. Dahan yang kuat tapi cukup lentur.

- Beringin Karet (Ficus elastica)

Pohon ini tingginya berkisar 20-40 m. Tajuk vegetasi ini berbentuk horizontal (menyebar). Daun berwarna sangat kontras, berbentuk oval, tebal, sulit gugur dan mengilap, juga bermassa daun rapat. Cabang dan batang besar, cabang-cabang serta ranting-rantingnya berdiri kekar, menjulang ke langit. Bila vegetasi sudah besar cabang/rantingnya akan bergelantungan ke bawah. Vegetasi ini mempunyai banyak akar udara yang menuju ke luar tanah, yang nantinya akan menjadi batang. Batang tegak dan bertekstur halus. Tangkai daun pendek dan banyak jumlah daun. Dahan kuat tapi cukup lentur. Daun halus. 


\section{- Bintaro (Cerbera odollan)}

Pohon ini termasuk salah satu vegetasi rawa dan dapat mencapai ketinggian sampai $15 \mathrm{~m}$. Tajuknya melebar setengah lingkaran. Bentuk tajuknya yang menyebar sangat menunjang untuk dujadikan pohon naungan. Daun Bintaro bentuknya memanjang, tebal, simetris, tekstur halus, sulit gugur dan menumpul pada bagian ujung dengan ukuran bervariasi, tetapi rata-rata memiliki panjang $25 \mathrm{~cm}$ dan tangkai daun pendek. Daun banyak jumlahnya, tersusun secara spiral, terkadang berkumpul pada ujung roset, termasuk dalam kategori bermassa daun cukup rapat. Pohon bintaro merupakan vegetasi berkayu keras yang biasa dimanfaatkan sebagai pohon pelindung. dan diameter kanopi daunnya selebar $6 \mathrm{~m}$, sangat baik sebagai penghijauan terutama ditanah yang miring. cabang dan batang cukup besar. tekstur batang cukup halus. Dahannya kuat tapi cukup lentur.

- Biola Cantik (Ficus lyrata)

Biola cantik merupakan jenis pohon besar dengan ketinggian mencapai $25 \mathrm{~m}$. Tajuknya berbentuk globular (membulat) dan bermassa daun rapat. Jenis vegetasi ini memiliki daun-daun yang besar, tebal tersusun rapi, berwarna hijau tua Daun-daun vegetasi ini tidak mudah gugur. Helaian daun berbentuk bulat telur, kaku dengan panjang $25-35 \mathrm{~cm}$, lebar 15-20 cm. Tangkai daun panjang. jumlah daun cukup banyak. Pohon ini dapat tumbuh di tempat terbuka atau sedikit terkena sinar matahari. Cabang dan batang kurang besar. Dahan cukup kuat dan cukup lentur. Daun kurang kasar. batang bertekstur kasar.

\section{- Bunga Kupu-Kupu (Bauhinia blakeana)}

Tingginya berkisar 6-12 m. Tajuknya menyebar (spread) dengan lebar 6-7,5 $\mathrm{m}$ dan bermassa daun kurang rapat. Daun berwarna hijau menyerupai hati. Lebar daun 15-20 cm dengan 8-10 tulang daun, kurang tebal. Tangkai daun pendek. Daun sulit gugur. Jumlah daun cukup banyak. Cabang dan batang kurang besar. Kayunya tidak mudah patah meski ada angin kencang. tumbuhnya perakaran tidak terlalu cepat menyangkut 
timbulnya akar pada jalan. Dahan yang kuat tapi cukup lentur. Daun halus. Batang cukup kasar.

- Cemara Norflok (Araucaria heterophylla)

Jenis cemara ini memiliki tinggi mencapai $60 \mathrm{~m}$. Tajuknya berbentuk piramidal dan bermassa daun cukup rapat. Daun berbentuk seperti jarum sepanjang 1-1,5 cm dan tebal. Daunnya selalu hijau dan tidak pernah gugur (evergreen). Tidak ada tangkai daun tetapi memiliki banyak jumlah daun. Cabang dan batang besar. Batang vegetasi kasar, mencapai ketinggian $5 \mathrm{~m}$ lebih dengan cabang-cabang melintang atau tumbuh horizontal mengelilingi pohon. Dahan yang kuat tapi cukup lentur.

- Dadap Merah (Erythrina cristagali)

Dadap Merah merupakan pohon yang berukuran sedang dengan tinggi 6-7 $\mathrm{m}$ dan gemang 50-60 $\mathrm{cm}$. Tajuknya serupa payung atau membulat renggang, horizontal (menyebar), lebar, dan bermassa daun kurang rapat. Menggugurkan daun di musim kemarau, poros daun bertangkai. Daunnya tipis, cukup halus, dan jumlah daun cukup banyak. Cabang dan batang kurang besar. Batang biasanya dengan duri-duri tempel kecil (1-2 mm) yang berwarna hitam dan bertekstur cukup kasar. Dahan cukup kuat dan lentur.

- Glodogan Tiang (Polyalthia longifolia )

Vegetasi ini memiliki tinggi berkisar 15-25 m. Tajuk Glodogan Tiang berbentuk horizontal (menyebar) atau piramidal dan bermassa daun rapat. Daun hijau, halus, cukup tebal, mengilap, bentuk lanset manjang dan tidak mudah gugur. Tidak ada tangkai daun. Cabang dan batang kurang besar. Percabangannya banyak. Dahan cukup kuat dan lentur. Memiliki banyak jumlah daun. Batang dan cabang bertekstur halus.

- Jati (Tectona grandis)

Pohon besar mencapai ketinggian $45 \mathrm{~m}$. Bentuk tajuk tidak beraturan, berbentuk kubah, agak lebar dan bermassa daun kurang rapat. Berdaun besar bulat telur terbalik, tebal, dengan tangkai yang sangat pendek. Daun berukuran lebar dan sedikit berbulu, sering gugur. Cabang dan batang besar. Berbatang lurus, dengan diameter 0,9-1,5 m. Batang 
bebas cabang (clear bole) dapat mencapai 18-20 m berbatang lurus, dan sedikit cabangnya. panjang batang bebas cabang 15-20 $\mathrm{m}$ dan diameternya mencapai $220 \mathrm{~cm}$. Bentuk batang umumnya bulat dan lurus. Dahan kurang kuat tapi cukup lentur. Jumlah daun banyak.

- Jati Putih (Gmelina arborea)

Tinggi pohon dapat mencapai $45 \mathrm{~m}$. Memiliki tajuk lebar dan bermassa daun cukup rapat. Berdaun tebal dan tangkai daun panjang. Daunnya tidak mudah gugur dan cukup halus. Cabang dan batang besar. Panjang batang bebas cabang 15-20 m dan diameternya mencapai $220 \mathrm{~cm}$. Bentuk batang umumnya bulat dan lurus. Dahan cukup kuat tapi cukup lentur. Jumlah daun banyak.

- Kamboja (Plumeria rubra)

Tinggi batang berkisar 1,5-6 m. Tajuknya horizontal (menyebar) dan bermassa daun rapat. Daun berkelompok rapat pada ujung ranting, bertangkai panjang, memanjang berbentuk lanset, panjang daun $20-40 \mathrm{~cm}$, lebar $6-12,5 \mathrm{~cm}$, tebal, ujung meruncing. Tidak mudah menggugurkan daun. Jumlah daun kurang banyak. Cabang dan batang kecil. Berdaun kasar dan deciduous. Batang dan cabang bertekstur kasar. Dahan kurang kuat tapi cukup lentur.

- Kecrutan (Spathodea campanulata)

Kecrutan merupakan vegetasi rimbun. Tingginya mencapai $23 \mathrm{~m}$. Tajuk pohon ini setengah bulat dan bermassa daun cukup rapat. Daun hijau, cukup kasar dan cukup tebal. Daunnya sulit gugur. Tangkai daun cukup panjang. Vegetasi ini biasa digunakan sebagai vegetasi peneduh di halaman rumah. Dapat tumbuh baik di tempat-tempat terbuka dan kena sinar matahari langsung. Cabang dan batang kurang besar. Dahan yang kurang kuat tapi cukup lentur. Jumlah daun cukup banyak. Batang berduri. Dahan cukup kuat tapi cukup lentur.

- Kelapa (Cocos nucifera )

Tinggi kelapa berkisar 6-15 m. Tajuk bulat dan bermassa daun tidak rapat. Daun hijau tekstur kasar dan tebal. Berdaun kasar. Tidak punya tangkai daun. Jumlah daun cukup banyak. Cabang dan batang 
cukup besar, batang menyilinder, tegak, sering menekuk atau miring, abuabu muda, menggundul dan mencincin nyata dengan lampang daun yang gugur. Dahan tidak kuat tapi cukup lentur. Tekstur batang kurang kasar.

- Kelapa Sawit (Elaeis guenensis)

Tinggi kelapa sawit dapat mencapai $24 \mathrm{~m}$. Tajuk bulat. Bermassa daun tidak rapat. Daun berwarna hijau tua, kasar, tebal dan pelepah berwarna sedikit lebih muda. Daunnya tidak mudah gugur. Jumlah daun cukup banyak. Cabang dan batang kurang besar. Tidak punya tangkai daun. Penampilannya agak mirip dengan salak, hanya saja dengan duri yang tidak terlalu keras dan tajam. Dahan kurang kuat tapi cukup lentur. Tekstur batang kurang kasar.

- Kelengkeng (Dimocarpus longan)

Pohon lengkeng dapat mencapai tinggi $40 \mathrm{~m}$. Tajuk bulat dan bermassa daun rapat. Berdaun tebal, cukup kasar, tidak mudah gugur dan jumlah daun banyak. Diameter batangnya hingga sekitar $1 \mathrm{~m}$. Tangkai daun 1-20 cm. Cabang dan batang cukup besar. Dahan cukup kuat tapi cukup lentur. Batang kasar.

- Kersen (Andropon nardus)

Termasuk dalam perdu atau pohon kecil, tinggi sampai $12 \mathrm{~m}$. Tajuknya menyebar dan bermassa daun kurang rapat. Daun bertangkai pendek, cukup tebal, cukup kasar. Daunnya tidak mudah gugur dan jumlahnya banyak. Cabang dan batang cukup besar. Cabang-cabang mendatar, menggantung di ujungnya; membentuk naungan yang rindang. Ranting-ranting berambut halus bercampur dengan rambut kelenjar. Dahan kuat tapi cukup lentur. Batang cukup kasar.

- Kesumba (Bixa Arborea)

Kesumba merupakan pohon kecil dan tumbuh secara liar diantara sema belukar. Tinggi vegetasi berkisar 2-6 m. Tajuknya berbentuk horiontal (menyebar) dan bermassa daun cukup rapat. Rantingnya muda dan bersisik. Daun tunggalnya bertangkai panjang. Berdaun tebal. Helaian daunnya berbentuk bulat telur dengan ujung meruncing. Daun berbentuk bundar telur hampir seperti jantung, warna merah tua keunguan daunnya 
lebat dan bunganya indah. Cabang dan batang kecil. Dahan kurang kuat tapi cukup lentur. Daunnya sulit gugur dan jumlah daun cukup banyak. Daun cukup halus. Batang bertekstur halus.

- Ki Hujan (Samanea saman)

Merupakan tumbuhan peneduh, tingginya berkisar 10-25 m. Tajuk $\mathrm{Ki}$ Hujan bagus, berbentuk payung (dome), rimbun horizontal dan menyebar. Bermassa daun cukup rapat. Daunnya pun rimbun dimana ukuran daun yang kecil membuat sinar matahari dapat menjangkau daundaun di bagian dalam tajuk. Bentuk dahannya kecil kecil. Daunnya pun mudah gugur dan tangkai daun panjang. Cabang dan batang besar. Percabangannya pendek. Perakarannya yang sangat meluas. Bentuk dahannya kecil kecil seperti dahan putri malu.

- Mahoni (Swietenia mahagoni)

Pohon semievergreen ini ketinggiannya diantara 10-30 m. Tajuk pohon mahoni berbentuk kubah, tidak teratur kerapatan tajuknya tinggi (crown density) dan transparansi daun-daunan (foliage tranparancy) yang rendah karena sifat dari daun mahoni tebal dan banyak jumlahnya dalam setiap pohonnya. Daunnya berwarna hijau gelap, rapat dan menggugurkan daunnya pada waktu tertentu dalam satu tahun. Setelah daun gugur akan segera muncul tunas-tunas muda berwarna hijau muda. Kedudukan daun bersilangan pada ranting dengan ukuran daun lebih besar. Tangkai daun pendek dan jumlah daun banyak. Cabang dan batang besar. Diameter batangnya mencapai lebih dari $100 \mathrm{~cm}$. Percabangannya banyak. Dahan kuat tapi cukup lentur. Tekstur batang cukup kasar dan bebulu halus pada musim dingin. Batang dan cabang berduri.

- Mangga (Mangifera indica)

Mangga bisa mencapai tinggi $10 \mathrm{~m}$, membentuk tajuk yang indah berbentuk kubah, oval atau memanjang dan bermassa daun rapat. dengan daun-daun lebat. Daun tebal, tidak mudah gugur dan tangkai daun cukup panjang. Cabang dan batang besar. Tumbuhan berkayu yang mempunyai tinggi batang lebih dari $5 \mathrm{~m}$. Batang mangga tegak, cukup kasar, 
bercabang agak kuat. Dahan cukup kuat tapi cukup lentur. Jumlah daun cukup banyak. Daun halus.

- Palem Merah (Crytostachys renda)

Palem merah memiliki ketinggian 6-14 m. Tajuk bulat dan Bermassa daun tidak rapat. Daun berbentuk lanset yang tumbuh di tangkai daun. daunnya bersirip agak melengkung. Berdaun tebal dan berbulu. Cabang dan batang kecil. Batangnya berkayu, berbentuk lurus batang tidak besar. Batangnya tumbuh tegak ke atas dan jarang bercabang. Akarnya tumbuh dari pangkal batang dan berbentuk akar serabut. Tangkai daun cukup panjang. Jumlah daun cukup banyak. Batang dan cabang halus. Daun sulit gugur.

- Palem Raja (Roystonea regia)

Tinggi palem raja berkisar 25-30 $\mathrm{m}$ ditanam sebagai penghias pinggir jalan. Bermassa daun tidak rapat. Daun hijau menyirip dan cukup tebal. Tekstur daun kasar. daun vegetasi ini akan gugur atau rontok ketika sudah tua, biasanya jatuh pelepah tidak akan jauh dari pohonnya. Bentuk batangnya kokoh. Batangnya tumbuh tegak ke atas dan jarang bercabang. Akarnya tumbuh dari pangkal batang dan berbentuk akar serabut. Cabang dan batang kurang besar. Tangkai daun cukup pendek. Daunnya sulit gugur dan kasar. Batang halus. Dahan kuat tapi cukup lentur.

- $\quad$ Pinus (Pinus merkusii)

Pinus merupakan vegetasi yang tumbuh di daerah pegunungan. Tingginya dapat mencapai 20-40 m. Diameter batangnya berukuran 60-80 cm. Batang lurus dan bulat. Daun berwarna hijau tua, tekstur kasar, dan berbentuk jarum, ramping namun kaku, dan tersusun berpasangan (needles in pairs), panjang daun $16-25 \mathrm{~cm}$. Tajuknya berbentuk piramidal. Bermassa daun kurang rapat. Berdaun cukup tebal. Cabang dan batang cukup besar. Tangkai daun cukup panjang. Daunnya tidak mudah gugur. Jumlah daun banyak. Batang kasar. Dahan kuat tapi cukup lentur.

- Sengon (Albazia Falcataria)

Pohon berukuran sedang sampai besar ini tingginya sekitar 30-45 m. Tajuk vegetasi sengon berbentuk menyerupai payung dengan rimbun. 
Daun yang tidak terlalu lebat. Daun sengon tersusun majemuk menyirip ganda dengan anak daunnya kecil-kecil dan mudah rontok. panjang tangkai daun 2-8 cm. Diameter batang sekitar 70-80 cm, Bentuk batang sengon bulat dan tidak berbanir, Kulit luarnya berwarna putih atau kelabu, tidak beralur dan tidak mengelupas. Bermassa daun kurang rapat. Berdaun kurang tebal. Cabang dan batang cukup besar. Daunnya mudah gugur. Tekstur batang halus. Dahan kuat tapi cukup lentur. Daun cukup halus.

- Sikat Botol (Callistemon citrinus)

Ketinggian pohon ini sekitar 6-15 m Daun hijau lonjong menjurai. Tajuknya weeping (ranting-ranting merunduk). Daunnya sulit gugur. Bermassa daun kurang rapat. Berdaun cukup tebal. Cabang dan batang kecil. Tangkai daun cukup panjang. Jumlah daun cukup banyak. Daun cukup kasar. Batang dan cabang berduri. Dahan cukup kuat tapi cukup lentur. 


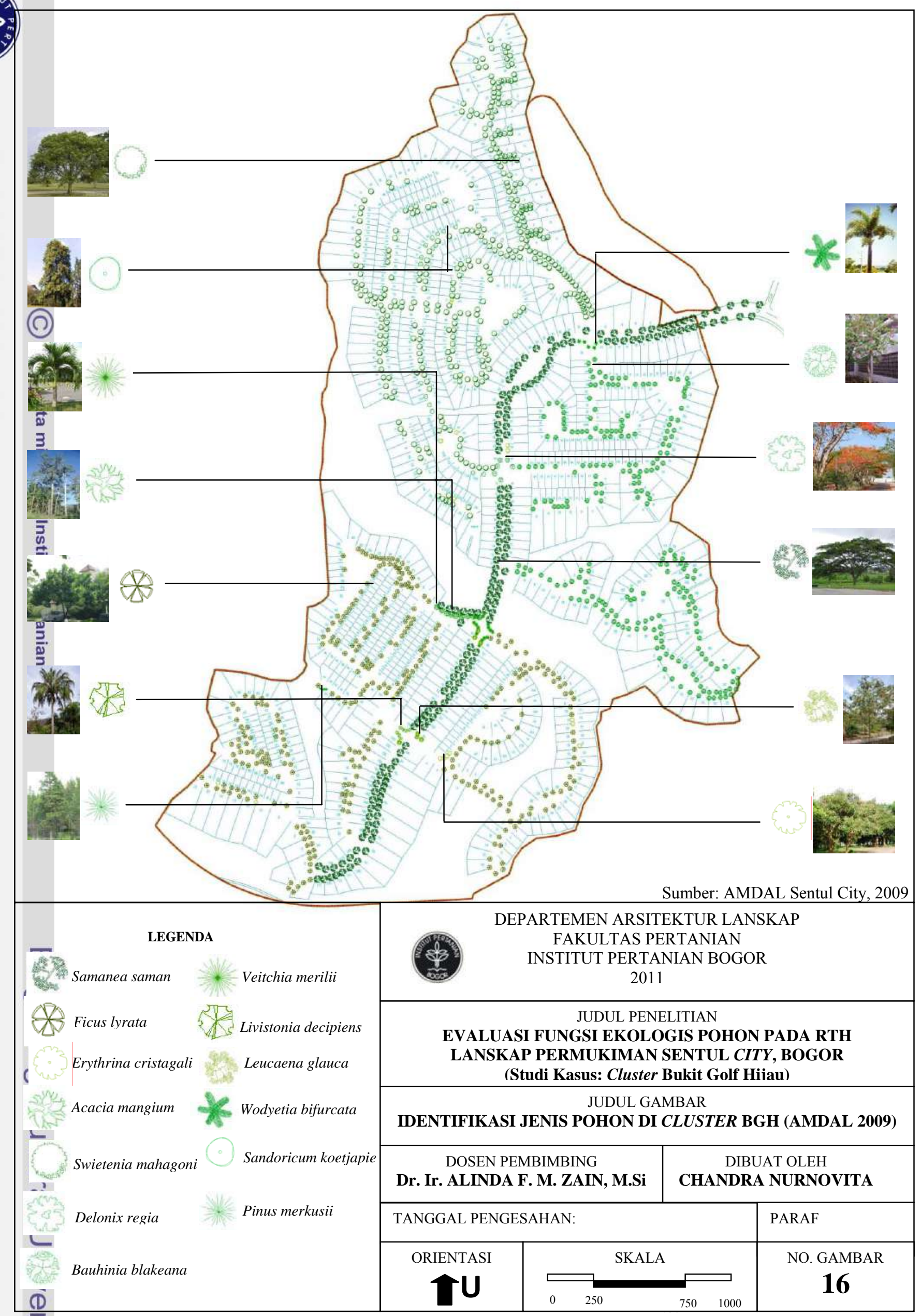




\section{Pengaruh Sosial Terhadap RTH Cluster Bukit Golf Hijau}

Evaluasi RTH lanskap permukiman harus memperhatikan kondisi sosial yang ada di sekitar lanskap tersebut. Kondisi sosial tersebut yaitu pengaruh dari penghuni yang menempati rumah-rumah di kawasan itu. Karena pendapat mereka merupakan masukkan yang berarti bagi evaluasi ini (Rahmi, 2008). Pengamatan dan analisis terhadap kondisi dan karakteristik penyediaan ruang terbuka hijau di cluster BGH Sentul City ini menunjukkan bahwa keberadaan ruang terbuka hijau di lanskap permukiman yang dibangun oleh pengembang sangat diperlukan, baik untuk memenuhi tuntutan kenyamanan penghuni maupun keseimbangan lingkungan.

Cluster BGH merupakan salah satu cluster yang berada di perumahan kelas atas. Pada umumnya jenis perumahan kelas atas cenderung lebih banyak menyediakan fasilitas ruang terbuka hijau bagi penghuninya, dibandingkan dengan lingkungan perumahan kelas menengah (Rahmi DH, 2002). Bagi pengembang lingkungan perumahan kelas atas, penyediaan fasilitas ruang terbuka hijau yang berupa taman, tempat bermain, dan jalur hijau meningkatkan nilai jual perumahan. Pada perumahan ini, kenyamanan penghuni untuk tinggal menjadi target utama, dan kenyamanan ini dapat dicapai antara lain dengan menyediakan fasilitas bagi penghuni untuk berekreasi, memiliki suasana teduh jalan lingkungan, dan keserasian dengan RTH Pocket Park.

Menurut hasil wawancara dengan pengelola Sentul City, penghuni yang menempati rumahnya di cluster ini umumnya warga kota Bogor dan Jakarta yang beralih pindah kesini. Adapula menurut mereka, penghuni hanya menempati rumahnya disini saat akhir pekan atau musim liburan. Hal ini dikarenakan mereka masih mempunyai pekerjaan di dua kota tersebut yang sulit untuk melakukan perjalanan pulang pergi, sehingga mereka menempati di saat-saat tertentu dan bertujuan untuk menghilangkan kepenatan selama bekerja di hari kerja.

Dari beberapa rumah yang ada di cluster $\mathrm{BGH}$, ada sebagian rumah yang pekarangannya sangat dipelihara dan ditanam oleh beberapa vegetasi yang memperlihatkan nilai estetika. Tetapi adapula sebagian yang dipekarangan rumahnya kurang dipelihara dan tidak ada keragaman vegetasi yang ditanam. Hal ini yang membuat pengelola memperbaiki kualitas RTH yang ada di cluster BGH 
sehingga dapat menutupi kualitas RTH masing-masing pekarangan rumah yang kurang baik.

Berdasarkan hasil wawancara oleh orang-orang yang sedang berada di kawasan ini, mereka menjawab di cluster ini kebutuhan vegetasi sudah mencukupi dan sangat beragam terutama vegetasi yang berada di RTH Pocket Park dan itu meningkatkan nilai estetika dari setiap area di cluster ini. Dari hasil wawancara juga mereka mengutarakan tidak pernah merasakan kepanasan, teduh dan merasa adem di cluster BGH dibandingkan ketika mereka keluar dari cluster tersebut, hal ini dikarenakan banyaknya pohon-pohon besar yang ditanam secara rapat sehingga sinar matahari tidak dapat menembus kerapatan antar tajuk dan daun. Selain itu di kawasan ini mereka tidak pernah mendengar kebisingan yang signifikan. Hanya kebisingan-kebisingan yang ditimbulkan dari pekerjaanpekerjaan bangunan di suatu rumah atau pendirian kavling baru yang menggunakan mesin. Jarang sekali kendaraan lalu-lalang dan menimbulkan kebisingan. Umumnya kendaraan ramai ketika disaat akhir pekan atau hari libur.

RTH yang ada disini jarang sekali digunakan oleh penghuni baik anak kecil, dewasa, atau manula untuk berkegiatan misalnya sekedar bermain, piknik, dan olahraga. Umumnya disini mereka lebih senang berkegiatan di dalam rumah. RTH yang terdapat pohon-pohon dengan tajuk lebar dan dapat berfungsi sebagai peneduh umumnya dijadikan sebagai tempat bernaung orang-orang yang bekerja disana, misalnya sebagai ojek atau pekerja bangunan untuk melepas lelah, bersantai, dan menghindari sinar matahari. Karena penggunaan yang minim dari kegiatan manusia, fungsi RTH disini sangat optimal hanya untuk meningkatkan kualitas lingkungan bukan sebagai area untuk kegiatan manusia. 


\section{Analisis Fungsi Ekologi RTH}

\section{Peredam Kebisingan}

Bukit Golf Hijau (BGH) adalah salah satu cluster di Sentul City dimana penghuninya sudah cukup banyak yang menempati rumah-rumah disini. Mayoritas penghuninya memiliki kendaraan pribadi. Karena cluster ini jauh dari jalan raya dan fasilitas umum, sehingga memiliki kendaraan pribadi merupakan suatu pertimbangan penting untuk tinggal di cluster BGH. Dengan adanya kendaraan yang lalu lalang di setiap jalan, maka kebisingan dari kendaraan tidak bisa dipungkiri. Terlebih disaat hari libur atau akhir pekan dimana penghuni menempati rumahnya atau membawa keluarga besar beristirahat sejenak menghindari hiruk pikuk kota Bogor atau Jakarta. Sehingga kendaraan semakin banyak berlalu lalang. Selain itu, di cluster ini pengelola masih mengembangkan kavling-kavling yang masih banyak berupa RTH dan akan dilakukan pembangunan rumah-rumah baru. Hal ini akan menambah kebisingan yang akan ditimbulkan dari mesin-mesin besar seperti traktor dan kegiatan dari pekerja bangunan. Oleh karena itu, hal inilah yang menjadi alasan mengapa fungsi ekologis kebisingan yang akan di evaluasi di cluster BGH. Karena pada dasarnya penghuni rumah menginginkan kondisi lingkungan rumahnya yang nyaman dan tidak bising yang ditimbulkan dari kendaraan di jalan raya atau hal-hal yang dapat menimbulkan dan ini merupakan salah satu pertimbangan seseorang dalam membeli rumah yaitu faktor kenyamanan dari kebisingan (Gambar 18.)

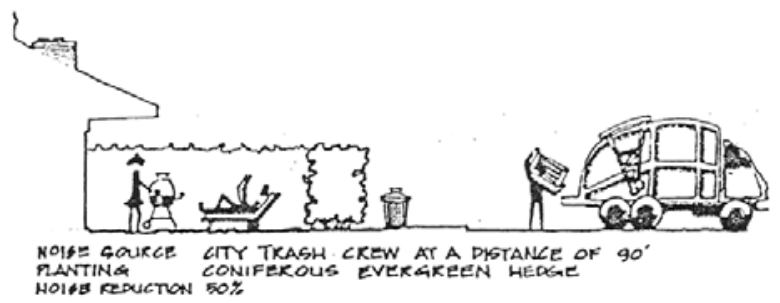

Gambar 18. Fungsi Vegetasi Mereduksi Bising di Permukiman (Sumber: Grey dan Deneke, 1978)

Intensitas kebisingan yang terukur di Sentul City menurut AMDAL Sentul City 2009 berkisar 55,2-62,4 dBA. Intensitas kebisingan terendah terjadi di Mall 
Belanova dan Intensitas kebisingan tertinggi yaitu pada lokasi Kp Pasir Maung dan Perumahan Mediterania (lokasi bersebelahan dengan cluster BGH) yang telah melebihi baku mutu tingkat kebisingan berdasarkan KEP-48/MENLH/11/1996, yang menetapkan nilai maksimum untuk daerah kawasan permukiman $55 \mathrm{dBA}$ dan Kep-829/MENKES /SK/VII/1999 menetapkan nilai yang dianjurkan untuk permukiman sehat yaitu $45 \mathrm{dBA}$ dengan nilai maksimum $55 \mathrm{dBA}$ (Tabel 11.).

Tabel 11. Baku Mutu Kebisingan Hasil Literatur

\begin{tabular}{clc}
\hline No & \multicolumn{1}{c}{ Sumber } & Baku Mutu \\
\hline 1 & Kep-48/MENLH/11/1996 & $55 \mathrm{dBA}$ \\
2 & Kep-829/MENKES /SK/VII/1999 & $45-55 \mathrm{dBA}$ \\
& Sentul City & $\mathbf{5 5 , 2 - 6 2 , 4 ~ d B A ~}$ \\
\hline
\end{tabular}

Pengelola Sentul City sebelumnya sudah memiliki kriteria jenis vegetasi peredam kebisingan di Sentul City. Vegetasi ini umumnya ditempatkan pada lokasi lingkungan perumahan dan taman budaya. Vegetasi yang ditanam untuk meredam kebisingan yang sudah ada diantaranya pohon Mahoni (Swietenia mahagoni), Pinus (Pinus merkusii), dan Kecrutan (Spathodea campanulata).

Karena sedang ada kegiatan pembuatan kavling di cluster ini, maka terdapat suara bising yang berasal dari kegiatan tersebut, misalnya bising dari suara kendaraan traktor. Hal ini tentu meresahkan penghuni cluster BGH. Terlebih, lokasi kegiatan ini tepat di pinggir jalan area BGH Raya. Oleh karena itu, diperlukan vegetasi yang dapat meredam bising yang ditimbulkan dari kegiatan ini, terlebih ditanami pada kawasan-kawasan yang berdekatan dengan kavling-kavlling kosong yang akan dibangun menjadi rumah dan sepanjang jalan raya $B G H$ Raya.

\section{Modifikasi Suhu (Peneduh)}

Seperti pada fungsi ekologis sebelumnya, alasan iklim mikro yang di analisis pada RTH ini adalah agar terciptanya suasana yang umumnya diinginkan penghuni rumah yaitu kawasan lingkungan yang teduh, adem, dan tidak terlalu kena sengatan sinar matahari. Dimana suhu pada siang hari tidak terlalu panas dan suhu pada malam hari tidak terlalu dingin. RTH dapat melindungi manusia dari panas matahari dan tekanan suhu panas serta peneduh. RTH mampu menyerap 
panas dari atmosfer yang dekat dengan permukaan tanah disekitarnya. Penghijauan memperkecil amplitudo variasi yang leih besar dari kondisi udara panas ke kondisi udara sejuk. Banyaknya pohon-pohon bertajuk lebar juga mempengaruhi iklim, karena dapat menjadi naungan yang baik untuk menghalangi panasnya sinar matahari terutama bagi pejalan kaki Dari hasil pengukuran suhu di lapang, maka munculah data suhu pada cluster (Tabel 12.)

Tabel 12. Data Suhu Udara Area di Cluster BGH

\begin{tabular}{lc}
\hline \multicolumn{1}{c}{ Area } & Suhu $\left(\mathbf{(}^{\mathbf{}} \mathbf{C}\right)$ \\
\hline BGH Raya & 29 \\
Puncak & 30 \\
Bukit & 34 \\
Lembah & 26 \\
Gunung & 28 \\
\hline Bukit Golf Hijau & 29,4 \\
\hline Di bawah naungan pohon & 26 \\
\hline
\end{tabular}

Berdasarkan data suhu di setiap masing-masing area, yang memiliki nilai suhu tertinggi berada di area bukit dengan suhu mencapai $34^{\circ} \mathrm{C}$ dan yang memiliki nilai suhu terendah berada di area lembah. Menurut Laurie (1986), iklim ideal bagi manusia adalah udara yang bersih dengan suhu $27-28^{\circ} \mathrm{C}$. Kemudian menurut Bianpoen et al. (1989), daerah kenyamanan (comfort zone) bagi badan manusia berada pada suhu 25,6-26,7 ${ }^{\circ}$. Dan berdasarkan Kep-829/MENKES /SK/VII/1999, suhu udara yang nyaman bagi lingkungan permukiman sehat yaitu sekitar $18-30^{\circ} \mathrm{C}$. Dari ketiga literatur tersebut disimpulkan bahwa cluster BGH masih berada di daerah nyaman dengan suhu $29,4^{\circ} \mathrm{C}$, dan area yang termasuk kawasan dengan suhu ideal yaitu area BGH Raya, lembah dan gunung.

Di area lembah dan gunung vegetasi yang mendominasi yaitu Biola Cantik (Ficus lyrata) dan di area BGH Raya didominasi oleh vegetasi Ki Huja (Samanaea saman). Iini membuktikan bahwa keberadaan vegetasi ini mampu mereduksi suhu yang tinggi dan dapat memberikan kenyamanan di kedua area ini. Selain itu di area ini terutama di area lembah, penghuni masih relatif sedikit belum dipenuhi oleh rumah, sehingga RTH yang berupa kavling masih banyak dan ini mempengaruhi suhu udara di area ini. Pada area dengan suhu tertinggi yaitu area bukit, vegetasi yang mendominasi yaitu Mahoni (Swietenia mahagoni). Secara fisik vegetasi ini sudah cukup memenuhi kriteria sebagai vegetasi 
peneduh, namun seiring dengan banyaknya rumah yang sudah dihuni tidak akan sebanding dengan RTH yang berupa kavling, sehingga jumlah vegetasi di area ini relatif sedikit. Oleh karena itu, suhu udara belum bisa direduksi dengan baik. Pada area lembah, suhu disini rendah, hal ini dipengaruhi oleh jumlah vegetasi yang berlebih sehingga sinar matahari kurang masuk kedalam area ini dimana kelembaban akan bertambah. Selain itu pengaruh dari jarak kerapatan antar vegetasi yan rapat yang akhirnya sinar matahari sulit masuk dan tanah-tanah menjadi lembab dan mengurangi kesuburan tanah.

Pengelola Sentul City sebelumnya sudah memiliki kriteria jenis vegetasi modifikasi suhu (peneduh) di Sentul City. Vegetasi ini umumnya ditempatkan di semua jenis RTH. Vegetasi yang ditanam untuk modifikasi suhu (peneduh) yang sudah ada diantaranya pohon Beringin (Ficus benjamina), Bunga Kupu-Kupu (Bauhinia blakeana), Kerai Payung (Filicium decipiens), Biola Cantik (Ficus lyrata), dan Sawo Kecik (Manilkara kauki).

Kondisi iklim di cluster BGH kemungkinan berubah akibat adanya kegiatan pembuatan kavling baru. Karena dengan adanya kegiatan tersebut, maka RTH yang ada di cluster BGH akan menurun dan jumlah vegetasi yang ada di cluster ini juga berkurang. Hal ini akan mempengaruhi suhu disana. Dari hasil inventarisasi lapang, tampak berbeda sebelum dan sesudah kegiatan. Sebelumnya area tampak rimbun dengan pepohonan sekarang menjadi gersang tanpa pepohonan. Lokasi tersebut tidak lagi teduh,rimbun dan sinar matahari menyengat langsung tanpa ada pantulan, sehingga sangat mengganggu bagi penghuni, terutama penghuni rumah yang berhadapan dengan lokasi tersebut.

Cluster BGH memiliki kelebihan dibandingkan cluster lain karena memiliki RTH terluas. Hal ini jelas mempengaruhi suhu di kawasan ini. Karena semakin banyak RTH di suatu wilayah terutama permukiman, maka suhu di wilayah tersebut menurun dan kemudian akan tercipta kenyamanan bagi pengguna. Berdasarkan hasil wawancara dari pengguna cluster $\mathrm{BGH}$, dapat disimpulkan bahwa mereka merasa nyaman tinggal disana, karena suasananya yang teduh dan sinar matahari yang datang tidak terlalu menyengat karena terhalang oleh tajuk-tajuk pohon. 


\section{Kontrol Kelembaban Udara}

Kelembaban udara merupakan salah satu unsur penting dalam mengontrol iklim mikro, karena kelembaban udara juga menentukan kenyaman yang diperlukan bagi penghuni rumah. Dari hasil data primer di lapang dengan pengukuran menggunakan thermo hygrometer, maka muncul data kelembaban udara yang merupakan hasil selisih suhu bola kering dengan suhu bola basah. Berikut data kelembaban udara di masing-masing area berdasarkan tabel Hygrometer (pada lampiran)

Tabel 13. Data Kelembaban Udara Area di Cluster BGH

\begin{tabular}{lccc}
\hline \multicolumn{1}{c}{ Area } & TBK $\left(\mathbf{(}^{\mathbf{0}} \mathbf{C}\right)$ & TBB $\left({ }^{\mathbf{0}} \mathbf{C}\right)$ & RH (\%) \\
\hline BGH Raya & 29 & 26 & 78 \\
Puncak & 30 & 25 & 65 \\
Bukit & 34 & 28 & 62 \\
Lembah & 26 & 26 & 100 \\
Gunung & 28 & 25 & 77 \\
\hline Bukit Golf Hijau & 29,4 & 26 & 76,4 \\
\hline
\end{tabular}

Ket: $\quad$ TBK: Suhu bola kering

TBB: Suhu bola basah

RH: Kelembaban Udara, dimana RH $=\mathrm{TBK}-\mathrm{TBB}$

Hasil nilai kelembaban yang diperoleh dari tabel diatas memperoleh kesimpulan bahwa kelembaban udara paling tinggi yang diterima yaitu berada di area lembah dengan hasil $100 \%$, dan yang terendah berada pada area bukit dengan hasil $62 \%$, dan ketiga area yang lain yaitu area BGH Raya (78\%), Puncak (65\%), dan Gunung (77\%) berada di antaranya.

Menurut Laurie (1986), kelembaban ideal bagi manusia adalah 40-75\% dengan udara yang tidak terperangkap dan tidak berupa angin kencang, dan keterlindungan terhadap hujan. Sedangkan relative humidity $(\mathrm{RH})$ daerah kenyamanan (comfort zone) bagi badan manusia adalah 45-50\% (Bianpoen et al.,1989), dan berdasarkan Kep-829/MENKES /SK/VII/1999, Kelembaban udara yang nyaman bagi lingkungan permukiman yaitu sekitar 40-70\%. Dari ketiga literatur tersebut maka disimpulkan bahwa kelembaban udara cluster BGH berada melebihi daerah kenyamanan dengan kelembaban udara 76,4\%.

Area yang memiliki nilai kelembaban udara berada pada kisaran ideal yaitu 40 sampai $70 \%$ diantaranya adalah area puncak dan bukit. Kedua area ini memiliki vegetasi dominan yaitu Bunga Kupu-Kupu dan Mahoni. Kedua vegetasi 
ini tidak terlalu memiliki kriteria dalam mengontrol kelembaban udara, tapi dari topografi semua area, area puncak dan bukit memiliki penghuni mayoritas paling banyak dibandingkan dengan yang lain. Sehingga penanaman vegetasi di kedua area tersebut tidak berlebihan, sehingga di daerah ini sinar matahari yang masuk cukup ideal karena kanopi yang menghalangi masuknya sinar matahari sudah sesuai. Maka dikedua daerah ini kelembaban udaranya ideal, penghuni tidak merasa lembab dan tidak kering berada disini.

\section{Penahan Angin}

Di Indonesia kecepatan angin di siang hari bisa lebih kencang dibandingkan malam hari. Di beberapa lokasi bahkan pada malam hari tidak terjadi gerakan udara yang signifikan. Udara yang bergerak dekat dengan permukaan tanah akan mempunyai kecepatan nol dan kemudian meningkat terhadap ketinggian. Kecepatan angin juga dipengaruhi oleh kontur dari permukaan, Di daerah perkotaan dengan banyak rumah, apartemen dan perkantoran bertingkat, kecepatan angin akan rendah.

Kecepatan angin di daerah iklim tropis panas lembab umumnya rendah. Kecepatan angin yang nikmat dalam ruangan adalah 0,1-0,15 $\mathrm{m} /$ detik dan Kecepatan angin dibawah pohon lebih rendah daripada di sekitarnya.

Tabel 14. Data Kecepatan Angin Tahun 2008-2009

\begin{tabular}{lcc}
\hline \multirow{2}{*}{ Bulan } & \multicolumn{2}{c}{ Kecepatan Per Bulan dalam 1 tahun } \\
\cline { 2 - 3 } & $\mathbf{2 0 0 8}$ & $\mathbf{2 0 0 9}$ \\
\hline JAN & 3,1 & 2,9 \\
PEB & 3,2 & 3,5 \\
MAR & 2,5 & 2,9 \\
APR & 2,3 & 2,3 \\
MEI & 2,2 & 2,2 \\
JUN & 2,0 & 2,1 \\
JUL & 2,4 & 2,4 \\
AGS & 2,2 & 2,4 \\
SEPT & 2,6 & 2,7 \\
OKT & 2,4 & 2,4 \\
NOP & 2,8 & 2,6 \\
DES & 2,8 & 2,3 \\
\hline JML & 30,5 & 30,7 \\
RATA2 & 2,5 & 2,6 \\
\hline Kec Angin
\end{tabular}

Kec. Angin : Knots 
Dari Tabel data sekunder diatas, maka dapat disimpulkan bahwa kecepatan angin pada tahun 2008-2009 perbulannya termasuk kategori lemah. Arah angin berasal dari barat. Hal ini juga berkaitan dengan analisis dari fungsi ekologis kelembaban udara di cluster BGH, diketahui bahwa kelembaban udara disini relatif tinggi. Semakin tinggi kelembaban udara maka semakin lemah kecepatan angin di kawasan tersebut. Berdasarkan skala beaufort, kecepatan angin di cluster BGH termasuk dalam skala 1 dengan tingkatan teduh (1-3 Knots), dengan ilustrasi keadaan di darat seperti di bawah ini (Gambar 19.).

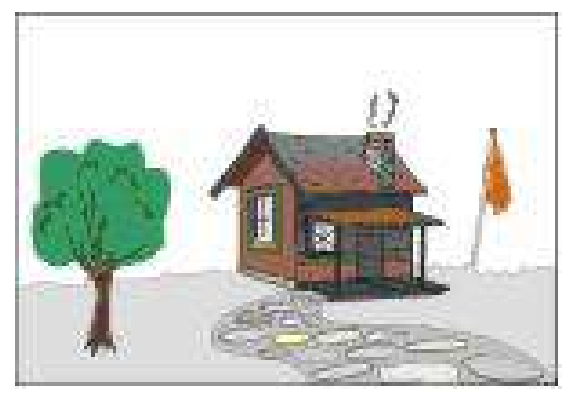

Gambar 19. Keadaan di Darat pada Skala Beaufort 1

Karena pohon dapat menghalangi datangnya sinar matahari, sehingga area di bawah kanopi pohon lebih dingin sebanyak $25^{\circ} \mathrm{F}\left(14^{\circ} \mathrm{C}\right)$ daripada di area terbuka (Grey dan Deneke, 1978). Selain itu menurut Grey dan Deneke (1978), penanaman pohon konifer pada kemiringan mempengaruhi pergerakan udara dingin yang senormalnya mengalir dari titik terendah.

Pengelola Sentul City sebelumnya sudah memiliki kriteria jenis vegetasi penahan angin di Sentul City. Vegetasi ini umumnya ditempatkan di semua jenis RTH. Vegetasi yang ditanam untuk penahan angin yang sudah ada diantaranya pohon Dadap Merah (Erythrina cristagali), Bungur (Lagerstromia indica), Beringin Karet (Ficus elastica), dan Bintaro (Cerbera odollam).

\section{Evaluasi Aspek Fungsi Ekologis Vegetasi RTH Cluster Bukit Golf Hijau}

Penilaian terhadap beberapa fungsi vegetasi lanskap permukiman berdasarkan kriteria masing-masing fungsi dengan jumlah yang berbeda, yaitu (1) kategori sangat baik, (2) kategori baik, (3) kategori sedang, (4) kategori buruk. Penilaian dibuat dalam bentuk tabel dan deskriptif setiap fungsinya. 


\section{Peredam Kebisingan}

Kebisingan merupakan suara yang tidak diinginkan, dalam hal ini berarti penghuni rumah yang tidak menginginkan suara bising dari kendaraan bermotor dan pekerjaan bangunan yang kerap terjadi di kawasan ini. Hasil identifikasi jenis vegetasi yang ada di cluster Bukit Golf Hijau (BGH) ini kemudian akan dinilai kriteria fisiknya (Tabel 15.).

Tabel 15. Kritteria Penilaian Aspek Fungsi Peredam Kebisingan

\begin{tabular}{|c|c|c|c|c|c|c|c|c|c|}
\hline \multirow[t]{2}{*}{ No } & \multirow[t]{2}{*}{ Nama Latin } & \multirow[t]{2}{*}{ Nama Lokal } & \multicolumn{5}{|c|}{$\begin{array}{c}\text { Kriteria Fungsi } \\
\text { Kebisingan }\end{array}$} & \multirow{2}{*}{$\begin{array}{c}\text { Skor } \\
(\%)\end{array}$} & \multirow[t]{2}{*}{ Kategori } \\
\hline & & & K1 & K2 & K3 & K4 & K5 & & \\
\hline 1 & Acasia auriculiform & Akasia & 4 & 3 & 4 & 2 & 4 & 85 & SB \\
\hline 2 & Acasia mangium & Akasia Daun Lebar & 4 & 3 & 3 & 3 & 3 & 80 & $\mathrm{BA}$ \\
\hline 3 & Araucaria heterophylla & Cemara Norflok & 3 & 4 & 4 & 1 & 2 & 70 & $\mathrm{BA}$ \\
\hline 4 & Bauhinia blakeana & Bunga kupu-Kupu & 2 & 2 & 2 & 2 & 3 & 55 & KB \\
\hline 5 & Bixa Arborea & Kesumba & 3 & 4 & 1 & 2 & 4 & 70 & BA \\
\hline 6 & Callistemon citrinus & Sikat Botol & 2 & 3 & 1 & 3 & 2 & 55 & $\mathrm{~KB}$ \\
\hline 7 & Cerbera odollam & Bintaro & 3 & 4 & 3 & 2 & 4 & 80 & BA \\
\hline 8 & Cocos nucifera & Kelapa & 1 & 4 & 3 & 1 & 1 & 50 & $\mathrm{~KB}$ \\
\hline 9 & Crytostachys renda & Palem Merah & 1 & 4 & 1 & 3 & 2 & 55 & $\mathrm{~KB}$ \\
\hline 10 & Dimocarpus longan & Kelengkeng & 4 & 4 & 3 & 3 & 2 & 80 & BA \\
\hline 11 & Elaeis guenensis & Kelapa Sawit & 1 & 4 & 2 & 1 & 1 & 45 & $\mathrm{~KB}$ \\
\hline 12 & Erythrina cristagali & Dadap Merah & 2 & 1 & 2 & 3 & 3 & 55 & $\mathrm{~KB}$ \\
\hline 13 & Ficus benjamina & Beringin & 4 & 4 & 4 & 3 & 3 & 90 & SB \\
\hline 14 & Ficus elastica & Beringin Karet & 4 & 4 & 4 & 2 & 2 & 85 & SB \\
\hline 15 & Ficus lyrata & Biola Cantik & 4 & 4 & 2 & 4 & 3 & 85 & SB \\
\hline 16 & Gmelina sp. & Jati Putih & 3 & 4 & 4 & 4 & 3 & 90 & SB \\
\hline 17 & Mangifera indica & Mangga & 4 & 4 & 4 & 3 & 2 & 85 & SB \\
\hline 18 & Muntingia calabura & Kersen & 2 & 3 & 3 & 3 & 4 & 75 & BA \\
\hline 19 & Paraserianthes falcataria & Sengon & 2 & 2 & 3 & 4 & 4 & 75 & BA \\
\hline 20 & Pinus merkusii & Pinus & 2 & 3 & 3 & 3 & 3 & 70 & BA \\
\hline 21 & Plumeria rubra & Kamboja & 2 & 4 & 1 & 4 & 1 & 60 & $\mathrm{~KB}$ \\
\hline 22 & Polyalthia longifolia & Glodogan Tiang & 4 & 3 & 2 & 1 & 2 & 60 & $\mathrm{~KB}$ \\
\hline 23 & Psidium guajava & Jambu & 2 & 4 & 3 & 2 & 1 & 60 & $\mathrm{~KB}$ \\
\hline 24 & Pterocarpus indicus & Angsana & 4 & 3 & 4 & 2 & 4 & 85 & SB \\
\hline 25 & Roystonea regia & Palem Raja & 1 & 3 & 2 & 2 & 2 & 50 & KB \\
\hline 26 & Samanea saman & Ki Hujan & 3 & 1 & 4 & 4 & 3 & 75 & BA \\
\hline 27 & Spathodea campanulata & Kecrutan & 3 & 3 & 2 & 3 & 4 & 75 & BA \\
\hline
\end{tabular}


Tabel 15. Lanjutan

\begin{tabular}{|c|c|c|c|c|c|c|c|c|}
\hline 28 & Swietenia mahagoni & Mahoni & 4 & 4 & 2 & 2 & 80 & BA \\
\hline \multirow[t]{2}{*}{29} & Tectona grandis & Jati & 2 & 4 & 2 & 3 & 75 & BA \\
\hline & Rata-Rata & & & & & & 70,86 & BA \\
\hline Ket: & $\begin{array}{l}\text { K1: Tajuk ra } \\
\text { K2: Berdaur } \\
\text { K3: Cabang } \\
\text { K4: Mempu } \\
\text { K5: Daun ri }\end{array}$ & $\begin{array}{l}\text { dan massa } \\
\text { al } \\
\text { batang be } \\
\text { tangkai-ta } \\
\text { g dan ring }\end{array}$ & & & & & & \\
\hline \multicolumn{2}{|c|}{ Pembobotan penilaian: } & $\begin{array}{l}\text { Nilai 4: } \\
\text { Nilai 3: } \\
\text { Nilai 2: } \\
\text { Nilai 1: }\end{array}$ & $\begin{array}{l}(\mathrm{SB}) \\
(\mathrm{KB})\end{array}$ & \multicolumn{5}{|c|}{$\begin{array}{l}\text { bila } \geq 81 \% \text { kriteria terpenuhi } \\
\text { bila } 61-80 \% \text { kriteria terpenuhi } \\
\text { bila } 41-60 \% \text { kriteria terpenuhi } \\
\text { bila } \leq 40 \% \text { kriteria terpenuhi }\end{array}$} \\
\hline
\end{tabular}

Berdasarkan penilaian karakter fisik setiap jenis vegetasi di cluster BGH, maka vegetasi yang termasuk kategori sangat baik dalam pemenuhan kriteria fisik yaitu, Beringin (Ficus benjamina), Jati Putih (Gmelina arborea), Akasia (Acacia auriculiform), Angsana (Pterocarpus indicus), Beringin Karet (Ficus elastica), Biola Cantik (Ficus lyrata), Mangga (Mangifera indica) dengan skor 85\% dan $90 \%$ dan persentase sekitar $24,14 \%$ dari keseluruhan jenis vegetasi. Hal ini berarti kriteria fisik yang ada pada vegetasi sudah sesuai dengan semua kriteria fungsi ekologis dalam menyerap kebisingan. Jati Putih (Gmelina arborea), Akasia (Acacia auriculiform), Beringin karet (Ficus elastica), Biola Cantik (Ficus lyrata) termasuk vegetasi dominan di cluster BGH ini, sedangkan Beringin (Ficus benjamina), Angsana (Pterocarpus indicus), Mangga (Mangifera indica) termasuk jenis vegetasi minoritas. Vegetasi-vegetasi ini umumnya ditanam pada RTH berupa kavling kosong dan RTH di area yang khusus untuk kawasan RTH, seharusnya vegetasi-vegetasi ini ditanam juga di RTH sepanjang jalan lingkungan berada di setiap jalan cluster BGH agar suara kendaraan bermotor tidak terdengar bisingnya ke dalam rumah penghuni cluster BGH.

Sedangkan yang termasuk kategori baik yaitu jenis vegetasi Kelengkeng (Dimocarpus longan), Mahoni (Swietenia mahagoni), Bintaro (Cerbera odollam), Jati (Tectona grandis), Kecrutan (Spathodea campanulata), Ki Hujan (Samanea saman), Sengon (Albazia Falcataria), Akasia Daun Lebar (Akasia mangium), , Kesumba (Bixa Arborea), Pinus (Pinus merkusii), Kersen (Muntingia calabura), Cemara Norflok (Araucaria heterophylla), dengan skor 70\%, 75\%, dan 80\%. Persentase keragaman yang sesuai sekitar $41,38 \%$ dari keseluruhan ragam 
vegetasi. Hal ini berarti kriteria fisik pada vegetasi hanya setengahnya yang sudah sesuai dengan kriteria fungsi ekologis dalam menyerap kebisingan. Umumnya vegetasi-vegetasi pada kriteria ini ditanam di RTH berupa kavling kosong, RTH di area yang khusus untuk kawasan RTH, dan di RTH sepanjang jalan lingkungan. Ki Hujan (Samanea saman) yang merupakan vegetasi yang ditanam sepanjang jalan BGH Raya walaupun termasuk kategori sedang tetapi dengan jumlah yang ditanam mayoritas maka sudah bisa mengurangi kebisingan di sepanjang jalan raya.

Yang termasuk kriteria kurang baik yaitu vegetasi Glodogan Tiang (Polyalthia longifolia), Jambu (Psidium guajava), Bunga kupu-Kupu (Bauhinia blakeana), Kamboja (Plumeria rubra), Dadap Merah (Erythrina cristagali), Palem Merah (Crytostachys renda), Sikat Botol (Callistemon citrinus), Kelapa (Cocos nucifera), Palem Raja (Roystonea regia), Kelapa Sawit (Elaeis guenensis), dengan skor $60 \%, 55 \%, 50 \%$, dan $45 \%$. Persentase keragaman jenis vegetasi yang sesuai kriteria fungsi ekologis ini sekitar $34,48 \%$. Hal ini berarti kriteria fisik pada vegetasi hanya beberapa atau sedikit yang sudah sesuai dengan kriteria fungsi ekologis dalam menyerap kebisingan. Umumnya vegetasi-vegetasi ini ditanam di RTH Pocket Park sehingga fungsi utamanya bukan untuk menyerap kebisingan, tetapi untuk fungsi estetika. Dan dari hasil penilaian tidak ada jenis vegetasi yang masuk kategori buruk, ini berarti kriteria fisik tidak sesuai dengan kriteria fungsi ekologis dalam menyerap kebisingan. Pada dasarnya setiap jenis vegetasi memiliki efektivitas yang berbeda dalam mereduksi kebisingan karena adanya perbedaan karakter dari tiap jenis vegetasi tersebut.

Berdasarkan penilaian kriteria fungsi RTH dalam meredam kebisingan maka jenis keragaman vegetasi di cluster BGH memiliki kriteria yang sebanding antara yang sudah sesuai dan belum sesuai. Umumnya jenis vegetasi yang sudah memenuhi kriteria in adalah jenis pohon besar dengan kriteria fisik tajuk rapat dan massa daun rapat, memiliki daun tebal, cabang dan batang besar, mempunyai tangkai-tangkai daun, daun rindang dan ringan. Sedangkan jenis vegetasi yang kurang sesuai dengan kriteria fungsi peredam kebisingan yaitu jenis vegetasi pohon kecil sampai sedang, memiliki daun tipis dan massa daun kurang padat. 
Penempatan vegetasi yang dirasa sesuai yaitu pada RTH berupa kavling kosong, RTH di area yang khusus untuk kawasan RTH, dan di RTH sepanjang jalan lingkungan berada di setiap jalan cluster BGH. Hal ini dikarenakan jenis vegetasi yang berada di RTH tersebut sudah memiliki kriteria fisik yang sesuai dengan fungsi peredam kebisingan. Lain halnya dengan vegetasi di RTH Pocket Park yang kriteria fisiknya belum memenuhi fungsi peredam kebisingan. Sehingga penempatan vegetasi RTH ini dirasa belum sesuai dengan kriteria fungsi peredam kebisingan. RTH yang sudah memenuhi kebutuhan fungsinya dalam meredam kebisingan yaitu sekitar $177.953 \mathrm{~m}^{2}$ dan yang belum memenuhi sekitar $14.567 \mathrm{~m}^{2}$ (Gambar 20.). 


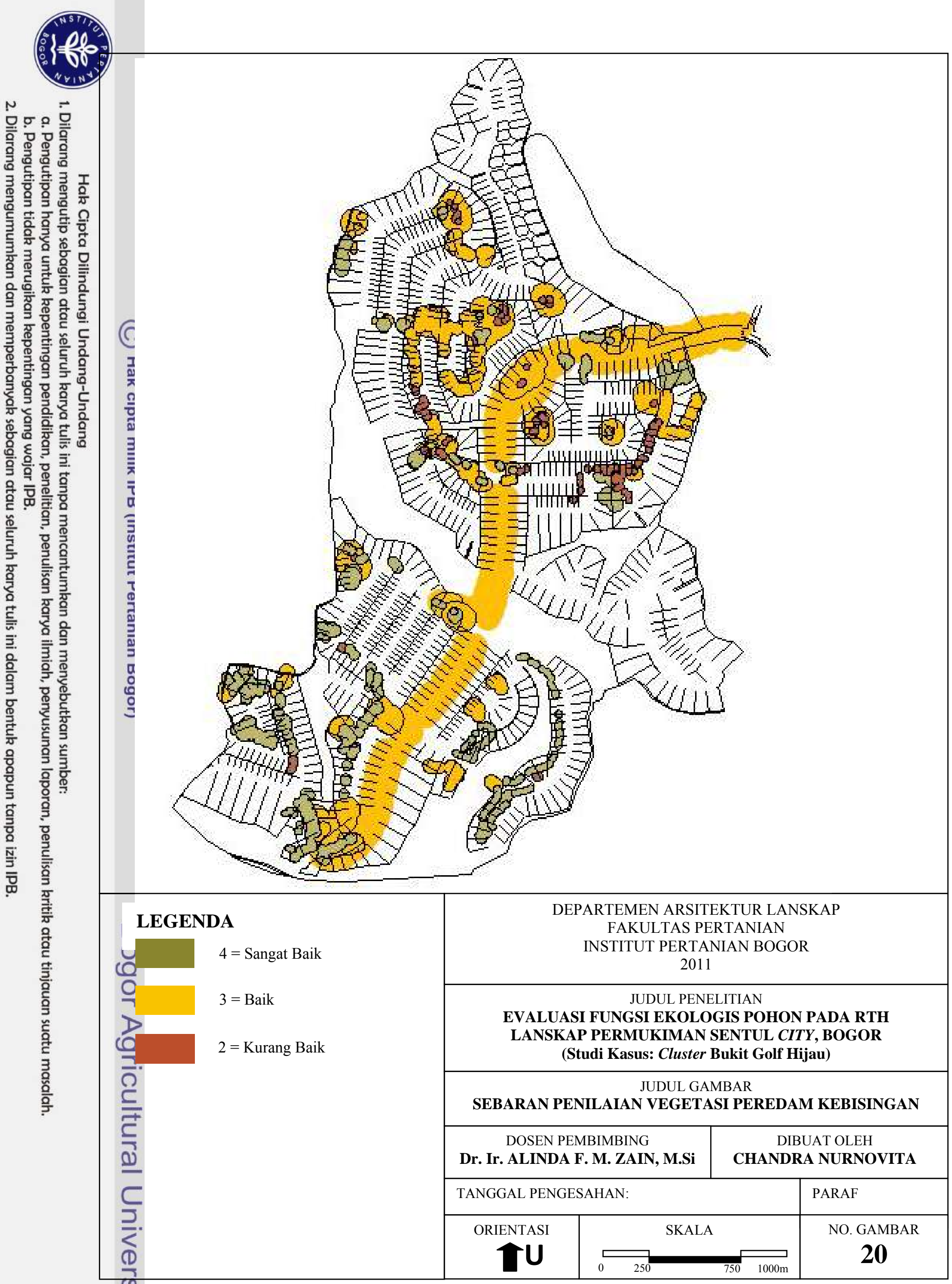




\section{Modifikasi Suhu (Peneduh)}

Cluster BGH merupakan Cluster yang dominan dengan pohon-pohon tinggi, sehingga kawasan ini termasuk salah satu kawasan dengan suhu rendah di Sentul City, oleh karena itu Cluster ini cukup diminati bagi orang-orang untuk mempunyai rumah di kawasan ini. Dari hasil penilaian, maka muncul kriteria kesesuaian fisik vegetasi terhadap kriteria fungsi ekologis modifikasi suhu (peneduh) (Tabel 16.).

Tabel 16. Kriteria Penilaian Aspek Fungsi Modifikasi Suhu (Peneduh)

\begin{tabular}{|c|c|c|c|c|c|c|c|c|c|}
\hline \multirow{2}{*}{ No } & \multirow{2}{*}{ Nama Latin } & \multirow{2}{*}{ Nama Lokal } & \multicolumn{5}{|c|}{ Kriteria Fungsi Peneduh } & \multirow{2}{*}{$\begin{array}{l}\text { Skor } \\
(\%)\end{array}$} & \multirow{2}{*}{ Kategori } \\
\hline & & & k1 & k2 & k3 & k4 & k5 & & \\
\hline 1 & Acasia auriculiform & Akasia & 4 & 4 & 4 & 4 & 3 & 95 & SB \\
\hline 2 & Acasia mangium & Akasia Daun Lebar & 4 & 3 & 2 & 4 & 3 & 80 & BA \\
\hline 3 & Araucaria heterophylla & Cemara Norflok & 4 & 2 & 3 & 2 & 4 & 75 & $\mathrm{BA}$ \\
\hline 4 & Bauhinia blakeana & Bunga kupu-Kupu & 2 & 4 & 2 & 3 & 2 & 65 & BA \\
\hline 5 & Bixa Arborea & Kesumba & 1 & 4 & 3 & 4 & 4 & 80 & BA \\
\hline 6 & Callistemon citrinus & Sikat Botol & 2 & 4 & 2 & 2 & 3 & 65 & BA \\
\hline 7 & Cerbera odollam & Bintaro & 2 & 4 & 3 & 4 & 4 & 85 & SB \\
\hline 8 & Cocos nucifera & Kelapa & 2 & 4 & 1 & 4 & 4 & 75 & BA \\
\hline 9 & Crytostachys renda & Palem Merah & 2 & 1 & 1 & 2 & 2 & 40 & $\mathrm{BU}$ \\
\hline 10 & Dimocarpus longan & Kelengkeng & 4 & 4 & 4 & 3 & 4 & 95 & SB \\
\hline 11 & Elaeis guenensis & Kelapa Sawit & 3 & 2 & 1 & 4 & 4 & 70 & BA \\
\hline 12 & Erythrina cristagali & Dadap Merah & 2 & 4 & 2 & 4 & 1 & 65 & BA \\
\hline 13 & Ficus benjamina & Beringin & 3 & 4 & 4 & 3 & 4 & 80 & $\mathrm{BA}$ \\
\hline 14 & Ficus elastica & Beringin Karet & 4 & 4 & 3 & 4 & 4 & 95 & SB \\
\hline 15 & Ficus lyrata & Biola Cantik & 3 & 4 & 4 & 4 & 4 & 95 & SB \\
\hline 16 & Gmelina sp. & Jati Putih & 4 & 4 & 3 & 4 & 4 & 95 & SB \\
\hline 17 & Mangifera indica & Mangga & 4 & 3 & 4 & 4 & 4 & 95 & SB \\
\hline 18 & Muntingia calabura & Kersen & 2 & 4 & 2 & 4 & 3 & 75 & BA \\
\hline 19 & Paraserianthes falcataria & Sengon & 4 & 4 & 2 & 4 & 2 & 80 & BA \\
\hline 20 & Pinus merkusii & Pinus & 4 & 2 & 2 & 4 & 3 & 75 & BA \\
\hline 21 & Plumeria rubra & Kamboja & 1 & 4 & 4 & 3 & 4 & 80 & BA \\
\hline 22 & Polyalthia longifolia & Glodogan Tiang & 3 & 3 & 4 & 2 & 3 & 75 & BA \\
\hline 23 & Psidium guajava & Jambu & 2 & 3 & 2 & 3 & 4 & 70 & BA \\
\hline 24 & Pterocarpus indicus & Angsana & 4 & 4 & 4 & 4 & 3 & 95 & SB \\
\hline 25 & Roystonea regia & Palem Raja & 3 & 2 & 1 & 3 & 3 & 60 & $\mathrm{~KB}$ \\
\hline 26 & Samanea saman & Ki Hujan & 4 & 4 & 3 & 4 & 1 & 80 & BA \\
\hline
\end{tabular}


Tabel 16. Lanjutan

\begin{tabular}{cccccccccc}
\hline 27 & Spathodea campanulata & Kecrutan & 3 & 4 & 3 & 4 & 3 & 75 & BA \\
\hline 28 & Swietenia mahagoni & Mahoni & 3 & 4 & 4 & 4 & 4 & 95 & SB \\
\hline 29 & Tectona grandis & Jati & 4 & 4 & 2 & 3 & 4 & 85 & SB \\
\hline \multicolumn{1}{c}{ Rata-Rata } & & & & & 79,14 & BA \\
\hline Ket: & K1: Pohon relatif tinggi & & & & & \\
& K2: Bentuk tajuk spreading, bulat, dome, irregular & & & \\
K3: Bermassa daun padat & & & & & \\
K4: Berkanopi besar dan lebar & K5: Daun tebal & & & & \\
Pembobotan penilaian: & Nilai 4: Sangat Baik (SB) & bila $\geq 81 \%$ kriteria terpenuhi \\
& Nilai 3: Baik (BA) & bila 61-80\% kriteria terpenuhi \\
& Nilai 2: kurang baik (KB) & bila 41-60\% kriteria terpenuhi \\
& Nilai 1: Buruk (BU) & bila $\leq 40 \%$ kriteria terpenuhi
\end{tabular}

Berdasarkan penilaian karakter fisik yang sesuai dengan karakter fungsi peneduh, maka yang termasuk kategori sangat baik yaitu jenis vegetasi Akasia (Acacia auriculiform), Bintaro (Cerbera odollam), Kelengkeng (Dimocarpus longan), Beringin Karet (Ficus elastica), Biola Cantik (Ficus lyrata), Jati Putih (Gmelina sp.), Mangga (Mangifera indica), Angsana (Pterocarpus indicus), Mahoni (Swietenia mahagoni), dan Jati (Tectona grandis). Dengan skor 85\% dan 95\%, sedangkan persentase dari keseluruhan jenis vegetasi yang sesuai sekitar $34,48 \%$. Dari hasil inventarisasi, jenis vegetasi dominan yang sudah berkategori sangat baik yaitu Akasia (Acacia auriculiform), Biola Cantik (Ficus lyrata), Mahoni (Swietenia mahagoni), dan Jati (Tectona grandis). Sedangkan vegetasi minoritas ditanam sedikit yaitu Bintaro (Cerbera odollam) dan Kelengkeng (Dimocarpus longan). Semua vegetasi yang masuk dalam kategori ini berada di RTH berupa kavling kosong dan RTH di area yang khusus untuk kawasan RTH, hal ini sudah sesuai dengan fungsinya dalam menurunkan suhu. Dari beberapa jenis vegetasi di kategori ini, umumnya termasuk dalam jenis pohon besar yang mampu menyerap panas dari pancaran sinar matahari dan memantulkannya.

Yang termasuk dalam kategori baik dalam kesesuaian terhadap karakter fungsi peneduh yaitu vegetasi Akasia Daun Lebar (Akasia mangium), Cemara Norflok (Araucaria heterophylla), Bunga kupu-Kupu (Bauhinia blakeana), Kesumba (Bixa Arborea), Sikat Botol (Callistemon citrinus), Kelapa (Cocos nucifera), Kelapa Sawit (Elaeis guenensis), Dadap Merah (Erythrina cristagali), 
Beringin (Ficus benjamina), Kersen (Muntingia calabura), Sengon (Albazia Falcataria), Pinus (Pinus merkusii), Kamboja (Plumeria rubra), Glodogan Tiang (Polyalthia longifolia), Jambu (Psidium guajava), Ki Hujan (Samanea saman), dan Kecrutan (Spathodea campanulata). Dengan skor 65\%, 70\%, 75\%, dan 80\%, sedangkan persentase dari keseluruhan jenis vegetasi yang sesuai sekitar 58,62\%. Vegetasi mayoritas yang ditanam pada kategori ini yaitu Bunga kupu-Kupu (Bauhinia blakeana), Sengon (Albazia Falcataria), dan Kesumba (Bixa Arborea). Sedangkan yang merupakan vegetasi minoritas yaitu Cemara Norflok (Araucaria heterophylla), Bintaro (Cerbera odollam), Kecrutan (Spathodea campanulata), dan Glodogan Tiang (Polyalthia longifolia). Penanaman vegetasi ini umumnya berada di RTH di area yang khusus untuk kawasan RTH dan RTH sepanjang jalan lingkungan.

Kemudian, jenis vegetasi yang termasuk kategori kurang baik yaitu vegetasi Palem Raja (Roystonea regia) dengan skor 60\%,sedangkan persentase dari keseluruhan jenis vegetasi yang sesuai sekitar 3,45\%. Penanaman berada di RTH Pocket Park (Taman Lingkungan) dan RTH ini tampak gersang dengan masuknya sinar radiasi yang berlebih. Sedangkan yang termasuk kategori buruk yaitu Palem Merah (Crytostachys renda) dengan skor 40\% dan persentase dari keseluruhan jenis vegetasi yang sesuai sekitar 3,45\%. Penanaman juga berada di RTH Pocket Park (Taman Lingkungan).

Berdasarkan penilaian dan hasil kategori jenis vegetasi, maka keragaman jenis vegetasi dalam fungsinya sebagai peneduh sudah memenuhi kriteria. Umumnya jenis vegetasi ini adalah pohon besar dengan memiliki ciri fisik yang tidak jauh berbeda dengan peredam kebisingan yaitu relatif tingg, bentuk tajuk spreading, bulat, dome, irregular, bermassa daun padat, berkanopi besar dan lebar, dan memilik daun tebal. Sedangkan jenis vegetasi yang belum memenuhi kriteria yaitu yang memiliki ciri fisik massa daun kurang padat, kurang tinggi, dan berkanopi sempit.

Penempatan vegetasi yang dirasa sesuai yaitu pada RTH berupa kavling kosong, RTH di area yang khusus untuk kawasan RTH, dan di RTH sepanjang jalan lingkungan berada di setiap jalan cluster BGH. Hal ini dikarenakan jenis 
vegetasi yang berada di RTH tersebut sudah memiliki kriteria fisik yang sesuai dengan fungsi peredam kebisingan. Terutama pada RTH sepanjang jalan lingkungan yang memang sengaja ditanam vegetasi peneduh untuk menghindari pengguna jalan dari sengatan sinar matahari. Lain halnya dengan vegetasi di RTH Pocket Park yang kriteria fisiknya belum memenuhi fungsi peneduh. RTH yang sudah memenuhi kebutuhan fungsinya dalam modifikasi suhu yaitu sekitar $190.944 \mathrm{~m}^{2}$ dan yang belum memenuhi sekitar $1.576 \mathrm{~m}^{2}$ (Gambar 21.) 


\section{Kontrol Kelembaban Udara}

Kelembaban udara merupakan salah satu faktor penting dalam meningkatkan kenyamanan thermal bagi manusia. Karena itu kelembaban udara perlu dikontrol agar penghuni Cluster BGH dapat menikmati kenyamanan jika tinggal dan menghuni rumah di kawasan ini (Tabel 17.).

Tabel 17. Kriteria Penilaian Aspek Fungsi Kontrol Kelembaban Udara

\begin{tabular}{|c|c|c|c|c|c|c|c|c|}
\hline \multirow{2}{*}{ No } & \multirow{2}{*}{ Nama Latin } & \multirow{2}{*}{ Nama Lokal } & \multicolumn{4}{|c|}{$\begin{array}{c}\text { Kriteria Fungsi } \\
\text { Kontrol RH }\end{array}$} & \multirow{2}{*}{$\begin{array}{c}\text { Skor } \\
(\%)\end{array}$} & \multirow{2}{*}{ Kategor } \\
\hline & & & k1 & k2 & k3 & k4 & & \\
\hline 1 & Acasia auriculiform & Akasia & 1 & 2 & 4 & 4 & 68,75 & BA \\
\hline 2 & Acasia mangium & Akasia Daun Lebar & 3 & 2 & 4 & 4 & 81,25 & SB \\
\hline 3 & Araucaria heterophylla & Cemara Norflok & 2 & 4 & 4 & 4 & 87,50 & SB \\
\hline 4 & Bauhinia blakeana & Bunga kupu-Kupu & 3 & 1 & 3 & 3 & 62,50 & BA \\
\hline 5 & Bixa Arborea & Kesumba & 2 & 2 & 1 & 3 & 50,00 & $\mathrm{~KB}$ \\
\hline 6 & Callistemon citrinus & Sikat Botol & 3 & 2 & 3 & 3 & 68,75 & BA \\
\hline 7 & Cerbera odollam & Bintaro & 2 & 1 & 2 & 4 & 56,25 & $\mathrm{~KB}$ \\
\hline 8 & Cocos nucifera & Kelapa & 4 & 4 & 2 & 3 & 81,25 & SB \\
\hline 9 & Crytostachys renda & Palem Merah & 4 & 3 & 1 & 3 & 68,75 & BA \\
\hline 10 & Dimocarpus longan & Kelengkeng & 1 & 3 & 4 & 4 & 75,00 & BA \\
\hline 11 & Elaeis quenensis & Kelapa Sawit & 4 & 3 & 2 & 3 & 75,00 & BA \\
\hline 12 & Erythrina cristagali & Dadap Merah & 3 & 2 & 3 & 3 & 68,75 & BA \\
\hline 13 & Ficus benjamina & Beringin & 1 & 2 & 4 & 4 & 68,75 & BA \\
\hline 14 & Ficus elastica & Beringin Karet & 2 & 1 & 1 & 4 & 50,00 & $\mathrm{~KB}$ \\
\hline 15 & Ficus lyrata & Biola Cantik & 1 & 2 & 4 & 3 & 62,50 & BA \\
\hline 16 & Gmelina sp. & Jati Putih & 2 & 2 & 2 & 4 & 62,50 & BA \\
\hline 17 & Mangifera indica & Mangga & 1 & 1 & 3 & 3 & 50,00 & $\mathrm{~KB}$ \\
\hline 18 & Muntingia calabura & kersen & 3 & 3 & 3 & 4 & 81,25 & SB \\
\hline 19 & Paraserianthes falcataria & Sengon & 3 & 2 & 2 & 4 & 68,75 & BA \\
\hline 20 & Pinus merkusii & Pinus & 3 & 4 & 4 & 4 & 93,75 & SB \\
\hline 21 & Plumeria rubra & Kamboja & 1 & 4 & 4 & 2 & 68,75 & $\mathrm{BA}$ \\
\hline 22 & Polyalthia longifolia & Glodogan Tiang & 1 & 1 & 1 & 4 & 43,75 & $\mathrm{~KB}$ \\
\hline 23 & Psidium guajava & Jambu & 3 & 4 & 1 & 3 & 68,75 & BA \\
\hline 24 & Pterocarpus indicus & Angsana & 1 & 2 & 3 & 4 & 62,50 & BA \\
\hline 25 & Roystonea regia & Palem Raja & 4 & 4 & 1 & 3 & 75,00 & BA \\
\hline
\end{tabular}


Tabel 17. Lanjutan

\begin{tabular}{lllllllll}
26 & Samanea saman & Ki Hujan & 2 & 2 & 4 & 4 & 75,00 & BA \\
\hline 27 & Spathodea campanulata & Kecrutan & 2 & 3 & 3 & 3 & 68,75 & BA \\
\hline 28 & Swietenia mahagoni & Mahoni & 1 & 2 & 3 & 4 & 62,50 & BA \\
\hline 29 & Tectona grandis & Jati & 3 & 3 & 1 & 4 & 68,75 & BA \\
\hline & Rata-Rata & & & & & 68,10 & BA \\
\hline
\end{tabular}

Ket: $\quad$ K1: Kerapatan daun rendah

$\mathrm{K} 2$ : Berdaun jarum/kasar

K3: Tekstur batang kasar

K4: Jumlah daun banyak
Pembobotan penilaian:
Nilai 4: Sangat Baik (SB)
Nilai 3: Baik (BA)
Nilai 2: kurang baik (KB)
bila $\geq 81 \%$ kriteria terpenuhi bila $61-80 \%$ kriteria terpenuhi
Nilai 1: Buruk (BU)
bila $41-60 \%$ kriteria terpenuhi
bila $\leq 40 \%$ kriteria terpenuhi

Dari hasil penilaian kriteria fisik vegetasi dan kriteria fungsi ekologis kontrol kelembaban udara, maka jenis vegetasi yang termasuk dalam kategori sangat baik dalam mengontrol kelembaban udara yaitu Akasia Daun Lebar (Acasia mangium), Cemara Norflok (Araucaria heterophylla), Kelapa (Cocos nucifera), Kersen (Muntingia calabura), dan Pinus (Pinus merkusii) dengan skor $81,25 \%, 87,50 \%$, 93,75 dan mempunyai persentase sekitar 17,24\% dari total keragaman vegetasi di cluster BGH. Jenis vegetasi tersebut merupakan vegetasi yang ditanam di RTH di area yang khusus untuk kawasan RTH.vegetasi yang memiliiki nilai ekologis dan umumnya memiliki daun bertekstur kasar atau berdaun jarum. Jenis vegetasi ini memiliki daun yang banyak, sehingga radiasi matahari sulit masuk ke dalam sela-sela tajuk dan akan meningkatkan kelembaban udara yang berlebih di bawah tajuk pohon.

Vegetasi yang memiliki kategori baik dalam mengontrol kelembaban udara yaitu vegetasi jenis Akasia (Acasia auriculiform), Bunga kupu-Kupu (Bauhinia blakeana), Sikat Botol (Callistemon citrinus), Palem Merah (Crytostachys renda), Kelengkeng (Dimocarpus longan), Kelapa Sawit (Elaeis guenensis), Dadap Merah (Erythrina cristagali), Beringin (Ficus benjamina), Biola Cantik (Ficus lyrata), Sengon (Paraserianthes falcataria), Kamboja (Plumeria rubra), Jambu (Psidium guajava), Angsana (Pterocarpus indicus), Palem Raja (Roystonea regia), Mahoni (Swietenia mahagoni), Ki Hujan 
(Samanea saman), Kecrutan (Spathodea campanulata), Jati (Tectona grandis), Jati Putih (Gmelina sp.), dan dengan skor 68,75\%, 62,50\%, 75\% dan persentase sekitar $65,52 \%$ dari total keragaman vegetasi di clusteri BGH. Umumnya vegetasi-vegetasi ini ditanam menyebar di RTH Pocket Park, RTH sepanjang jalan lingkungan dan RTH berupa kavling kosong.

Vegetasi yang memiliki kategori kurang baik yaitu jenis vegetasi Kesumba (Bixa Arborea), Bintaro (Cerbera odollam), Beringin Karet (Ficus elastica), Mangga (Mangifera indica), dan Glodogan Tiang (Polyalthia longifolia) dengan skor $50 \%, 56,25 \%$, dan $43,75 \%$ dan persentase sekitar $17,24 \%$ dari total keragaman vegetasi di clusteri BGH. Jenis vegetasi ini tidak terlau berpotensi dalam mengontrol kelembaban udara, tapi sebagian dari kriteria fisiknya dapat memenuhi kriteria fungsi ekologi ini (batang dan daun). Vegetasi-vegetasi ini biasa ditanam di RTH di area yang khusus untuk kawasan RTH dan RTH Pocket Park.

Berdasarkan penilaian dan hasil kategori jenis vegetasi, maka keragaman jenis vegetasi dalam fungsinya dalam kontrol kelembaban udara sudah memenuhi kriteria. Umumnya jenis vegetasi ini adalah pohon yang memiliki kerapatan daun rendah, berdaun jarum/kasar, bertekstur batang kasar dan jumlah daun banyak. Sedangkan jenis vegetasi yang kurang sesuai yaitu jenis vegetasi berdaun sedikit, batang dan daun tidak bertekstur.

Penempatan vegetasi yang dirasa sesuai yaitu pada RTH berupa kavling kosong, RTH sepanjang jalan lingkungan, dan RTH di area yang khusus untuk kawasan RTH. Hal ini dikarenakan jenis vegetasi yang berada di RTH tersebut sudah memiliki kriteria fisik yang sesuai dengan fungsi kontrol kelembaban udara. Lain halnya dengan vegetasi di RTH Pocket Park yang kriteria fisiknya belum memenuhi fungsi mengontrol kelembaban udara. Sehingga di RTH ini tampak gersang dan kering dan tidak ada intensitas penghuni cluster BGH melakukan aktivitas di RTH ini. RTH yang sudah memenuhi kebutuhan fungsinya dalam mengontrol kelembaban udara yaitu sekitar $173.072 \mathrm{~m}^{2}$ dan yang belum memenuhi fungsinya sekitar $19.448 \mathrm{~m}^{2}$ (Gambar 22.) 


\section{Penahan Angin}

Angin merupakan salah satu gejala alam yang dapat mempengaruhi kenyamanan seseorang. Angin dengan kecepatan yang kencang akan membuat manusia merasa tidak nyaman. Oleh karena itu diperlukan penilaian karakteristik fungsi ekologis penahan angin terhadap jenis vegetasi di Cluster BGH untuk mengetahui jenis vegetasi yang sesuai dalam menahan angin (Tabel 18.).

Tabel 18. Kriteria Penilaian Aspek Fungsi Penahan Angin

\begin{tabular}{|c|c|c|c|c|c|c|c|c|c|}
\hline \multirow{2}{*}{ No } & \multirow{2}{*}{ Nama Latin } & \multirow{2}{*}{ Nama Lokal } & \multicolumn{5}{|c|}{$\begin{array}{l}\text { Kriteria Fungsi } \\
\text { Penahan Angin }\end{array}$} & \multirow{2}{*}{$\begin{array}{l}\text { Skor } \\
(\%)\end{array}$} & \multirow{2}{*}{ Kategori } \\
\hline & & & K1 & K2 & K3 & K4 & K5 & & \\
\hline 1 & Acasia auriculiform & Akasia & 3 & 4 & 4 & 4 & 4 & 95 & SB \\
\hline 2 & Acasia mangium & Akasia Daun Lebar & 4 & 4 & 4 & 2 & 2 & 80 & BA \\
\hline 3 & Araucaria heterophylla & Cemara Norflok & 4 & 4 & 4 & 3 & 1 & 80 & $\mathrm{BA}$ \\
\hline 4 & Bauhinia blakeana & Bunga Kupu-Kupu & 4 & 2 & 3 & 3 & 2 & 70 & $\mathrm{BA}$ \\
\hline 5 & Bixa Arborea & Kesumba & 2 & 1 & 3 & 3 & 3 & 60 & KB \\
\hline 6 & Callistemon citrinus & Sikat Botol & 3 & 2 & 4 & 2 & 2 & 65 & BA \\
\hline 7 & Cerbera odollam & Bintaro & 4 & 2 & 3 & 3 & 3 & 75 & BA \\
\hline 8 & Cocos nucifera & Kelapa & 1 & 2 & 4 & 1 & 1 & 45 & $\mathrm{~KB}$ \\
\hline 9 & Crytostachys renda & Palem Merah & 4 & 2 & 3 & 2 & 1 & 60 & $\mathrm{~KB}$ \\
\hline 10 & Dimocarpus longan & Kelengkeng & 3 & 4 & 4 & 4 & 4 & 95 & SB \\
\hline 11 & Elaeis guenensis & Kelapa Sawit & 2 & 3 & 4 & 1 & 1 & 55 & $\mathrm{~KB}$ \\
\hline 12 & Erythrina cristagali & Dadap Merah & 3 & 2 & 2 & 3 & 2 & 55 & $\mathrm{~KB}$ \\
\hline 13 & Ficus benjamina & Beringin & 4 & 3 & 4 & 1 & 4 & 80 & $\mathrm{BA}$ \\
\hline 14 & Ficus elastica & Beringin Karet & 4 & 4 & 3 & 4 & 3 & 90 & SB \\
\hline 15 & Ficus lyrata & Biola Cantik & 3 & 3 & 4 & 2 & 4 & 80 & BA \\
\hline 16 & Gmelina sp. & Jati Putih & 3 & 4 & 4 & 4 & 3 & 90 & SB \\
\hline 17 & Mangifera indica & Mangga & 3 & 4 & 4 & 4 & 4 & 95 & SB \\
\hline 18 & Muntingia calabura & Kersen & 4 & 2 & 4 & 2 & 2 & 70 & BA \\
\hline 19 & Paraserianthes falcataria & Sengon & 4 & 4 & 1 & 4 & 2 & 75 & BA \\
\hline 20 & Pinus merkusii & Pinus & 4 & 4 & 4 & 2 & 2 & 80 & BA \\
\hline 21 & Plumeria rubra & Kamboja & 2 & 1 & 3 & 4 & 4 & 70 & BA \\
\hline 22 & Polyalthia longifolia & Glodogan Tiang & 3 & 3 & 3 & 4 & 4 & 85 & SB \\
\hline 23 & Psidium guajava & Jambu & 4 & 2 & 4 & 2 & 2 & 70 & BA \\
\hline 24 & Pterocarpus indicus & Angsana & 4 & 4 & 2 & 4 & 4 & 90 & SB \\
\hline 25 & Roystonea regia & Palem Raja & 4 & 3 & 3 & 1 & 1 & 60 & $\mathrm{~KB}$ \\
\hline 26 & Samanea saman & Ki Hujan & 1 & 4 & 1 & 1 & 2 & 45 & $\mathrm{~KB}$ \\
\hline
\end{tabular}


Tabel 18. Lanjutan

\begin{tabular}{|c|c|c|c|c|c|c|c|c|c|}
\hline 27 & Spathodea campanulata & Kecrutan & 3 & 3 & 3 & 3 & 3 & 75 & BA \\
\hline 28 & Swietenia mahagoni & Mahoni & 4 & 3 & 2 & 2 & 4 & 75 & BA \\
\hline 29 & Tectona grandis & Jati & 2 & 4 & 2 & 3 & 2 & 65 & BA \\
\hline \multicolumn{3}{|c|}{ Rata-Rata } & & & & & & 73,45 & BA \\
\hline Ket: & $\begin{array}{l}\text { K1: Dahan yan } \\
\text { K2: Vegetasi ti } \\
\text { K3: Daunnya t } \\
\text { K4: Tajuk mas } \\
\text { K5: Bermassa }\end{array}$ & $\begin{array}{l}\text { kuat tapi c } \\
\text { gi agar lu } \\
\text { k mudah } \\
\text { dan rindar } \\
\text { un rapat/b }\end{array}$ & ur & adu & igi lu & & & & \\
\hline \multicolumn{2}{|c|}{ Pembobotan penilaian: } & $\begin{array}{l}\text { Nilai 4: } \mathrm{S} \\
\text { Nilai 3: } \\
\text { Nilai 2: } \mathrm{k} \\
\text { Nilai 1: B }\end{array}$ & $\begin{array}{l}\text { aik ( } \\
\text { aik (I } \\
\text { U) }\end{array}$ & & $\begin{array}{l}\text { bila } \\
\text { bila } \\
\text { bila } \\
\text { bila }\end{array}$ & $\begin{array}{l}810 \\
1-80 \\
1-60 \\
40^{\circ}\end{array}$ & $\begin{array}{l}\mathrm{krit} \\
0 \mathrm{kr} \\
0 \mathrm{kr} \\
\mathrm{krit}\end{array}$ & $\begin{array}{l}\text { cia ter } \\
\text { eria te } \\
\text { eria te } \\
\text { cia ter }\end{array}$ & $\begin{array}{l}\text { nuhi } \\
\text { enuhi } \\
\text { enuhi } \\
\text { nuhi }\end{array}$ \\
\hline
\end{tabular}

Setelah dilakukan penilaian, maka kesimpulannya yaitu jenis vegetasi yang memiliki kategori sangat baik dalam menahan angin yaitu vegetasi Akasia (Acasia auriculiform), Kelengkeng (Dimocarpus longan), Beringin Karet (Ficus elastica), Jati Putih (Gmelina sp.), Mangga (Mangifera indica), Glodogan Tiang (Polyalthia longifolia), dan Angsana (Pterocarpus indicus) dengan skor 95\%, $90 \%$, 85\%, dan persentase vegetasi dari total keragamannya sekitar 24,14\%. Umumnya jenis vegetasi ini ditanam di RTH berupa kavling kosong dan RTH di area yang khusus untuk kawasan RTH. Vegetasi dominannya yaitu Akasia (Acasia auriculiform) dan Jati Puth (Gmelina sp.), sedangkan vegetasi minoritasnya yaitu Kelengkeng (Dimocarpus longan) dan Glodogan Tiang (Polyalthia longifolia). Sebagian jenis vegetasi ini adalah pohon besar, dimana pohon besar dan ditanam berderet mampu mengurangi kecepatan angin sekitar 40$50 \%$. Vegetasi kategori ini cukup untuk menahan, menyerap, dan mengalirkan tiupan angin sehingga dapat menimbulkan iklim mikro.

Jenis vegetasi yang termasuk kategori baik dalam menahan angin yaitu Akasia Daun Lebar (Acasia mangium), Cemara Norflok (Araucaria heterophylla), Bunga Kupu-Kupu (Bauhinia blakeana), Sikat Botol (Callistemon citrinus), Bintaro (Cerbera odollam), Beringin (Ficus benjamina), Biola Cantik (Ficus lyrata), Kersen (Muntingia calabura), Sengon (Paraserianthes falcataria), Pinus (Pinus merkusii), Kamboja (Plumeria rubra), Jambu (Psidium guajava), Kecrutan 
(Spathodea campanulata), Mahoni (Swietenia mahagoni), Jati (Tectona grandis), dengan skor $65 \%, 70 \%, 75 \%, 80 \%$, dan persentase jenis vegetasinya dari total keragaman vegetasi sekitar 51,72\%. Vegetasi kategori ini umumnya ditanam di RTH sepanjang jalan lingkungan dan RTH di area yang khusus untuk kawasan RTH. Vegetasi dominannya yaitu jenis Biola Cantik (Ficus lyrata), Mahoni (Swietenia mahagoni), dan Jati (Tectona grandis). Sedangkan yang termasuk vegetasi minoritas yaitu Cemara Norflok (Araucaria heterophylla), Bintaro (Cerbera odollam), dan Kecrutan (Spathodea campanulata). Vegetasi kategori ini cukup untuk menahan, menyerap, dan mengalirkan tiupan angin sehingga dapat menimbulkan iklim mikro sama halnya dengan kategori sangat baik.

Kemudian yang termasuk dalam kategori kurang baik yaitu jenis vegetasi Kesumba (Bixa Arborea), Kelapa (Cocos nucifera), Palem Merah (Crytostachys renda), Kelapa Sawit (Elaeis guenensis), Dadap Merah (Erythrina cristagali), Palem Raja (Roystonea regia), Ki Hujan (Samanea saman) dengan skor 45\%, $55 \%, 60 \%$, dan persentase keseluruhan vegetasi yang sesuai sekitar $24,14 \%$. Jenis vegetasi ini umumnya ditanam di RTH sepanjang jalan lingkungan dan di RTH Pocket Park. Jenis vegetasi yang dominan yaitu Kesumba (Bixa Arborea), Ki Hujan (Samanea saman),dan jenis vegetasi minoritas yaitu Kelapa Sawit (Elaeis guenensis) dan Palem Raja (Roystonea regia).

Dari hasil penilaian dan kategori setiap jenis vegetasinya, maka dapat dievaluasi bahwa keragaman vegetasi sudah memenuhi kriteria dalam menahan angin. Hal ini dikarenakan banyaknya jenis vegetasi yang sudah memenuhi kriteria fisik dalam menahan angin. Umumnya jenis vegetasi ini memiliki ciri fisik dahan yang kuat tapi cukup lentur, vegetasi tinggi agar luas area yg terlindungi luas, daunnya tidak mudah gugur, tajuk masif dan rindang, bermassa daun rapat/berdaun tebal. Sedangkan jenis vegetasi yang kurang sesuai memiliki ciri fisik vegetasi kering, daun mudah gugur, dan bermassa daun kurang padat.

Penempatan vegetasi yang dirasa sesuai yaitu pada RTH berupa kavling kosong, RTH di area yang khusus untuk kawasan RTH, dan di RTH sepanjang jalan lingkungan berada di setiap jalan cluster BGH. Hal ini dikarenakan jenis vegetasi yang berada di RTH tersebut sudah memiliki kriteria fisik yang sesuai 
dengan fungsi penahan angin. Terutama pada RTH di area yang khusus untuk kawasan RTH yang memang sengaja ditanam untuk memberikan kenyamanan dari udara yang bergerak bagi penghuni di dalam maupun luar rumah. Lain halnya dengan vegetasi di RTH Pocket Park yang kriteria fisiknya belum memenuhi fungsi penahan angin. Sehingga tampak di RTH tersebut berangin dan gersang. RTH yang sudah memenuhi kebutuhan fungsinya dalam menahan angin yaitu sekitar $164.248 \mathrm{~m}^{2}$ dan yang belum memenuhi fungsinya sekitar $28.272 \mathrm{~m}^{2}$ (Gambar 23.). 


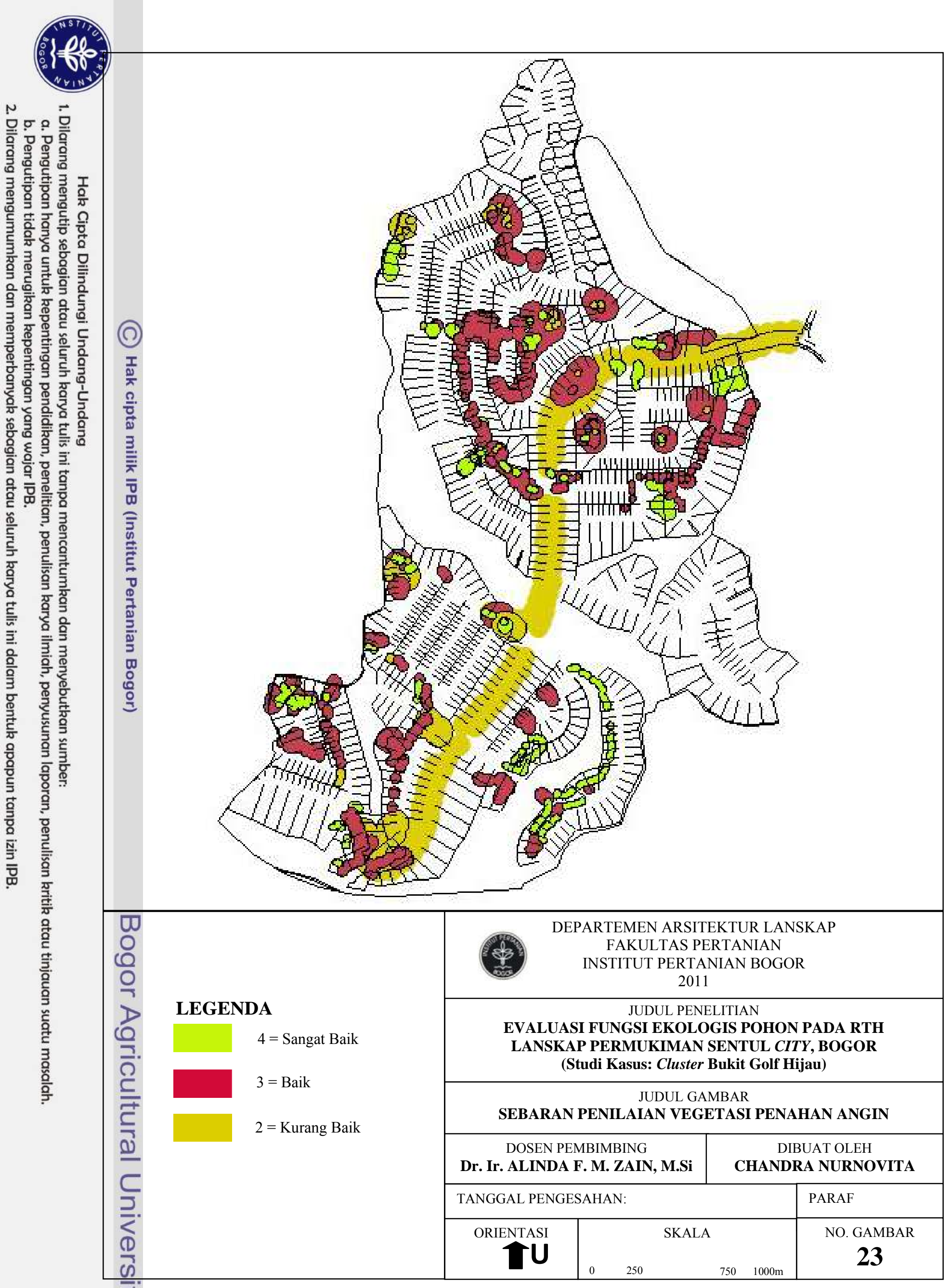




\section{REKOMENDASI}

Dari hasil analisis dan evaluasi berdasarkan penilaian, maka telah disimpulkan bahwa keragaman vegetasi di cluster BGH memiliki fungsi ekologis yang berbeda-beda berdasarkan keragaman kriteria fisik masing-masing. Oleh karena itu diperlukan suatu rekomendasi agar fungsi ekologis tersebut dapat berfungsi secara maksimal. Dalam mengoptimalkan fungsi RTH diperlukan suatu rekomendasi bagi Rencana Pengelolaan Lingkungan (RKL) Sentul City di masa yang akan datang antara lain:

\section{Peredam Kebisingan}

Telah diketahui bahwa vegetasi yang memiliki kategori sangat baik pada kriteria fungsi ekologi ini hanya sekitar 24,14\%, kategori baik sekitar 41,38\%, dan kategori kurang baik sekitar 34,48\%. Hal ini menandakan bahwa tidak ada jenis vegeteasi yang kriteria fisiknya tidak sesuai dengan kriteria fungsi ekologis peredam kebisingan, semuanya memiliki kemampuan dalam meredam pada bagian masing-masing ciri fisik vegetasi. Untuk itu dilakukan rekomendasi dalam desain maupun penanaman yang baik dalam menciptakan fungsi maksimal kriteria ini.

- Kategori Sangat Baik

Jenis vegetasi yang termasuk kategori ini baik untuk dipertahankan guna memaksimalkan fungsi vegetasi dalam meredam kebisingan. Karena secara fisik vegetasi jenis ini sudah sesuai dengan fungsinya, terutama penanamannya di kawasan permukiman guna menghindari bising dari kendaraan bermotor maupun pekerjaan bangunan atau kavling.

\section{- Kategori Baik}

Jenis vegetasi ini umumnya memiliki beberapa ciri fisik yang sudah sesuai dengan fungsi ekologis ini. Untuk memaksimalkan fungsinya maka jenis vegetasi ini baik untuk dipertahankan dan dapat dilakukan tambahan penanaman untuk jenis semak (Laurie, 1986), karena pohon dan semak memiliki daya serap yang tinggi terhadap kebisingan. Selain itu juga dapat dilakukan penanaman beberapa spesies (Carpenter et al, 1975). Karena penanaman satu spesies hanya dapat menangkap suara dengan frekuensi rendah 
atau tinggi saja, tapi tidak efektif dalam mereduksi suara dengan fekuensi sedang (antara tinggi dan rendah).

- Kategori Kurang Baik

Untuk memaksimalkan penggunaan jenis vegetasi ini tanpa melakukan penebangan dapat dilakukan penanaman yang terdiri dari beberapa lapis vegetasi atau terdapat kombinasi pohon, perdu, semak (DPU Dirjen Bina Marga, 1996) terutama pada jenis vegetasi sepanjang jalan lingkungan (Gambar 24.).

Penanaman vegetasi yang sesuai dengan kriterianya dari hasil evaluasi meliputi tajuk rapat dan massa daun rapat, berdaun tebal, cabang dan batang besar, mempunyai tangkai-tangkai daun, daun rindang dan ringan. Dengan vegetasi yang termasuk kategori sangat baik seperti Beringin (Ficus benjamina), Jati Putih (Gmelina arborea), Akasia (Acacia auriculiform), Angsana (Pterocarpus indicus), Beringin Karet (Ficus elastica), Biola Cantik (Ficus lyrata), Mangga (Mangifera indica). Semak dan perdu yang digunakan dapat bermacam-macam jenis.

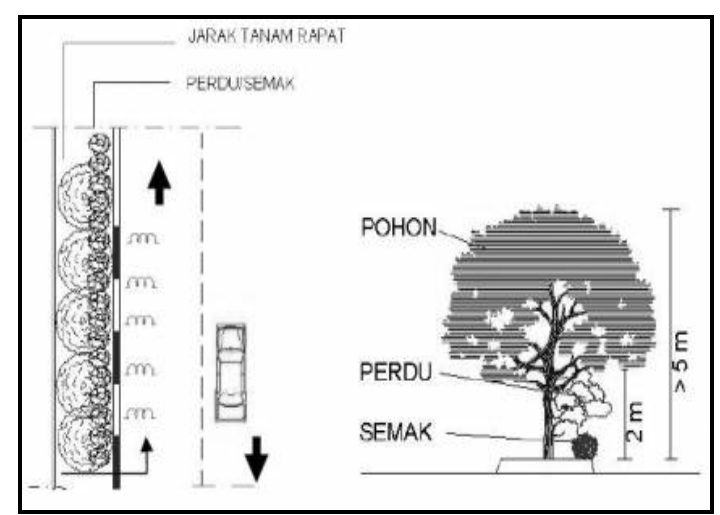

Gambar 24. Desain Peredam Kebisingan Jalan

(Sumber: DPU Dirjen Bina Marga, 1996)

\section{Modifikasi Suhu (Peneduh)}

Telah diketahui bahwa vegetasi yang memiliki kategori sangat baik pada kriteria fungsi ekologi ini sekitar 34,48\%, kategori baik sekitar 58,62\%, kategori kurang baik sekitar 3,45\%, dan kategori buruk 3,45\%. 
- Kategori Sangat Baik

Dalam kategori ini jenis vegetasi yang sudah sesuai sudah cukup banyak dari semua keragaman vegetasi yang ada di cluster BGH. Umumnya vegetasi ini ditanam di RTH berupa kavling kosong dan RTH di area yang khusus untuk kawasan RTH. Jenis vegetasi ini sangat diharapkan untuk dipertahankan, terutama vegetasi yang berada di RTH area yang khusus untuk kawasan RTH, karena RTH berupa kavling kosong sewaktu-waktu akan dirubah dan dibangun rumah, sehingga vegetasi di RTH itu akan ditebang dan kemungkinan suhu di cluster akan berubah sedikit meningkat.

- Kategori Baik

Jenis vegetasi dari kategori ini umumnya ditanam di RTH di area yang khusus untuk kawasan RTH dan RTH sepanjang jalan lingkungan. Untuk di RTH area yang khusus untuk kawasan RTH vegetasinya perlu dipertahankan keberadaannya, sedangkan pada RTH sepanjang jalan lingkungan, terutama jenis vegetasi Ki Hujan (Samanea saman) lebih diperhatikan keberadaan akar di bawah tanah yang sewaktu-waktu menghalangi jaringan usilitas bawah tanah karena Perakarannya yang sangat meluas. Oleh karena itu perlu dilakukan pemeliharaan rutin dengan memotong akar pohon secara berkala terutama pada vegetasi yang berusia tua.

- Kategori Kurang Baik

Dalam kategori ini, vegetasinya terutama berada di RTH Pocket Park (Taman Lingkungan). Karena fungsinya hanya sebagai estetika di RTH tersebut, maka diperlukan jenis vegetasi peneduh untuk dikombinasikan agar RTH tersebut tidak terlalu panas terkena sinar matahri sehingga RTH tidak terlalu silau untuk dipandang, umumnya memiliki ketinggian minimal $2 \mathrm{~m}$ (DPU Dirjen Bina Marga, 1996). Selain itu perlu dikombinasikan dengan hard elemen seperti batu dan elemen air untuk mengurangi silaunya matahari agar dapat dipantulkan kembali. Dengan adanya kombinasi vegetasi yang relatif tinggi dengan tajuk yang saling bersinggungan, maka penggunaan pohon peneduh tidak menghalangi datangnya sinar matahari ke dalam kawasan tersebut (Gambar 25.). Penanaman vegetasi baru dengan tajuk yang rapat (Griffiths, 1971) dikombinasikan dengan hard elemen atau elemen air. 


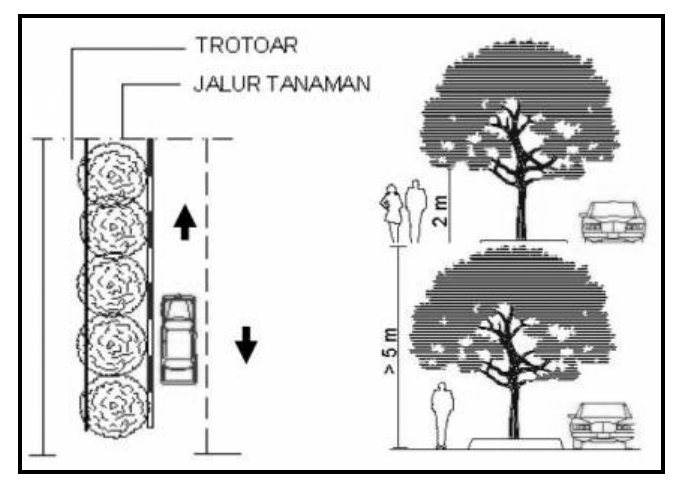

Gambar 25. Desain Peneduh Jalan (Sumber: DPU Dirjen Bina Marga, 1996)

- Kategori Buruk

Jenis vegetasi ini sama seperti halnya pada kategori kurang baik hanya ditanam di RTH Pocket Park (Taman Lingkungan). Oleh karena itu diperlukan penanaman vegetasi baru dimana dapat mempengaruhi fungsi peneduh terutama di RTH pocket park. Selain itu untuk menurunkan suhu agar tidak terlalu tinggi dapat ditambahkan elemen air atau badan air dari RTH tersebut. badan air (kolam atau danau) dapat direncanakan pada area dimana mendapat penyinaran radiasi sinar matahari yang tertinggi, panas matahari yang sedang terik-teriknya akan diserap oleh badan air, sehingga suhu disekitarnya akan turun dan membuat suhu dirasakan lebih sejuk. Penanaman vegetasi yang sesuai dengan kriterianya dari hasil evaluasi meliputi pohon relatif tinggi, bentuk tajuk spreading, bulat, dome, irregular, bermassa daun padat, berkanopi besar dan lebar, daun tebal. Dengan vegetasi yang termasuk kategori sangat baik seperti Akasia (Acacia auriculiform), Bintaro (Cerbera odollam), Kelengkeng (Dimocarpus longan), Beringin Karet (Ficus elastica), Biola Cantik (Ficus lyrata), Jati Putih (Gmelina sp.), Mangga (Mangifera indica), Angsana (Pterocarpus indicus), Mahoni (Swietenia mahagoni), dan Jati (Tectona grandis).

\section{Kontrol Kelembaban Udara}

Telah diketahui bahwa vegetasi yang memiliki kategori sangat baik pada kriteria fungsi ekologi ini sekitar 17,24\%, kategori baik sekitar 65,52\%, kategori kurang baik sekitar 17,24\%. 
- Kategori Sangat Baik

Dalam kategori ini jenis vegetasi yang sudah sesuai sudah cukup banyak dari semua keragaman vegetasi yang ada di cluster BGH. Umumnya vegetasi ini ditanam di RTH berupa kavling kosong dan RTH di area yang khusus untuk kawasan RTH. Jenis vegetasi ini sangat diharapkan untuk dipertahankan, terutama vegetasi yang berada di RTH area yang khusus untuk kawasan RTH, karena RTH berupa kavling kosong sewaktu-waktu akan dirubah dan dibangun rumah, sehingga vegetasi di RTH itu akan ditebang dan kemungkinan suhu di cluster akan berubah sedikit meningkat dan memerlukan kelembaban udara yang tinggi. Untuk mengurangi kelembaban yang tinggi agar tanah dapat subur kembali dengan baik, maka diperlukan penanaman pohon dengan perbedaan tinggi (strata). Karena dengan adanya perbedaan tinggi vegetasi dalam suatu kumpulan vegetasi dengan sistem lajur ditambah dengan adanya angin dapat menurunkan kelembaban udara di tiap lapisan tajuk vegetasi pohon tersebut.

- Kategori Baik

Sama halnya dengan kategori sangat baik, perlu dipertahankan keberadaan jenis vegetasi yang mampu dalam mengontrol kelembaban udara. Karena udara di bawah kanopi vegetasi juga lebih lembab daripada udara diatas permukaan tanpa naungan dan akibatnya lebih panas dibutuhkan untuk menaikkan suhu udara dibawah vegetasi.

- Kategori Kurang Baik

Dilakukan modifikasi dengan penanaman pohon-pohon dengan kerapatan cukup, dan dengan penanaman yang tajuknya bersinggungan. Vegetasi yang memiliki kerapatan daun rendah. Karena Kelembaban yang mendekati angka kenyamanan terdapat pada bagian pohon dengan kerapatan daun yang rendah (Bianpoen et al., 1989). Penanaman vegetasi yang sesuai dengan kriterianya dari hasil evaluasi meliputi kerapatan daun rendah, berdaun jarum atau kasar, tekstur batang kasar, jumlah daun banyak. Dengan vegetasi yang termasuk kategori sangat baik seperti Akasia Daun Lebar (Acasia mangium), Cemara Norflok (Araucaria heterophylla), Kelapa (Cocos nucifera), Kersen (Muntingia calabura), dan Pinus (Pinus merkusii). 


\section{Penahan Angin}

Telah diketahui bahwa vegetasi yang memiliki kategori sangat baik pada kriteria fungsi ekologi ini sekitar 24,14\%, kategori baik sekitar 51,72\%, dan kategori kurang baik sekitar $24,14 \%$

- Kategori Sangat Baik

Umumnya vegetasi ini ditanam di RTH berupa kavling kosong dan RTH di area yang khusus untuk kawasan RTH. Jenis vegetasi ini sangat diharapkan untuk dipertahankan, terutama vegetasi yang berada di RTH area yang khusus untuk kawasan RTH, karena RTH berupa kavling kosong sewaktu-waktu akan dirubah dan dibangun rumah, sehingga vegetasi di RTH itu akan ditebang. Berkurangnya vegetasi dapat menghalangi kecepatan angin mengarah ke rumah penghuni.

- Kategori Baik

Umumnya berada di RTH sepanjang jalan lingkungan dan RTH di area yang khusus untuk kawasan RTH. Diharapkan juga jenis vegetasi dari kategori ini dipertahankan terutama vegetasi yang ditanam di RTH sepanjang jalan lingkungan. Karena vegetasi ini dapat menghalangi alur angin yang mengarah ke rumah penghuni melalui arah jalan raya yang dapat membawa partikelpartikel debu atau polutan kendaraan bersamaan dengan angin.

- Kategori Kurang Baik

Jenis vegetasi ini ditanam di RTH sepanjang jalan lingkungan dan di RTH Pocket Park. Bagi vegetasi yang ditanam di RTH Pocket Park dapat dilakukan modifikasi dengan penanaman penanaman pohon-pohon rendah atau komposisi vegetasi yang berbeda ketinggian untuk menghalangi kencangnya angin yang masuk (Carpenter et al., 1975). Sehingga Pocket Park berada pada kondisi nyaman dengan adanya kombinasi antara jenis vegetasi yang berbeda. Jenis vegetasi ini ditanam di RTH Pocket Park. Sama halnya dengan vegetasi kategori kurang baik, jenis vegetasi ini perlu dilakukan modifikasi dengan penanaman penambahan pohon-pohon baru yang memiliki fungsi sebagai penahan angin terutama pohon-pohon tinggi. Karena dengan banyak tegakan pohon akan memanipulasi kecepatan turbulensi angin dengan cara 
menghalangi, membelokkan arah dan atau menyaringnya (Robinette,1983) (Gambar 26).

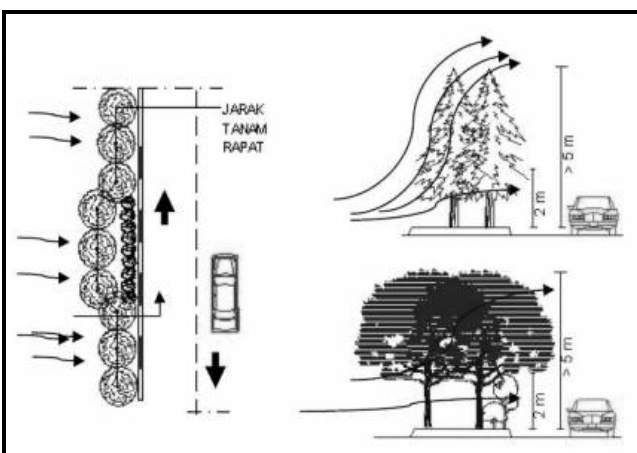

Gambar 26. Penanaman Pohon Evergreen dan Deciduous (Sumber: Russ, Thomas H, 2002)

Selain itu penanaman dengan komposisi vegetasi yang berbeda ketinggian mampu mengurangi kecepatan angin sekitar 40-50\% (carpenter et al., 1975). Penanaman vegetasi yang sesuai dengan kriterianya yaitu dahan yang kuat tapi cukup lentur, vegetasi tinggi, daunn yang tidak mudah gugur (evergreen), tajuk masif dan rindang, bermassa daun rapat atau berdaun tebal. Dengan vegetasi yang termasuk kategori sangat baik seperti vegetasi Akasia (Acasia auriculiform), Kelengkeng (Dimocarpus longan), Beringin Karet (Ficus elastica), Jati Putih (Gmelina sp.), Mangga (Mangifera indica), Glodogan Tiang (Polyalthia longifolia), dan Angsana (Pterocarpus indicus). 


\section{KESIMPULAN DAN SARAN}

\section{KESIMPULAN}

Berdasarkan tujuan dan hasil penelitian, maka dapat disimpulkan:

1. Dari hasil identifikasi diketahui vegetasi yang ada di Sentul City beraneka ragam sehingga menambah keindahan Sentul City, Bogor. Tetapi penanaman vegetasi di cluster Bukit Golf Hijau mayoritas memiliki fungsi ekologis yang lebih banyak. Selain itu tidak adanya aktivitas manusia dan kurang dikembangkan dalam pemanfaatan untuk kegiatan penghuni atau kegiatan sosial di RTH cluster Bukit Golf Hijau, sehingga fungsi RTH disini sangat optimal hanya untuk meningkatkan kualitas lingkungan bukan sebagai area untuk kegiatan manusia

2. Dari hasil analisis diketahui keberadaan vegetasi dalam mereduksi kebisingan belum mempengaruhi, karena baku mutu di cluster Bukit Golf Hijau masih di atas ambang baku mutu dari hasil literatur. Keberadaan vegetasi dalam modifikasi suhu cukup mempengaruhi, karena suhu di cluster Bukit Golf Hijau masih berada dalam suhu yang nyaman bagi penghuni atau berada di antara suhu kenyamanan hasil literatur. Keberadaan vegetasi dalam kontrol kelembaban udara belum mempengaruhi, karena RH di cluster Bukit Golf Hijau masih di atas RH kenyamanan bagi penghuni berdasarkan hasil literatur. Keberadaan vegetasi dalam penahan angin cukup mempengaruhi, karena kecepatan angin di cluster Bukit Golf Hijau berada pada skala 1 menurut skala beaufort dengan kecepatan teduh.

3. Dari hasil penilaian diketahui luasan RTH yang sudah memenuhi fungsi ekologi peredam kebisingan yaitu sekitar $177.953 \mathrm{~m}^{2}$, fungsi ekologis modifikasi suhu (peneduh) sekitar $190.944 \mathrm{~m}^{2}$, fungsi ekologis pengontrol kelembaban udara sekitar $173.072 \mathrm{~m}^{2}$, dan untuk fungsi ekologis penahan angin sekitar $164.248 \mathrm{~m}^{2}$. Dan dari hasil penilaian diketahui vegetasi yang berada di RTH berupa kavling kosong, RTH di area yang khusus untuk kawasan RTH, dan di RTH sepanjang jalan lingkungan sudah memenuhi kriterianya dalam memenuhi fungsi ekologis yaitu peredam kebisingan, modifikasi suhu (peneduh), pengontrol kelembaban udara, dan penahan 
angin. Sedangkan vegetasi yang berada di RTH pocket park belum memenuhi kriteria setiap fungsi ekologisnya karena tujuan utamanya yaitu untuk meningkatkan estetika lingkungan

4. Dari hasil penilaian dan evaluasi maka diberikan suatu rekomendasi guna untuk memperbaiki kualitas lingkungan di cluster Bukit Golf Hijau dalam memberikan kenyamanan bagi penghuni.

\section{SARAN}

Berdasarkan hasil penelitian yang telah dilaksanakan maka saran-saran yang dapat disampaikan adalah sebagai berikut :

1. Diharapkan dengan adanya penelitian ini bisa membuka pandangan betapa pentingnya keberadaan RTH terutama di lanskap permukiman untuk keberlangsungan hidup penghuninya dan memberikan pengaruh kepada pengembangan Sentul City dalam penyusunan Rencana Pengelolaan Lingkungan (RKL) Sentul City di masa yang akan datang datang.

2. Untuk pengembang Sentul City diharapkan tetap mempertahankan jumlah RTH yang luas di cluster Bukit Golf Hijau. Karena semakin banyak penghuni dan hunian maka RTH semakin sedikit dengan adanya pembangunan kavling sehingga jenis vegetasi yang ada di cluster Bukit Golf Hijau berkurang.

3. Untuk pengeola lebih memperhatikan penanaman vegetasi di RTH untuk fungsi ekologisnya. Fungsi peredam kebisingan, modifikasi suhu (peneduh), pengontrol kelembaban udara, dan penahan angin. Karena pada dasarnya manusia memerlukan kenyamanan ideal dari lingkungan huniannya. 


\section{DAFTAR PUSTAKA}

Bianpoen et al., (1989), Fungsi Taman dalam Kota (naskah laporan), Pusat Penelitian Teknologi dan Pemukiman Universitas Tarumanegara, Jakarta.

Booth, N.K. 1983. Basic Elements of Landscape Architecture Design. Waveland Press inc, Illnois.

Booth, N.K dan Hiss, E.J. 2005. Residential Landscape Architecture : Design Process for The Private Residence. Pearson prentice hall: New Jersey.

Bradley, C dan Millward, A. 1984. Successful Green Space: Do We Know It When We See It?. The Planner, July.

Budihardjo, E. (1997). Arsitektur dan kota di Indonesia. Bandung: Alumni.

Bukit Sentul Tbk. 2009. AMDAL Pembangunan Permukiman Bukit Sentul. Bandung: [penerbit tidak diketahui].

Carpenter PL, Walker TD dan Lanphear FO. 1975. Plants in The Landscape. San Fransisco : W.H. Freeman and Company.

Chiara, J.D. dan L.E. Koppelman. 1978. Standar Perencanaan Tapak (terjemahan). Jakarta : Erlangga.

Dahlan, E.N. 1992. Membangun Kota Kebun (Garden City) Bernuansa Hutan Kota. IPB Press dan Sekolah Pascasarjana IPB. Bogor.

Departemen Dalam Negeri. 2007. Peraturan Menteri Dalam Negeri No. 1 Tahun 2007 Tentang: Penataan Ruang Terbuka Hijau Kawasan Perkotaan. Jakarta.

Departemen Ketenaga Kerjaan. 1999. Keputusan Menteri Ketenaga Kerjaan Nomor 51 Tahun 1999: Jakarta.

Departemen Lingkungan Hidup. 1996. Keputusan Menteri Lingkungan Hidup Nomor 48 Tahun 1996: Jakarta.

Departemen Kesehatan. 1999. Keputusan Menteri Kesehatan Nomor 829/Menkes/SK/VII/1999: Jakarta.

Dewan Perwakilan Rakyat Republik Indonesia. 1992. Undang-Undang Republilk Indonesia Nomor 04 Tahun 1992 tentang Penataan Ruang.

Dewan Perwakilan Rakyat Republik Indonesia. 2007. Undang-Undang Republilk Indonesia Nomor 26 Tahun 2007 tentang Penataan Ruang. Jakarta. 
Direktorat Jenderal Bina Marga. 1996. Tata Cara Perencanaan Teknik Lanskap Jalan. Departemen Pekerjaan Umum. Jakarta: Direktorat Jenderal Bina Marga.

Eckbo, G. 1964. Urban landscape Design. New York : Mc Graw - Hill Book Co.

Echols, J.M. dan Shadily, H. 1996. An English-Indonesian Dictionary. Cornell University Press Ithaca and London.

Eliza, S. 1997. Evaluasi Karakter Taman Kantor. Jurusan Budidaya Pertanian. Institut Pertanian Bogor.

Gold, S.M. 1980. Recreation Planning and Design. Mcgraw-hill. New York.

Grey, G.W dan F.J. Deneke. 1978. Urban Forestry. New York: John Willey and Sons inc.

Griffiths, J. F. 1971. Climate and the Environment : the Atmosphere impact on man. Paul Elek, London.

Hakim, R. dan H. Utomo. 2004. Komponen Perancangan Arsitektur Lansekap: Prinsip-Unsur dan Aplikasi. Bumi Aksara, Jakarta.

Hidayat, I. 2008. Evaluasi Jalur Hijau Jalan Sebagai Penyangga Lingkungan Sekitarnya dan Keselamatan Pengguna Jalan Bebas Hambatan Jagorawi [Thesis]. Bogor: Sekolah Pascasarjana, Institut Pertanian Bogor.

Laurie, M. 1986. An Introduction to Landscape Architecture. New York: American Elsevier Publ. Co. Inc.

Margaretha, P. 2007. Studi Hubungan Antara kondisi Iklim Mikro dan Persepsi Pengunjung Terhadap Kenyamanan Termal [skripsi]. Bogor: Fakultas Pertanian, Institut Pertanian Bogor.

Nowak. DJ dan McPherson EG. 1997. Quantifying The Impact of Trees : The Chicago Urban Forest Climate Project. Journal Food Industries [serial online].

Nurisjah, S. dan Q. Pramukanto. 1995. Penuntun Praktikum perencanaan Lanskap. Diktat Jurusan Budidaya Pertanian. Fakultas Pertanian. Institut Pertanian Bogor.

Odum, E. P. 1993. Dasar-Dasar Ekologi. Yogyakarta: Gajah Mada University Press.

Prahasta, E. 2004. Sistem Informasi Geografis : Tutorial ArcView. CV. Informatika. Bandung. 
Rahmi, F. 2008. Perancangan dan Pelaksanaan Lanskap Cluster Permukiman Argenia, Sentul City, Bogor,Jawa Barat [Skripsi]. Bogor: Fakultas Pertanian, Institut Pertanian Bogor.

Rahmi, DH. 2002. Penyediaan Ruang Terbuka Hijau di Lingkungan Perumahan di yogyakarta dalam makalah Manusia dan Lingkungan Vol.IX No.3, November 2002. Pusat Studi Lingkungan Hidup Universitas Gajah Mada. Hal $101-114$.

Resosoedarmo SK Kartawinata, A Soegiarto. 1992. Pengantar Ekologi. Bandung: Rosdakarya.

Robinette, G. O. 1983. Landscape Planning for Energy Conservation. New York: Van Nostrad Reinhold Company.

Russ, H. 2002. Site Planning and Design handbook. New York: Mc Graw - Hill Book Co.

Simonds, J.O. 1983. Landscape Architecture. New York: Mc Graw - Hill Book Co.

Setyaningrum N. 2001. Pengelolaan Lanskap Danau dan Koridor Ditinjau dari Aspek Ekologis di Pemukiman Bukit Sentul, Jawa Barat [Skripsi]. Bogor: Fakultas Pertanian, Institut Pertanian Bogor.

Sukawi. http://senthong.wordpress.com/2009/09/02/kuantitas-dan-kualitas-ruangterbuka-hijau-rth-di-permukiman-kota/.1juni2010-07-02.

Thompson, J. William dan Sorvig, Kim. 2008. Sustainable Landscape Construction: A Guide to Green Building Outdoors. Washington DC: ISLAND PRESS.

Widagdo, S. 1998. Studi Tentang Reduksi kebisingan Menggunakan Vegetasi dan Kualitas Visual Lanskap Jalan Tol jagorawi. Program Pasca Sarjana. Institut Pertanian Bogor. Bogor.

Wikipedia. 2010. Kota Satelit. http://id.wikipedia.org/wiki/Kota_satelit. 5.13 Pm. 23 feb2010.[23 Februari 2010].

YAI dan BAPPEDA DKI. 2001.Penyusunan Strategi dan Program Penghijauan. Jakarta. 


\section{LAMPIRAN}

Lampiran 1. Identifikasi Vegetasi di RTH Cluster BGH (Sumber: Amdal 2009)

\begin{tabular}{|c|c|c|c|}
\hline No. & Nama Tanaman & Nama Latin & Jumlah \\
\hline 1 & Beringin & Ficus benjamina & 2 \\
\hline 2 & Beringin Karet & Ficus elastica & 19 \\
\hline 3 & Bintaro & Cerbera Odollan & 13 \\
\hline 4 & Biola Cantik & Ficus lyrata & 345 \\
\hline 5 & Bismarkia & Bismarckia sp. & 6 \\
\hline 6 & Bunga Kupu-kupu & Bauhinia blakeana & 241 \\
\hline 7 & Palm Ekor Tupai & Ukaria lagopo dioides & 17 \\
\hline 8 & Cassia Fistula & Cassia Fistula & 20 \\
\hline 9 & Dadap Merah & Erythrina cristagali & 27 \\
\hline 10 & Flamboyan & Delonix regia & 6 \\
\hline 11 & Gamelina & Gmelina sp. & 2 \\
\hline 12 & Glodokan Tiang & Polyalthia longifolia & 4 \\
\hline 13 & Jeunjing & Albazzia falcata & 3 \\
\hline 14 & Kamboja & Plumeria rubra & 8 \\
\hline 15 & Kecapi & Sandoricum koetjapie & 13 \\
\hline 16 & Kelapa Gading & Cocos nucifera & 7 \\
\hline 17 & Kelapa Sawit & Elaeis quenensis & 6 \\
\hline 18 & Lamtoro & Leucaena glauca & 33 \\
\hline 19 & Mahoni & Swietenia mahagoni & 341 \\
\hline 20 & Mengkudu & Morinda citrifolia & 1 \\
\hline 21 & Palm Botol & Mascarena sp. & 3 \\
\hline 22 & Palm Kuning & $\begin{array}{l}\text { Chrysalidocarpus } \\
\text { lutescens }\end{array}$ & 14 \\
\hline 23 & Palm Merah & Crytostachys lakka & 8 \\
\hline 24 & Palm Putri & Vitsia merlii & 30 \\
\hline 25 & Palm Sadeng & Livistonia sp. & 10 \\
\hline 26 & Palm Sirip Ikan & Livistonia decipiens & 7 \\
\hline 27 & Pinus & Pinus merkusii & 4 \\
\hline 28 & Sikat Botol & Callistemon citrianus & 1 \\
\hline \multirow[t]{2}{*}{29} & Trembesi & Samanea saman & 186 \\
\hline & Sub Total & & 992 \\
\hline
\end{tabular}


Lampiran 2. Identifikasi Vegetasi di RTH Cluster BGH (Sumber: Lapang)

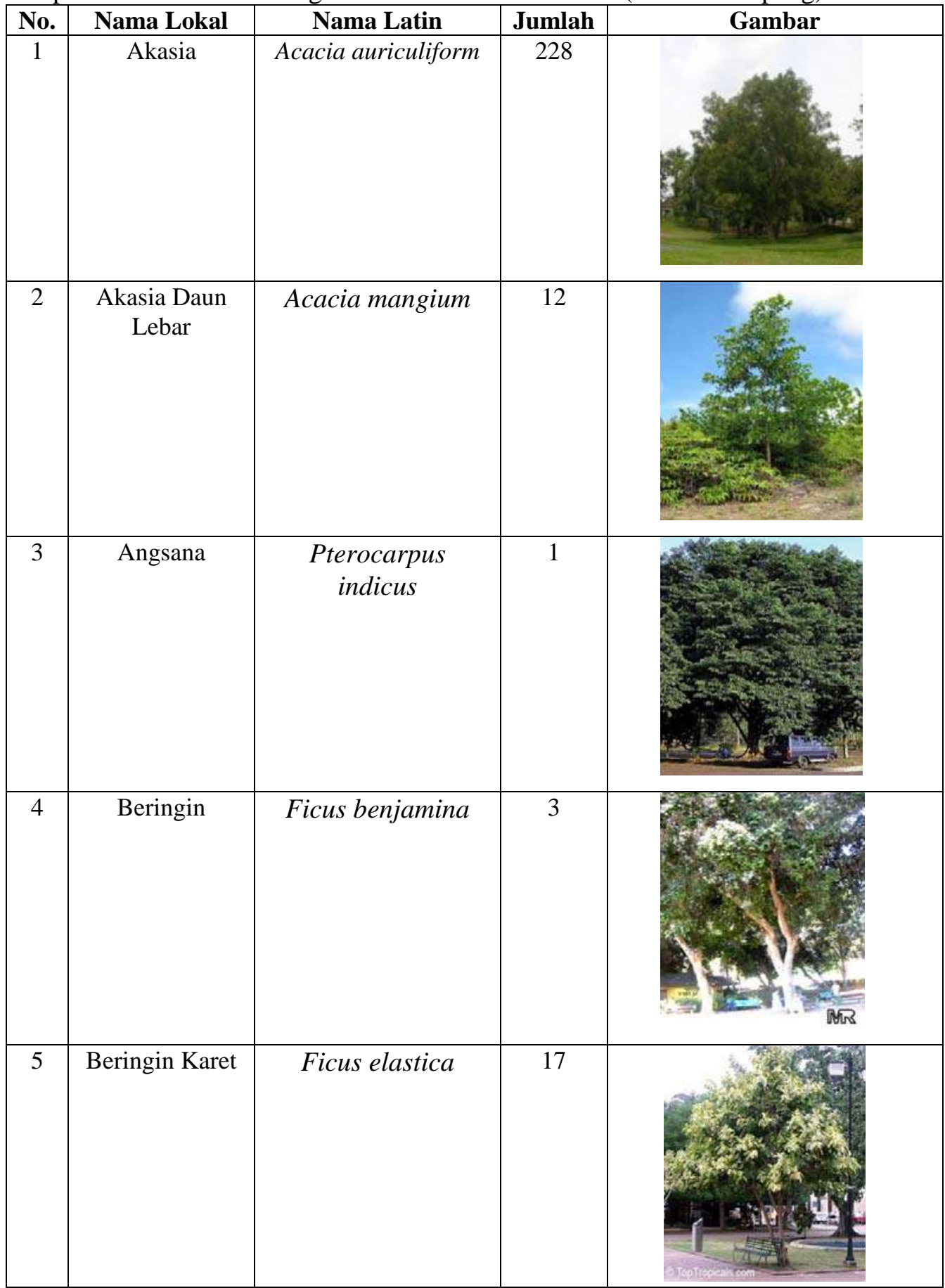


Lampiran 2. Lanjutan

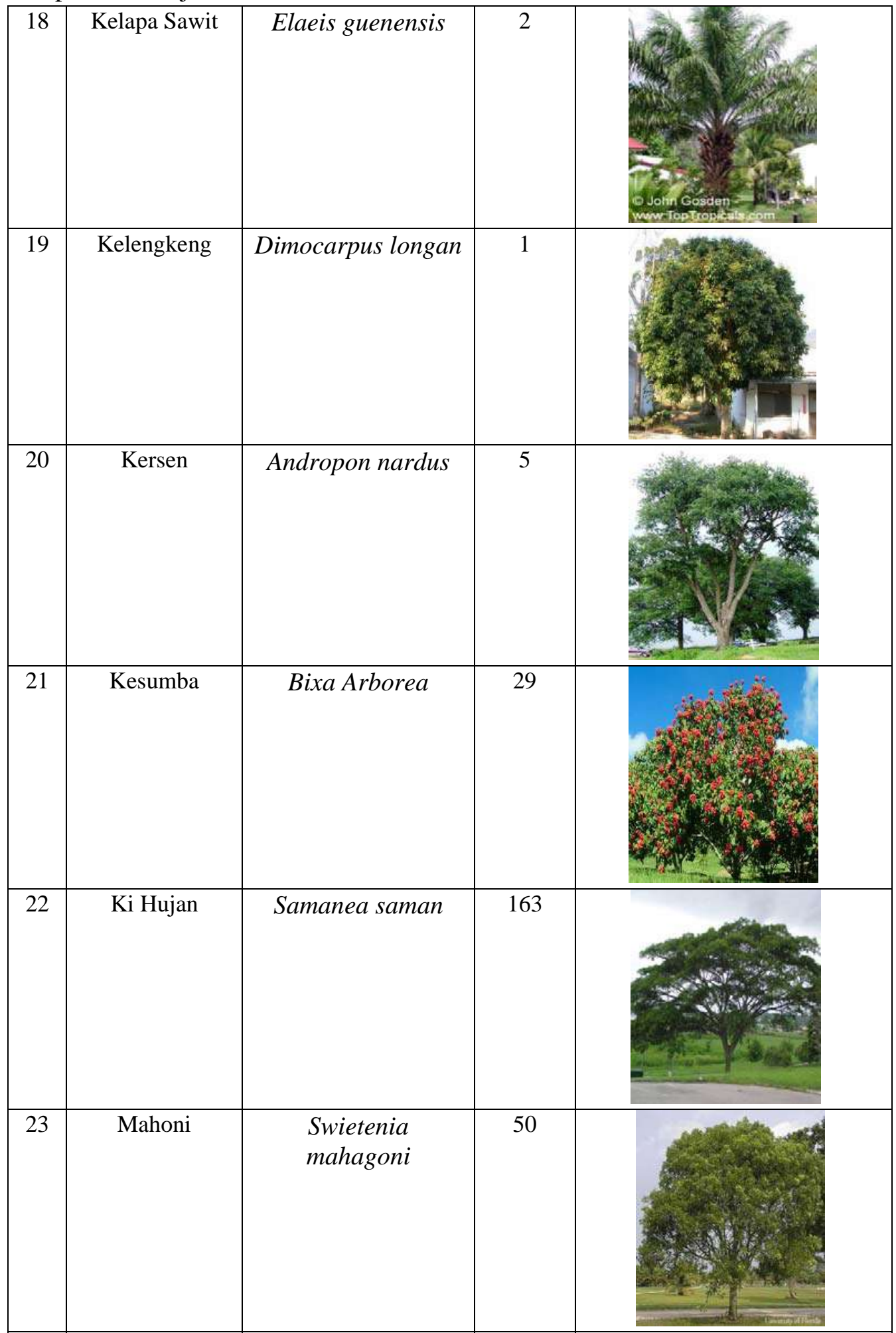


Lampiran 2. Lanjutan

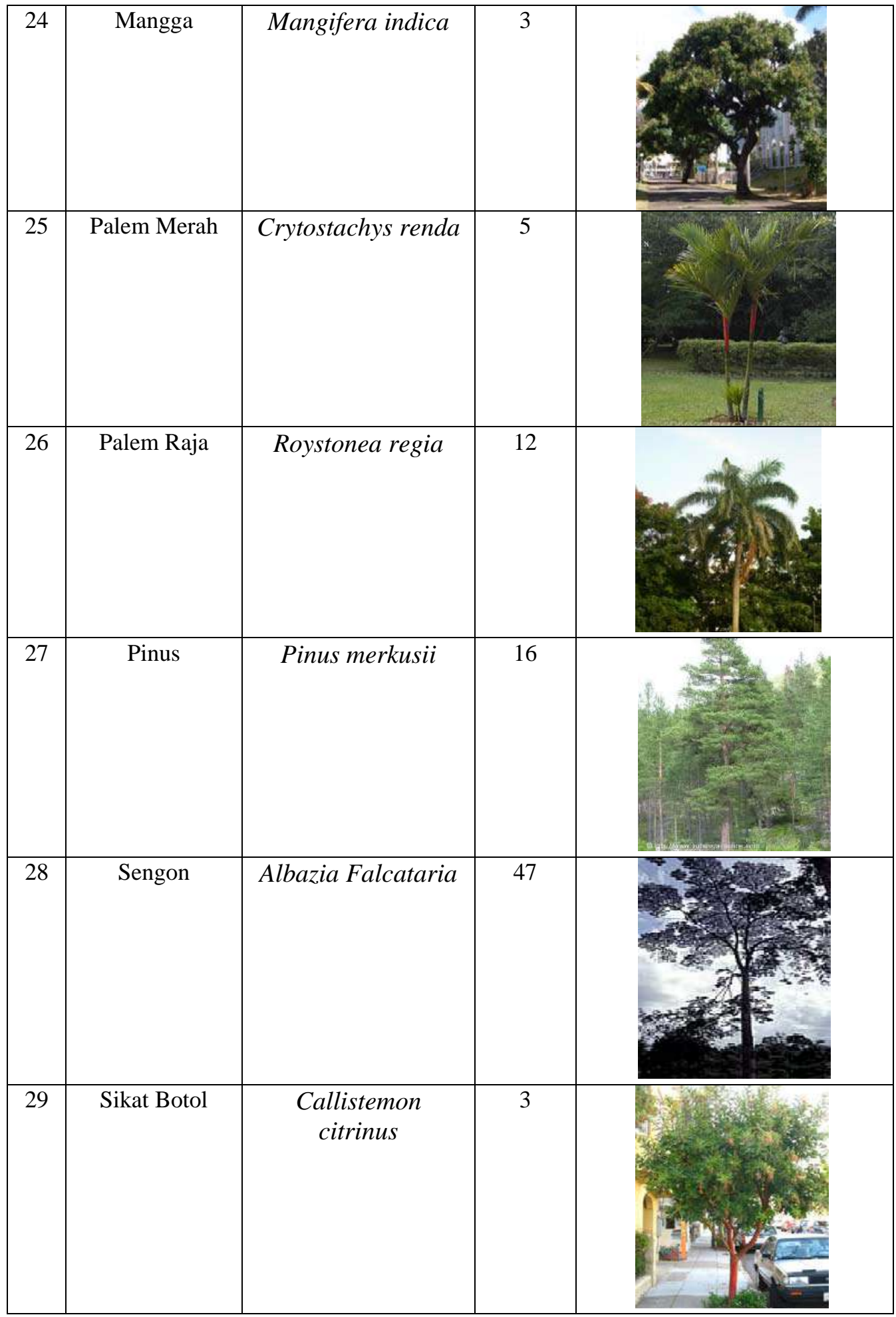

$\varepsilon$ 害它 
Lampiran 3. Data Kriteria Vegetasi di Lokasi Penanaman Berbeda (Sumber : Pengelola Sentul City)

\section{Fungsi Vegetasi}

Lokasi Penanaman

Contoh Tanaman

\begin{tabular}{|c|c|c|c|c|}
\hline Iklim Mikro & $\begin{array}{l}\text { Ruang Terbuka Hijau, } \\
\text { Sekitar Danau Teratai }\end{array}$ & $\begin{array}{l}\text { Kesumba } \\
\text { Asam Kranji } \\
\text { Kapuk Randu }\end{array}$ & $\begin{array}{l}\text { Bixa orellana } \\
\text { Pithecellobium dulce } \\
\text { Ceiba petandre }\end{array}$ & $\begin{array}{l}\text { Tajuk horisontal, buah } \\
\text { merah seperti rambut } \\
\text { Tajuk eksotis, ranting- } \\
\text { ranting menggantung } \\
\text { Tajuk rapat, percabangan } \\
\text { horisontal, buah } \\
\text { menggantung }\end{array}$ \\
\hline Peredam Angin & $\begin{array}{l}\text { Koridor Jalan Utama dan } \\
\text { Jalan Lingkungan }\end{array}$ & $\begin{array}{l}\text { Dadap Merah } \\
\text { Bungur } \\
\text { Beringin Karet } \\
\text { Bintaro }\end{array}$ & $\begin{array}{l}\text { Erythrina crista-galli } \\
\text { Lagerstromia indica } \\
\text { Ficus elastica } \\
\text { cerbera odollan }\end{array}$ & $\begin{array}{l}\text { Daun tebal hijau tua, } \\
\text { warna bunga merah } \\
\text { menyala } \\
\text { Tajuk horisontal, batang } \\
\text { berwarna krem bercak- } \\
\text { bercak putih, daun hijau, } \\
\text { bunga berwarna ungu } \\
\text { Ukuran daun besar, } \\
\text { warna bagian atas hijau } \\
\text { licin, bagian bawah da } \\
\text { berwarna kcoklatan } \\
\text { Batang berwarna abu, } \\
\text { daun agak memanjang, } \\
\text { buah berbentuk bulat } \\
\text { berwarna hijau muda }\end{array}$ \\
\hline Peneduh & Ruang Terbuka Hijau & Beringin & Ficus benjamina & Tajuk bulat, percabangan \\
\hline
\end{tabular}

Bentuk Fisik/Karakter
Nama Lokal

Nama Latin 
Lampiran 3. Lanjutan

\begin{tabular}{|c|c|c|c|c|}
\hline Peneduh & & $\begin{array}{l}\text { Bunga Kupu-Kupu } \\
\text { Kerai Payung } \\
\text { Biola Cantik } \\
\text { Sawo Kecik }\end{array}$ & $\begin{array}{l}\text { Bauhinia purpurea } \\
\text { Filicium decipiens } \\
\text { Ficus lyrata } \\
\text { Manilkara kauki }\end{array}$ & $\begin{array}{l}\text { rapat, daun kecil-kecil } \\
\text { berwarna hijau licin } \\
\text { Daun menyerupai bentuk } \\
\text { sayap kupu-kupu, warna } \\
\text { bunga putih } \\
\text { Tajuk bulat, daun kecil- } \\
\text { kecil dan sering rontok } \\
\text { Ukuran daun besar } \\
\text { menyerupai biola, daun } \\
\text { agak kasar } \\
\text { Tajuk kolumnar, } \\
\text { percabangan rendah, buah } \\
\text { berwarna merah }\end{array}$ \\
\hline Kontrol kebisingan & $\begin{array}{l}\text { Taman Budaya dan } \\
\text { Lingkungan Perumahan }\end{array}$ & $\begin{array}{l}\text { Mahoni } \\
\text { Pinus } \\
\text { Kecrutan }\end{array}$ & $\begin{array}{l}\text { Swietenia mahagoni } \\
\text { Pinus merkusii } \\
\text { Spathodea campanulata }\end{array}$ & $\begin{array}{l}\text { Tajuk tidak teratur, } \\
\text { percabangan ke atas dan } \\
\text { rimbun, efektif menyerap } \\
\text { polusi udara } \\
\text { Tajuk segitiga, berdaun } \\
\text { jarum, tumbuh baik di } \\
\text { tempat terbuka }\end{array}$ \\
\hline
\end{tabular}


Lampiran 4. Perhitungan Hygrometer

\begin{tabular}{|c|c|c|c|c|c|c|c|c|c|}
\hline \multirow{2}{*}{$\begin{array}{l}\text { Suhu } \\
\text { Kering }\end{array}$} & \multicolumn{9}{|c|}{$\begin{array}{l}\text { Kolom Hasil Selisih Angka Suhu Kering (TBK) dan Suhu Basah } \\
\text { (TBB) }\end{array}$} \\
\hline & 0 & 1 & 2 & 3 & 4 & 5 & 6 & 7 & 8 \\
\hline 40 & 100 & 94 & 88 & 82 & 76 & 71 & 66 & 61 & 56 \\
\hline 39 & 100 & 94 & 87 & 82 & 76 & 70 & 65 & 60 & 55 \\
\hline 38 & 100 & 94 & 87 & 81 & 75 & 70 & 64 & 59 & 54 \\
\hline 37 & 100 & 93 & 87 & 81 & 75 & 69 & 64 & 59 & 53 \\
\hline 36 & 100 & 93 & 87 & 81 & 75 & 69 & 63 & 58 & 53 \\
\hline 35 & 100 & 93 & 87 & 80 & 74 & 68 & 63 & 57 & 52 \\
\hline 34 & 100 & 93 & 86 & 80 & 74 & 68 & 62 & 56 & 51 \\
\hline 33 & 100 & 93 & 86 & 80 & 73 & 67 & 61 & 56 & 50 \\
\hline 32 & 100 & 93 & 86 & 79 & 73 & 66 & 61 & 55 & 49 \\
\hline 31 & 100 & 93 & 86 & 79 & 72 & 66 & 60 & 54 & 48 \\
\hline 30 & 100 & 92 & 85 & 78 & 72 & 65 & 59 & 53 & 47 \\
\hline 29 & 100 & 92 & 85 & 78 & 71 & 64 & 58 & 52 & 46 \\
\hline 28 & 100 & 92 & 85 & 77 & 70 & 64 & 57 & 51 & 45 \\
\hline 27 & 100 & 92 & 84 & 77 & 70 & 63 & 56 & 50 & 43 \\
\hline 26 & 100 & 92 & 84 & 76 & 69 & 62 & 55 & 48 & 42 \\
\hline 25 & 100 & 92 & 84 & 76 & 68 & 61 & 54 & 47 & 41 \\
\hline 24 & 100 & 91 & 83 & 75 & 68 & 60 & 53 & 46 & 39 \\
\hline 23 & 100 & 91 & 83 & 75 & 67 & 59 & 52 & 45 & 38 \\
\hline 22 & 100 & 91 & 82 & 74 & 66 & 58 & 50 & 43 & 36 \\
\hline 21 & 100 & 91 & 82 & 73 & 65 & 57 & 49 & 43 & 34 \\
\hline 20 & 100 & 91 & 81 & 73 & 64 & 56 & 48 & 40 & 32 \\
\hline 19 & 100 & 90 & 81 & 72 & 63 & 54 & 46 & 38 & 30 \\
\hline 18 & 100 & 90 & 80 & 71 & 62 & 53 & 44 & 36 & 28 \\
\hline 17 & 100 & 90 & 80 & 70 & 61 & 51 & 43 & 34 & 26 \\
\hline 16 & 100 & 89 & 79 & 69 & 59 & 50 & 41 & 32 & 23 \\
\hline 15 & 100 & 89 & 78 & 68 & 58 & 48 & 39 & 30 & 21 \\
\hline
\end{tabular}


Lampiran 5 . Data Suhu, Kelembaban Udara, dan Angin (Januari -Desember 2009) (Sumber: BMKG)

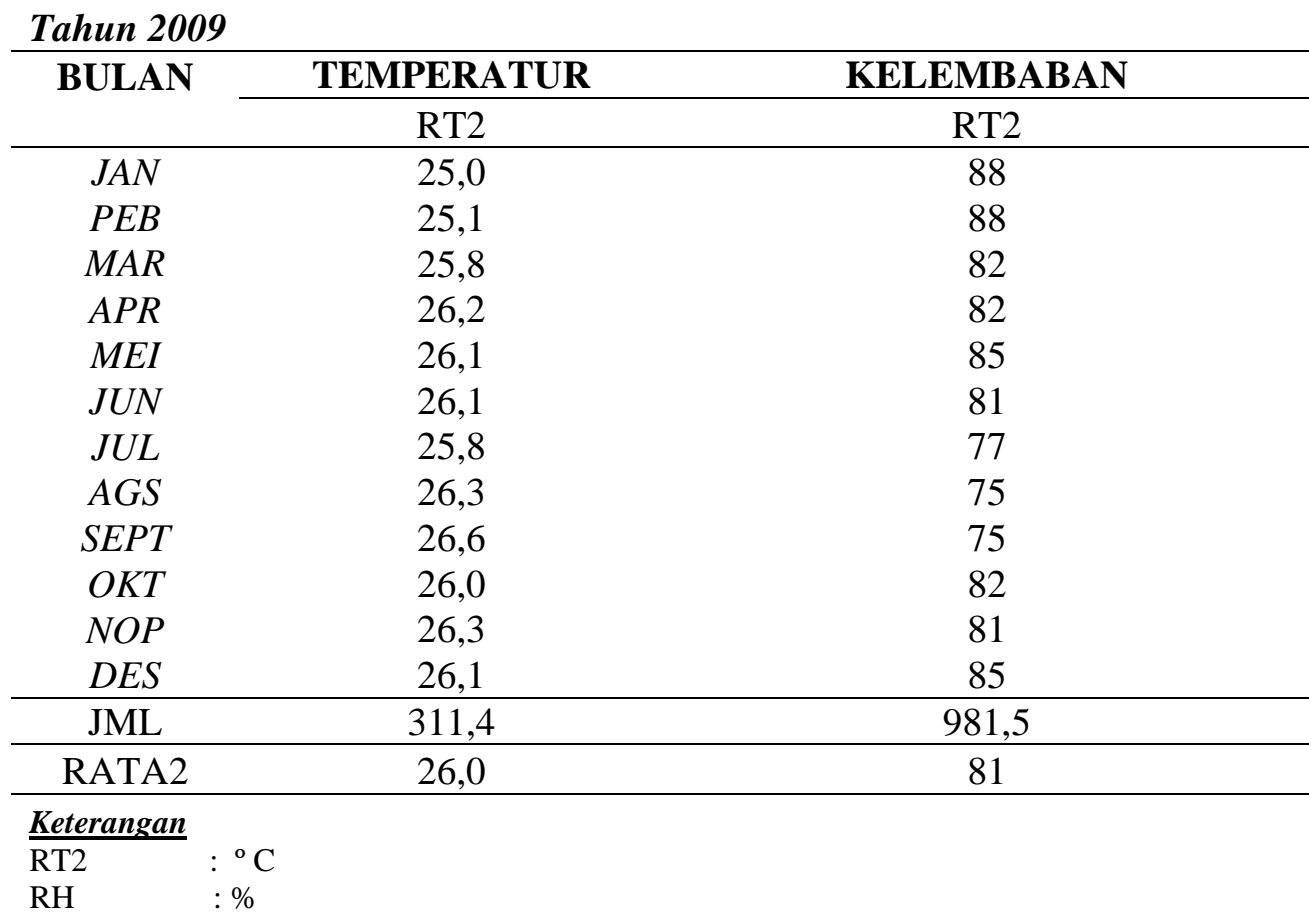

Tahun2008

\begin{tabular}{ccc}
\hline \multirow{2}{*}{ BULAN } & \multicolumn{2}{c}{ ANGIN } \\
\cline { 2 - 3 } & Kecepatan & Arah \\
\hline \hline JAN & 3,1 & $\mathrm{~W}$ \\
$P E B$ & 3,2 & $\mathrm{~W}$ \\
MAR & 2,5 & $\mathrm{~W}$ \\
$A P R$ & 2,3 & $\mathrm{~W}$ \\
MEI & 2,2 & $\mathrm{~W}$ \\
JUN & 2,0 & $\mathrm{~W}$ \\
JUL & 2,4 & $\mathrm{~W}$ \\
AGS & 2,2 & $\mathrm{~W}$ \\
SEPT & 2,6 & $\mathrm{~W}$ \\
OKT & 2,4 & $\mathrm{~W}$ \\
NOP & 2,8 & $\mathrm{~W}$ \\
DES & 2,8 & $\mathrm{~W}$ \\
\hline JML & 30,5 & \\
\hline RATA2 & 2,5 & \\
\hline
\end{tabular}

Keterangan

Kec. Angin
Tahun2009

\begin{tabular}{|c|c|c|}
\hline \multirow{2}{*}{ BULAN } & \multicolumn{2}{|l|}{ ANGIN } \\
\hline & Kecepatan & Arah \\
\hline$J A N$ & 2,9 & W \\
\hline PEB & 3,5 & W \\
\hline$M A R$ & 2,9 & W \\
\hline$A P R$ & 2,3 & W \\
\hline$M E I$ & 2,2 & W \\
\hline$J U N$ & 2,1 & W \\
\hline JUL & 2,4 & W \\
\hline$A G S$ & 2,4 & W \\
\hline SEPT & 2,7 & $\mathrm{~W}$ \\
\hline$O K T$ & 2,4 & W \\
\hline$N O P$ & 2,6 & W \\
\hline$D E S$ & 2,3 & W \\
\hline JML & 30,7 & \\
\hline RATA2 & 2,6 & \\
\hline
\end{tabular}


Lampiran 6. Skala Beaufort dan Kecepatan Angin

\begin{tabular}{|c|c|c|c|}
\hline $\begin{array}{c}\text { Skala } \\
\text { Beaufort }\end{array}$ & Tingkatan & $\begin{array}{c}\text { Kecepatan } \\
\text { (knot) }\end{array}$ & Tanda-tanda di darat \\
\hline 0 & Tenang & $<1$ & Tenang, asap mengepul vertikal \\
\hline 1 & Teduh & $1-3$ & Asap mengepul miring \\
\hline 2 & Sepoi lemah & $4-6$ & Terpaan angin terasa di muka \\
\hline 3 & Sepoi lembut & $7-10$ & $\begin{array}{l}\text { Daun-daun kecil di pohon bergerak, } \\
\text { bendera dapat berkibar }\end{array}$ \\
\hline 4 & Sepoi sedang & $11-16$ & $\begin{array}{l}\text { Debu dan kertas dapat terbang, } \\
\text { ranting pohon bergerak }\end{array}$ \\
\hline 5 & Sepoi segar & $17-21$ & $\begin{array}{l}\text { pohon-pohon kecil terlihat condong. } \\
\text { Genangan air di tanah terlihat } \\
\text { berombak kecil }\end{array}$ \\
\hline 6 & Sepoi kuat & $22-27$ & $\begin{array}{l}\text { Batang pohon terlihat bergerak; suara } \\
\text { berdesing dan kawat telepon dapat } \\
\text { terdengar }\end{array}$ \\
\hline 7 & $\begin{array}{l}\text { Angin ribut } \\
\text { lemah }\end{array}$ & $28-33$ & $\begin{array}{l}\text { Pohon-pohon bergerak; berjalan terasa } \\
\text { berat }\end{array}$ \\
\hline 8 & Angin ribut & $34-40$ & $\begin{array}{l}\text { Batang pohon dapat patah, sampai } \\
\text { pohon tumbang }\end{array}$ \\
\hline 9 & $\begin{array}{l}\text { Angin ribut } \\
\text { kuat }\end{array}$ & $41-47$ & $\begin{array}{l}\text { Dapat membawa kerusakan cerobong; } \\
\text { pot-pot beterbangan }\end{array}$ \\
\hline 10 & Badai & $48-55$ & $\begin{array}{l}\text { kerusakan lebih besar; tetapi di darat } \\
\text { jarang terjadi }\end{array}$ \\
\hline 11 & Badai amuk & $56-63$ & kerusakan berat; tetapi di darat jarang \\
\hline 12 & Topan & $>63$ & Hampir tidak pernah terjadi \\
\hline
\end{tabular}

